\title{
Critical evaluation of human health risks due to hydraulic fracturing in natural gas and petroleum production
}

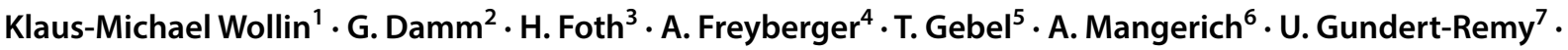 \\ F. Partosch ${ }^{8} \cdot$ C. Röhl ${ }^{9} \cdot$ T. Schupp ${ }^{10} \cdot$ Jan G. Hengstler ${ }^{11}$
}

Received: 6 February 2020 / Accepted: 26 March 2020 / Published online: 9 May 2020

(c) The Author(s) 2020

\begin{abstract}
The use of hydraulic fracturing (HF) to extract oil and natural gas has increased, along with intensive discussions on the associated risks to human health. Three technical processes should be differentiated when evaluating human health risks, namely (1) drilling of the borehole, (2) hydraulic stimulation, and (3) gas or oil production. During the drilling phase, emissions such as $\mathrm{NO}_{x}$, NMVOCs (non-methane volatile organic compounds) as precursors for tropospheric ozone formation, and $\mathrm{SO}_{x}$ have been shown to be higher compared to the subsequent phases. In relation to hydraulic stimulation, the toxicity of frac fluids is of relevance. More than 1100 compounds have been identified as components. A trend is to use fewer, less hazardous and more biodegradable substances; however, the use of hydrocarbons, such as kerosene and diesel, is still allowed in the USA. Methane in drinking water is of low toxicological relevance but may indicate inadequate integrity of the gas well. There is a great concern regarding the contamination of ground- and surface water during the production phase. Water that flows to the surface from oil and gas wells, so-called 'produced water', represents a mixture of flow-back, the injected frac fluid returning to the surface, and the reservoir water present in natural oil and gas deposits. Among numerous hazardous compounds, produced water may contain bromide, arsenic, strontium, mercury, barium, radioactive isotopes and organic compounds, particularly benzene, toluene, ethylbenzene and xylenes (BTEX). The sewage outflow, even from specialized treatment plants, may still contain critical concentrations of barium, strontium and arsenic. Evidence suggests that the quality of groundwater and surface water may be compromised by disposal of produced water. Particularly critical is the use of produced water for watering of agricultural areas, where persistent compounds may accumulate. Air contamination can occur as a result of several HF-associated activities. In addition to BTEX, $20 \mathrm{HF}$-associated air contaminants are group 1A or 1B carcinogens according to the IARC. In the U.S., oil and gas production (including conventional production) represents the second largest source of anthropogenic methane emissions. High-quality epidemiological studies are required, especially in light of recent observations of an association between childhood leukemia and multiple myeloma in the neighborhood of oil and gas production sites. In conclusion, (1) strong evidence supports the conclusion that frac fluids can lead to local environmental contamination; (2) while changes in the chemical composition of soil, water and air are likely to occur, the increased levels are still often below threshold values for safety; (3) point source pollution due to poor maintenance of wells and pipelines can be monitored and remedied; (4) risk assessment should be based on both hazard and exposure evaluation; (5) while the concentrations of frac fluid chemicals are low, some are known carcinogens; therefore, thorough, well-designed studies are needed to assess the risk to human health with high certainty; (6) HF can represent a health risk via long-lasting contamination of soil and water, when strict safety measures are not rigorously applied.
\end{abstract}

Keywords Hydraulic fracturing $\cdot$ Unconventional natural gas and oil production $\cdot$ Environmental pollution $\cdot$ Human health risk assessment $\cdot$ Epidemiological studies

Klaus-Michael Wollin

klaus-michael.wollin@t-online.de

Jan G. Hengstler

hengstler@ifado.de

Extended author information available on the last page of the article

\section{Introduction}

Hydraulic fracturing (HF) is widely used to enhance oil and gas extraction from source rock and low-permeability shale (U.S. EPA 2016a). This technique is based on the 
high-pressure injection of a mixture of water, propping agents and frac fluids into a wellbore, with the intention to cause small cracks in oil- or gas-containing deep-rock formations (Fig. 1). The cracks allow an improved flow of oil or gas from their natural reservoirs to the drilling site. HF is required to exploit oil or gas (shale oil or shale gas) from bituminous shale, the so-called 'non-conventional deposits'. In recent years, HF has become more economically viable because of the development of advanced horizontal drilling techniques in combination with multistage HF, which creates extended fracture networks to enhance the contact area between the rock matrix and the wellbore (Vidic et al. 2013). The U.S. Energy Information Administration (EIA) estimates that in 2018, U.S. dry shale gas production was about 20.95 trillion cubic feet (Tcf) $\left(593.24 \times 10^{9} \mathrm{~m}^{3}\right)$, and equal to about $69 \%$ of total U.S. dry natural gas production in 2018 (U.S. EIA 2019). The U.S. EIA's “Annual Energy Outlook 2019” predicted an increase of natural gas production as a result of the continued development of tight and shale resources which would account for nearly $90 \%$ of dry natural gas production by 2050 (U.S. EIA 2019). China's shale gas production is predicted to grow from 0.7 billion cubic feet per day (Bcf/day) $\left(19.82 \times 10^{6} \mathrm{~m}^{3} /\right.$ day $)$ in 2016 to $10 \mathrm{Bcf} /$ day $\left(283.17 \times 10^{6} \mathrm{~m}^{3} /\right.$ day) by 2030 and $19 \mathrm{Bcf} /$ day $\left(538.02 \times 10^{6} \mathrm{~m}^{3} /\right.$ day $)$ by 2040 (U.S. EIA 2017). China's natural gas production from other sources, such as coalbed methane, tight formations and more traditional natural gas reservoirs, is projected to increase more modestly, from $12 \mathrm{Bcf} /$ day $\left(339.80 \times 10^{6} \mathrm{~m}^{3} /\right.$ day $)$ in 2016 to $20 \mathrm{Bcf} /$ day $\left(566.34 \times 10^{6} \mathrm{~m}^{3} /\right.$ day $)$ by 2040 .
In Germany, HF has been used to produce gas for more than 4 decades. In Lower Saxony, the German state with the most extensive use of HF, 327 hydraulic stimulations and 148 drillings have been performed, most of which exploited tight gas at depths of at least 3000 m (BGR 2016). Compared to other European countries, Germany has the fourth and fifth largest resources of shale gas and shale oil, respectively. The technically recoverable shale gas resources range between 320 and 2030 billion $\mathrm{m}^{3}$ of natural gas at a depth of $1000-5000 \mathrm{~m}$. Including deposits between 500 and $1000 \mathrm{~m}$ deep, the total recoverable lean-burn gas quantities have increased to between 380 and 2340 billion $\mathrm{m}^{3}$.

The impact of HF on the environment is complex. With respect to human health hazards, the contamination of groundwater and its use as drinking water has been in the center of attention. Moreover, other issues have been raised, such as the high demand for water and land, the impact on biodiversity and landscape, contamination of air by emissions, induced seismic activity, and the greenhouse-gas balance. Due to the rapid development of shale gas extraction, especially in the USA, and the public debate about environmental consequences and human health hazards, possible adverse effects of HF on human health, environmental consequences and the legal frameworks have been discussed (Ewen et al. 2012; Meiners et al. 2012a, b; SRU 2013; Dannwolf et al. 2014; Kersting et al. 2015; U.S. EPA 2016a). The multifaceted topic of HF remains up-to-date against the background of the strong growth of use in the USA and China, the world's two largest economies. From a Public Health perspective, alone in the
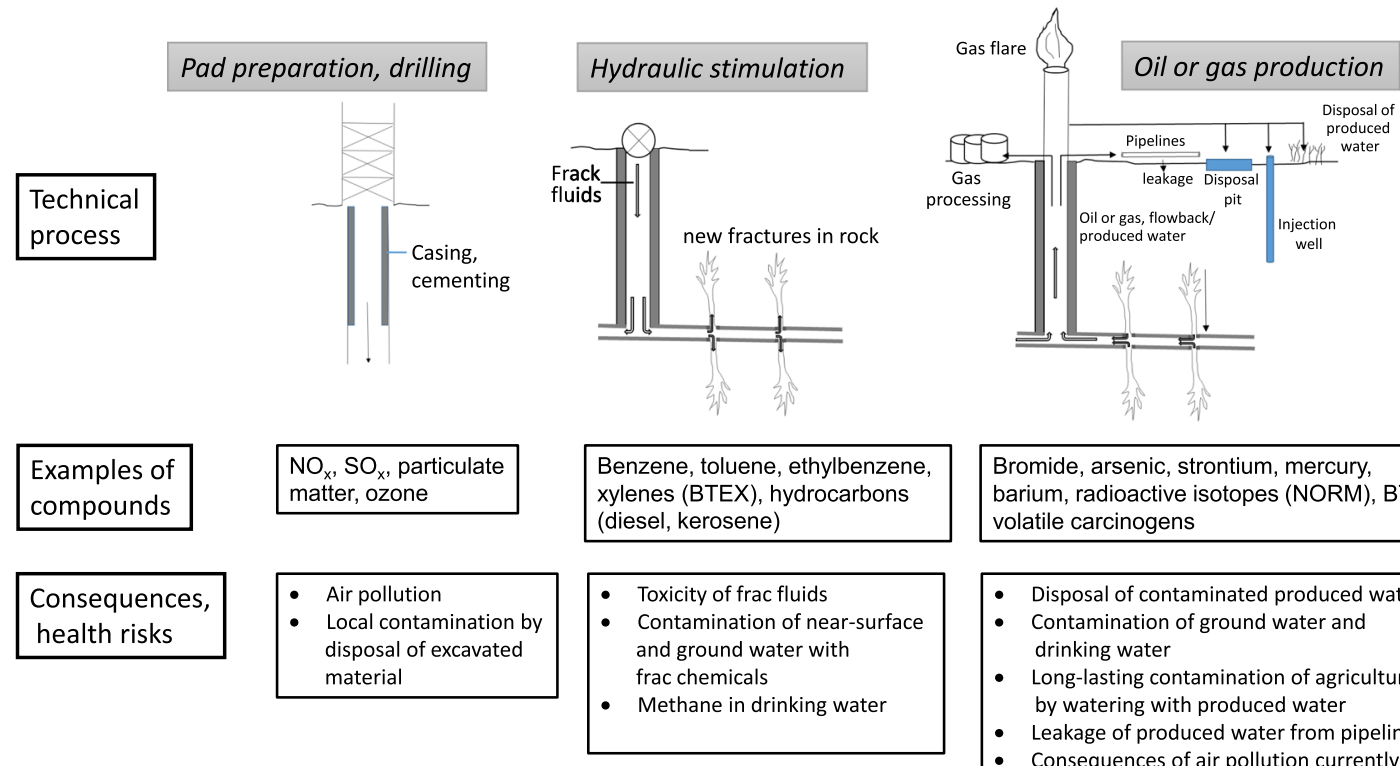

Bromide, arsenic, strontium, mercury, barium, radioactive isotopes (NORM), BTEX, volatile carcinogens

- $\begin{aligned} & \text { - } \text { Contaminasal of contaminated produced water } \\ & \text { drinking water }\end{aligned}$
- Long-lasting contamination of agricultural areas
by watering with produced water
- Leakage of produced water from pipelines
Consequences of air pollution currently unclear
(follow-up studies for airway diseases, and
hematological malignancies required)

Fig. 1 Hydraulic fracturing: the overall process 
USA $\sim 17$ million residents live within one mile of an active oil and/or gas well and are potentially exposed to pollution as a result of frac operations (U.S. EPA 2016a).

The present review focusses on human health hazards of HF. The technical procedures will be described only to an extent that is necessary to understand toxicological risks for humans. Further aspects, such as energy supply security, influence on ecosystems, biodiversity, landscape, greenhouse gas balance, and socio-economic factors, will not be addressed.

\section{The procedure of hydraulic fracturing}

The six basic steps of HF have already been comprehensively described (e.g., Cheremisinoff and Davletshin 2015; Gandossi and von Estorff 2015; Smith and Montgomery 2015; Ahmed and Meehan 2016; U.S. EPA 2016a) and involve (1) the identification of possible production sites (exploration); (2) site selection and construction of a drilling place; (3) drilling, casing and cementing; (4) hydraulic stimulation; (5) production; (6) dismantling of the drilling place and renaturation. Application of frac fluids requires the following processes: (i) removing large volumes of groundor surface water for the production of frac fluids-between 3 and 50 million L of water are pumped into each individual well (Vengosh et al. 2014; McLaughlin et al. 2016); (2) production of frac fluid, i.e., proppants and frac fluid additives are stored and mixed at the drilling site; (3) injection of frac fluids into the borehole, (4) storage and processing of the produced water; (5) disposal of the flow-back from the drilling site and produced water.

\section{Function and composition of frac fluids}

Frac fluids induce small cracks in the relevant rock targets and allow the transport of proppants into the cracks. Major components of frac fluids are the basic fluid, additives and proppants. Proppants mostly consist of unprocessed, specified quartz sand but high-strength ceramic, sintered bauxite or zirconium oxide may also be used (Barati and Liang 2014; U.S. EPA 2016a). The function of the frac fluid additives is to increase the viscosity of the fluid, and to reduce corrosion of the bore and microbial growth. Frac fluids can be water or water/gel based. Water-based systems dominate in current $\mathrm{HF}$, while alternatives constitute only $\sim 2 \%$ (U.S. EPA 2015). Water-based frac fluids (slickwater fluids) contain polymers to reduce friction and are used in reservoirs with low permeability, such as clay. Slickwater frac fluids are currently mostly used for the extraction of shale gas (Gandossi and von Estorff 2015). They have a lower viscosity than gel fluids and transport proppants less efficiently into the cracks; therefore, larger volumes of water and higher pressure are required. By contrast, gel fluids are used in the formation with a higher permeability. Despite the higher water consumption of slickwater fluids, they are more cost-effective, easier to produce and offer the possibility of water recycling.

Alternative frac fluids consist of foamed materials or emulsions that are generated by the use of nitrogen, carbon dioxide, hydrocarbons and methanol (Montgomery 2013; Saba et al. 2012; Gupta and Hlidek 2009; Gupta and Valkó 2007). Moreover, acid-based frac fluids are used for HF in carbonate formations without the addition of proppants. A particular challenge for $\mathrm{HF}$ is in rock formations where the injection of water reduces permeability. Here, non-waterbased fluids are used that consist of petroleum distillates and propane and, usually, further additives. The use of nonwater-based frac fluids has decreased in recent years due to the improvement of safety and health considerations and water-based techniques. Nevertheless, the use of hydrocarbons such as diesel or kerosene is still allowed according to the revised criteria of the U.S. EPA (2014). Therefore, typical compound groups in frac fluids are gelling agents, thickening agents, stabilizers of clay, biocides, solubilizers, viscosity modifiers, surface tension reducers, buffers, and anti-foam agents (Stringfellow et al. 2014, 2017a; Elsner and Hoelzer 2016; U.S. EPA 2016a; King and Durham 2015; Kahrilas et al. 2015). There are more than 1100 chemicals listed as potentially present in frac fluids (U.S. EPA 2011). The Tyndall Centre Manchester (2011) provides an overview of 260 additives, 750 chemicals and additional components that have been used in 2500 different frac fluids between 2005 and 2009. Chemicals used for HF in the USA are listed in FracFocus (http://fracfocus.org), which is organized by the US Groundwater Protection Council and the Interstate Oil and Gas Compact Commission (IOGCC). The British Columbia Oil and Gas Commission provides an analog platform (http://fracfocus.ca/en) in Canada. Indeed, compounds in frac fluids are increasingly made public (International Association of Oil and Gas Producers (IOGP) 2017; FracFocus 3.0 2020; Cuadrilla 2017). Chemicals used in Germany are listed on the website of the 'Bundesverband Erdgas, Erdöl und Geoenergie e. V.' (BVEG 2017). A comprehensive list of frac additives is also available in Meiners et al. (2012a, b). An overview of frequently used frac fluid chemicals and their function in the fluid is given in Table 1.

A similar compilation has been published, comprising 35 chemicals present in at least $10 \%$ of frac fluids (U. S. EPA 2016a). Besides chemicals listed in Table 1, this compilation includes the following substances and compound groups: quartz, sodium chloride, mineral oil, naphthalene, 2,2-dibromo-3-nitrilopropionamide, phenolic resins, hexamethylenetetramine, 1,2,4-trimethylbenzene, benzalkonium chloride, 4-nonylphenol (branched, ethoxylated, polymer), formic acid, sodium chlorite, tetrakis (hydroxymethyl), phosphonium sulfate $(2: 1)$, polyethylene glycol, ammonium 
Table 1 Frac fluid additives, their function in the fluid and corresponding chemicals (U.S. EPA 2016a, modified)

\begin{tabular}{|c|c|c|}
\hline Additive & Function & $\begin{array}{l}\text { Chemicals reported in } 20 \% \text { or more of disclosures in the EPA } \\
\text { FracFocus } 1.0 \text { project database for given additive (U.S. EPA } \\
2015)^{\mathrm{a}}\end{array}$ \\
\hline (Inorganic) Acid & $\begin{array}{l}\text { Dissolves cement, minerals, and clays to reduce clogging of } \\
\text { the pore space }\end{array}$ & Hydrochloric acid \\
\hline Biocide & $\begin{array}{l}\text { Controls or eliminates bacterial growth, which can be } \\
\text { present in the base fluid and may have detrimental effects } \\
\text { on the long-term well productivity }\end{array}$ & Glutaraldehyde; 2,2-dibromo-3-nitrilopropionamide \\
\hline Breaker & $\begin{array}{l}\text { Reduces the designed increase in viscosity of specialized } \\
\text { treatment fluids such as gels and foams after the proppant } \\
\text { has been placed and flow-back commences to clean up } \\
\text { the well }\end{array}$ & Peroxydisulfuric acid diammonium salt \\
\hline Clay control & $\begin{array}{l}\text { Prevents the swelling and migration of formation clays that } \\
\text { otherwise react to water-based fluids }\end{array}$ & Choline chloride \\
\hline Corrosion inhibitor & $\begin{array}{l}\text { Protects the iron and steel components in the wellbore and } \\
\text { treating equipment from corrosive fluids }\end{array}$ & Methanol; propargyl alcohol; isopropanol \\
\hline Crosslinker & $\begin{array}{l}\text { Increases the viscosity of base gel fluids by connecting } \\
\text { polymer molecules }\end{array}$ & Ethylene glycol; potassium hydroxide; sodium hydroxide \\
\hline Emulsifier & $\begin{array}{l}\text { Facilitates the dispersion of one immiscible fluid into } \\
\text { another by reducing the interfacial tension between the } \\
\text { two liquids to achieve stability }\end{array}$ & $\begin{array}{l}\text { Polyoxyethylene(10)nonylphenyl ether; methanol; nonyl } \\
\text { phenol ethoxylate }\end{array}$ \\
\hline Foaming agent & Generates and stabilizes foam fracturing fluids & $\begin{array}{l}\text { 2-Butoxyethanol; nitrogen, liquid; isopropanol; methanol; } \\
\text { ethanol }\end{array}$ \\
\hline Friction reducer & $\begin{array}{l}\text { Reduces the friction pressures experienced when pumping } \\
\text { fluids through tools and tubulars in the wellbore }\end{array}$ & Hydrotreated light petroleum distillates \\
\hline Gelling agent & $\begin{array}{l}\text { Increases fracturing fluid viscosity allowing the fluid to } \\
\text { carry more proppant into the fractures and to reduce fluid } \\
\text { loss to the reservoir }\end{array}$ & Guar gum; hydrotreated light petroleum distillates \\
\hline Iron control agent & $\begin{array}{l}\left.\text { Controls the precipitation of iron compounds (e.g., } \mathrm{Fe}_{2} \mathrm{O}_{3}\right) \\
\text { from solution }\end{array}$ & Citric acid \\
\hline Nonemulsifier & $\begin{array}{l}\text { Separates problematic emulsions generated within the } \\
\text { formation }\end{array}$ & Methanol; isopropanol; nonyl phenol ethoxylate \\
\hline $\mathrm{pH}$ control & $\begin{array}{l}\text { Regulates the } \mathrm{pH} \text { of a solution by either inducing a change } \\
\text { (pH adjuster) or stabilizing and resisting change (buffer) } \\
\text { to achieve desired qualities }\end{array}$ & $\begin{array}{l}\text { Carbonic acid, dipotassium salt; potassium hydroxide; } \\
\text { sodium hydroxide; acetic acid }\end{array}$ \\
\hline Resin curing agents & $\begin{array}{l}\text { Lowers the curable resin-coated proppant activation tem- } \\
\text { perature when bottom hole temperatures are too low to } \\
\text { thermally activate bonding }\end{array}$ & $\begin{array}{l}\text { Methanol; nonyl phenol ethoxylate; isopropanol; alcohols, } \\
\text { C12-14-secondary, ethoxylated }\end{array}$ \\
\hline Scale inhibitor & $\begin{array}{l}\text { Controls or prevents scale deposition in the production } \\
\text { conduit or completion system }\end{array}$ & Ethylene glycol; methanol \\
\hline Solvent & $\begin{array}{l}\text { Controls the wettability of contact surfaces or prevents or } \\
\text { breaks emulsions }\end{array}$ & Hydrochloric acid \\
\hline
\end{tabular}

${ }^{\mathrm{a}}$ This compilation considers 32,885 frac fluid recipes including 615,436 individual components

chloride and sodium persulfate. Methanol represents the most frequently mentioned chemical, present in approximately $72 \%$ of all frac fluids.

Some chemicals are added to frac fluids as tracers to control the efficiency of injection into rock formations (U.S. EPA 2016a) and to detect possible contaminations of the environment (Kurose 2014). These tracers include thiocyanates, fluorobenzoic acids, alkyl esters, and radioactive tracers such as titrated water or methanol. Due to the multitude of applied chemicals and different requirements depending on the specific geological conditions, a general recipe of all frac fluids is not available. The composition of frac fluids is highly variable. Furthermore, the application of chemicals changes rapidly since companies are constantly optimizing the processes. A trend is to use fewer and less hazardous chemicals (Gandossi and von Estorff 2015; Wang and Fan 2015; Kassner 2016; Halliburton 2017; Schlumberger 2017). The use of nanomaterials in frac fluids is still at a more basic level of research and development (Gottardo et al. 2016). While publication of the components of frac fluids in registers such as 
FracFocus 3.0 was previously performed on a voluntary basis, it is a legally binding duty in Germany since 2016.

Chemical transformation processes of frac fluid components are not well investigated and only scarce information is available. It is likely that certain chemicals, e.g., oxidants, undergo chemical reactions in the subsurface considering the high temperatures of $50-100{ }^{\circ} \mathrm{C}$ at depths of $1000-2500 \mathrm{~m}$, the high pressure and high salinity (Hoelzer et al. 2016). These chemical reaction products can be expected to appear in flow-back and produced water; however, their identity has not yet been systematically studied.

\section{Consumption of water and frac fluids}

Consumption of $8000-100,000 \mathrm{~m}^{3}$ water per unconventional well have been reported for six shale gas plays in the period between 2000 and 2011 (Vengosh et al. 2014). A representative study for major shale gas plays in Texas estimated the water consumption of 14,900 horizontal drilling operations in the Barnett shale, 390 in the Haynesville Formation and 1040 in the Eagle Ford Formation (Nicot and Scanlon 2012). During the 2009-6/2011 period, median water use per horizontal well was $10,600 \mathrm{~m}^{3}, 21,500 \mathrm{~m}^{3}$, and $16,100 \mathrm{~m}^{3}$ in the three areas, respectively. In another study, by fitting a normal distribution to freshwater withdrawal volumes, an average water consumption was estimated to be $15,000 \mathrm{~m}^{3}$ per single well in the Marcellus Shale Formation in Pennsylvania. Based on well completion reports submitted to the Pennsylvania Department of Environmental Protection (PADEP) in 2010 , it is indicated that $3500-26,000 \mathrm{~m}^{3}$ is required to hydraulically fracture a single well (Jiang et al. 2014). Using published scientific literature data from 2010 to 2014, water demand of 8000-19,000 $\mathrm{m}^{3}$ per well lifespan was estimated for a Polish shale gas production site (Vandecasteele et al. 2015). Data from Germany range from 37 to $4040 \mathrm{~m}^{3}$ water/ frac and consumption of additives of $615-274,764 \mathrm{~kg} / \mathrm{frac}$ (Meiners et al. 2012a, b). On the basis of modeling future HF operations in the USA in two scenarios of drilling rates, Kondash et al. (2018) projected cumulative water use and flow-back/produced water volumes to increase by up to 50 -fold in unconventional gas-producing regions and up to 20-fold in unconventional oil-producing regions between 2018 and 2030, assuming that the growth of water use matches current growth rates of HF production.

A relatively new aspect is to reuse the flow-back/production water. After high-pressure pumping of frac fluids into rock formations, the injected fluid returns to the surface via the borehole. Initially, the fraction of frac fluid is higher compared to formation water, the natural layer of water inside gas or oil reservoirs. Later, the fraction of frac fluid declines (NYSDEC 2011) and the production water consists predominantly of formation water. In principle, production water can be recycled to reduce the need for freshwater and chemicals (Leiming et al. 2016). Despite the advantages of this method, according to data from ten states in the USA (U.S. EPA 2016a), the fraction of recycled frac fluids by reusing production water is only about $5 \%$.

\section{Toxicity of frac fluids}

The public discussion on HF has focused predominantly on the hazardous substances present in frac fluids. In the $\mathrm{EU}$, the classification of the applied chemicals is performed according to European chemicals legislation (Gottardo et al. 2013; COM 2014). The CLP Regulation (classification, labeling and packaging of substances and mixtures) (Regulation (EC) No. 272/2008) is the basis of classification and labeling for the required technical dossiers; it comprises ten health hazard classes (Table 2) and 16 physio-chemical hazard classes, as well as a class for environmental hazards.

Two questions are particularly relevant when considering the hazard of chemicals used for HF: (a) What are the hazard characteristics of the individual compounds? (b) Do the applied frac fluid mixtures belong to the categories 'hazardous for human health' or 'hazardous to the environment' according to chemicals legislation? With respect to (a), frac fluids have been shown to contain hazardous compounds according to the GHS/CLP. These regulations are binding concerning transport, storage and use of the chemicals. Several comprehensive reviews are available which provide an overview of the classification of chemicals in frac fluids (Meiners et al. 2012a, b; Stringfellow et al. 2014; Elsner and Hoelzer 2016; Xu et al. 2019). Several compounds in frac fluids, such as biocides, have been classified as hazardous and are also used in consumer products. A well-known example is the biocide Kathon CG (CAS RN 55965-84-9), a mixture of 5-chloro-2-methyl-2H-isothiazole-3-on (C(M) IT) and 2-methyl-2H-isothiazole-3-on (MIT) at a ratio of 3:1. C(M)IT/MIT (3:1) has been approved by Commission Implementing Regulation (EU) 2016/131 of 1 February

Table 2 Classification of health hazards (Regulation 1272/2008/EC, Part 3 of Annex I)

\begin{tabular}{ll}
\hline Hazard class & Hazard class \\
\hline Acute toxicity & Carcinogenicity \\
Skin corrosion/irritation & Reproductive toxicity \\
Serious eye damage/eye irritation & Specific target organ \\
& toxicity-single \\
& exposure \\
Respiratory or skin sensitization & Specific target organ \\
& toxicity-repeated \\
& exposure \\
Germ cell mutagenicity & Aspiration hazard \\
\hline
\end{tabular}


2016 (COM 2016) to be used, e.g., in private area and public health area disinfectants and other biocidal products, and food and feed area disinfectants. In 2018, C(M)IT/MIT has been classified more strictly as hazard category 2 regarding acute toxicity after inhalation and dermal exposure. Furthermore, the issue of skin and eye irritation has also been comprehensively addressed (COM 2018) (Table 3).

Classification of compounds frequently used in frac fluids according to CLP is given in Table 4. The listed chemicals were present in at least $20 \%$ of all frac fluids listed in the U.S. EPA FracFocus 1.0 project database (U.S. EPA 2015, 2016a, Appendix C, Table C-2). This classification only informs about the intrinsic toxicity (hazard) of the compounds; however, conclusions with respect to health risks require additional information about exposure scenarios. Elements of a hazard-based approach in legal requirements of hydrofracking can be found in German water law: frac fluid mixtures are only permitted if they are classified as 'not hazardous to water' or 'low hazardous to water'.

A general problem which can arise during risk evaluation of frac fluids is given by the sometimes imprecise or missing description of their chemical composition and the chemical identity of individual compounds (Elsner et al. 2015) and/or the lack of toxicological data for the classification of individual frac chemicals as well as frac fluid mixtures.
Compared to the information available for individual frac chemicals, only little is known about complete frac fluid mixtures. Exceptions are self-classifications by users (e.g., ExxonMobile 2017). Risk assessment of frac fluids should refer to the total (finally applied) mixture, including the basic fluid, specific additives and proppants; this mixture should be evaluated based on the ratio of individual compounds of the entire volume (Regulation (EC) No 1272/2008 (CLP), article 2, 2008). In contrast to this regulation, some authors assessed only specific mixtures of additives and not the complete frac fluid. Using this procedure, Meiners et al. $(2012 \mathrm{a}, \mathrm{b})$ concluded that six of 88 analyzed additive mixtures should be classified as toxic, six as dangerous to the environment, 25 as harmful to human health, 14 as irritating, 12 as corrosive, and 27 as non-hazardous. However, in the finally used (complete) frac fluids, the concentrations of these compounds or mixtures of additives are so low that thresholds of the Regulation (EC) no. 1272/2008 (CLP) (2008) are usually not exceeded. Therefore, in many cases, the complete frac fluid mixtures can be classified as nonhazardous to human health (Ewers et al. 2013; Gordalla et al. 2013). Self-classifications of ExxonMobile (2017) came to the conclusion that the total fluid is weakly hazardous to water and not hazardous to the environment. According to

Table 3 Classification of reaction mass of 5-chloro-2-methyl-2H-isothiazol-3-one and 2-methyl-2H-isothiazol-3-one (3:1) and 2-methylisothiazol-3(2H)-one

\begin{tabular}{|c|c|c|}
\hline Chemical name & Hazard class and category code(s) & Hazard statement code(s) \\
\hline \multirow{9}{*}{$\begin{array}{l}\text { Reaction mass of 5-chloro-2-methyl-2H-isothiazol- } \\
\text { 3-one and 2-methyl-2H-isothiazol-3-one }(3: 1)^{\mathrm{a}}\end{array}$} & Acute Tox. 3 & H301 (toxic if swallowed) \\
\hline & Acute Tox. 2 & H310 (fatal in contact with skin) \\
\hline & Acute Tox. 2 & H330 (fatal if inhaled) \\
\hline & Skin Corr. 1C & H314 (causes severe skin burns and eye damage) \\
\hline & Skin Sens. 1A & H317 (may cause an allergic skin reaction) \\
\hline & Skin Irrit. 2 & H315 (causes skin irritation) \\
\hline & Eye Irrit. 2 & H319 (causes serious eye irritation) \\
\hline & Aquatic Acute 1 & H400 (very toxic to aquatic life) \\
\hline & Aquatic chronic 1 & $\begin{array}{l}\text { H410 (very toxic to aquatic life with long-lasting } \\
\text { effects) }\end{array}$ \\
\hline \multirow[t]{8}{*}{ 2-Methylisothiazol-3(2H)-one ${ }^{\mathrm{a}}$} & Acute Tox. 2 & H330 (fatal if inhaled) \\
\hline & Acute Tox. 3 & H311 (toxic in contact with skin) \\
\hline & Acute Tox. 3 & H301 (toxic if swallowed) \\
\hline & Skin Corr. 1B & H314 (causes severe skin burns and eye damage) \\
\hline & Eye Dam. 1 & H318 (causes serious eye damage) \\
\hline & Skin Sens. 1A & H317 (may cause an allergic skin reaction) \\
\hline & Aquatic Acute 1 & H400 (very toxic to aquatic life) \\
\hline & Aquatic Chronic 1 & $\begin{array}{l}\text { H410 (very toxic to aquatic life with long-lasting } \\
\text { effects) }\end{array}$ \\
\hline
\end{tabular}

Entry in Annex VI, Regulation CLP

${ }^{a}$ 13th Adaptation to Technical Progress (ATP) (COMMISSION REGULATION (EU) 2018/1480 of 4 October 2018) 
Table 4 Classification of commonly used frac chemicals (according to U.S. EPA 2016a) in accordance with the requirements of the CLP Regulation

\begin{tabular}{|c|c|c|c|}
\hline \multirow[t]{2}{*}{ International chemical identification } & \multirow[t]{2}{*}{ CAS RN } & \multicolumn{2}{|l|}{ Classification } \\
\hline & & $\begin{array}{l}\text { Hazard class and } \\
\text { category code(s) }\end{array}$ & $\begin{array}{l}\text { Hazard state- } \\
\text { ment code(s) }\end{array}$ \\
\hline 2,2-Dibromo-3-nitrilopropionamide ${ }^{a}$ & $10,222-01-2$ & & \\
\hline 2-Butoxyethanol & $111-76-2$ & $\begin{array}{l}\text { Acute Tox. } 4 \\
\text { Acute Tox. } 4 \\
\text { Acute Tox. } 4 \\
\text { Eye Irrit. } 2 \\
\text { Skin Irrit. } 2\end{array}$ & $\begin{array}{l}\text { H332 } \\
\text { H312 } \\
\text { H302 } \\
\text { H319 } \\
\text { H315 }\end{array}$ \\
\hline Prop-2-yn-1-ol; propargyl alcohol & $107-19-7$ & $\begin{array}{l}\text { Flam. Liq. } 3 \\
\text { Acute Tox. } 3 \\
\text { Acute Tox. } 3 \\
\text { Acute Tox. } 3 \\
\text { Skin Corr. 1B } \\
\text { Aquatic Chronic } 2\end{array}$ & $\begin{array}{l}\text { H226 } \\
\text { H331 } \\
\text { H311 } \\
\text { H301 } \\
\text { H314 } \\
\text { H411 }\end{array}$ \\
\hline Diammonium peroxodisulfate; ammonium persulfate & $7727-54-0$ & $\begin{array}{l}\text { Ox. Sol. } 3 \\
\text { Acute Tox. } 4 \\
\text { Eye Irrit. } 2 \\
\text { STOT SE } 3 \\
\text { Skin Irrit. } 2 \\
\text { Resp. Sens. } 1 \\
\text { Skin Sens. } 1\end{array}$ & $\begin{array}{l}\text { H272 } \\
\text { H302 } \\
\text { H319 } \\
\text { H335 } \\
\text { H315 } \\
\text { H334 } \\
\text { H317 }\end{array}$ \\
\hline Choline chloride ${ }^{\mathrm{b}}$ & $67-48-1$ & & \\
\hline Acetic acid & $64-19-7$ & $\begin{array}{l}\text { Flam. Liq. } 3 \\
\text { Skin Corr. 1A }\end{array}$ & $\begin{array}{l}\mathrm{H} 226 \\
\mathrm{H} 314\end{array}$ \\
\hline Ethanol; ethyl alcohol & $64-17-5$ & Flam. Liq. 2 & H225 \\
\hline Alcohols, C12-14-secondary, ethoxylated ${ }^{\mathrm{b}}$ & $84,133-50-6$ & & \\
\hline Ethanediol; ethylene glycol & $107-21-1$ & Acute Tox. 4 & H302 \\
\hline Liquid nitrogen ${ }^{c}$ & $7727-37-9$ & & \\
\hline Glutaral; glutaraldehyde; 1,5 -pentanedial & $111-30-8$ & $\begin{array}{l}\text { Acute Tox. } 3 \\
\text { Acute Tox. } 3 \\
\text { Skin Corr. 1B } \\
\text { Resp. Sens. 1 } \\
\text { Skin Sens. 1 } \\
\text { Aquatic Acute } 1\end{array}$ & $\begin{array}{l}\text { H331 } \\
\text { H301 } \\
\text { H314 } \\
\text { H334 } \\
\text { H317 } \\
\text { H400 }\end{array}$ \\
\hline Guar gum, propoxylated ${ }^{\mathrm{b}}$ & $39,421-75-5$ & & \\
\hline $\begin{array}{l}\text { Distillates (petroleum), hydrotreated light; kerosine—unspec- } \\
\text { ified; }\end{array}$ & $64,742-47-8$ & Asp. Tox. 1 & H304 \\
\hline Propan-2-ol; isopropyl alcohol; Isopropanol & $67-63-0$ & $\begin{array}{l}\text { Flam. Liq. } 2 \\
\text { Eye Irrit. } 2 \\
\text { STOT SE } 3\end{array}$ & $\begin{array}{l}\mathrm{H} 225 \\
\mathrm{H} 319 \\
\mathrm{H} 336\end{array}$ \\
\hline Potassium carbonate $^{\mathrm{b}}$ & $\begin{array}{l}584-08-7 \\
6381-79-9 \text { (ses- } \\
\text { quihydrate }\end{array}$ & & \\
\hline Potassium hydroxide; caustic potash & $1310-58-3$ & $\begin{array}{l}\text { Acute Tox. } 4 \\
\text { Skin Corr. 1A }\end{array}$ & $\begin{array}{l}\mathrm{H} 302 \\
\mathrm{H} 314\end{array}$ \\
\hline Methanol & $67-56-1$ & $\begin{array}{l}\text { Flam. Liq. } 2 \\
\text { Acute Tox. } 3 \\
\text { Acute Tox. } 3 \\
\text { Acute Tox. } 3 \\
\text { STOT SE } 1\end{array}$ & $\begin{array}{l}\text { H225 } \\
\text { H331 } \\
\text { H311 } \\
\text { H301 } \\
\text { H370 }\end{array}$ \\
\hline Sodium hydroxide; caustic soda & $1310-73-2$ & Skin Corr. 1A & H314 \\
\hline Polyethylene glycol nonylphenyl ether ${ }^{d}$ & $9016-45-9$ & & \\
\hline Hydrochloric acid & $231-595-7$ & $\begin{array}{l}\text { Skin Corr. 1B } \\
\text { STOT SE } 3\end{array}$ & $\begin{array}{l}\mathrm{H} 314 \\
\mathrm{H} 335\end{array}$ \\
\hline Citric acid $^{\mathrm{b}}$ & 77-92-9 & & \\
\hline
\end{tabular}

The listed chemicals were present in at least $20 \%$ of all frac fluids listed in the U.S. EPA FracFocus 1.0 project database (U.S. EPA 2016a, Appendix C, Table C-2)

${ }^{a}$ In: LIST OF PENDING ARTICLE 95(1) APPLICATIONS. Prepared as of 15 December 2015. ' Notified classification and labeling according to CLP criteria. ${ }^{\mathrm{c}}$ Not classified. ${ }^{\mathrm{d}}$ Committee for Risk Assessment (RAC) Opinion on an Annex XV dossier proposing restrictions on Nonylphenol and Nonylphenol ethoxylates: "NONYLPHENOL AND NONYLPHENOLETHOXYLATES IN TEXTILES" 
this assessment, labeling of the considered frac fluids would not be necessary (ExxonMobile 2017).

Another approach for the assessment of risks for health and ecological impacts by constituents of the frac fluid was introduced by Bergmann et al. (2014). The authors defined a risk quotient by dividing the substance's concentration in the frac fluid by an assessment value. The assessment values correspond to threshold values for groundwater (LAWA 2017), guidance values for drinking water, or precautionary values of drinking water for substances that cannot (or can only partially) be toxicologically assessed (Dieter 2014). If a compound has a risk quotient $<1$, no risk can be expected, while a risk quotient $\geq 1$ suggests a possibility of increased risk. A high risk can be expected if the risk quotient exceeds a value 1000. Using this approach, the authors concluded that six of eight evaluated substances used in frac fluids lead to a high risk to human health. OECD (2018) and NRC (2009) describe a similar approach with the metrics hazard quotient (for an individual compound) and hazard index when reviewing the assessment of combined exposures (Fig. 2). It should, however, be kept in mind that the approach by Bergmann et al. (2014) uses the principles of drinking water assessment and, as such, may be critically discussed whether it represents an adequate basis. For example, the threshold values for groundwater were often justified by drinking water limit values or comparable derived toxicological guidance values. Toxicological based regulations for drinking water are based on the principle that $2 \mathrm{~L}$ of water per day can be consumed throughout life without an increased risk to human health. Although high standards should also be maintained concerning frac fluids, the intended use differs widely from that of drinking water and may, therefore, require different procedures for risk assessment.

A multi-criteria decision analysis (MCDA) framework to estimate potential risks for drinking water resources by frac chemicals was presented by Yost et al. (2017). The
MCDA is based on their toxic hazard [chronic Reference Doses (RfDs) and Oral Slope Factors for non-cancer and cancer endpoints], the frequency of use, physio-chemical properties, and their mobility in water. It allows a nationwide or state-specific analysis ranking of frac fluid components. The nationwide analysis (U.S.) of the non-cancer MCDA (37 chemicals in total) indicates the highest Total Hazard Potential Scores for propargyl alcohol, 2-butoxyethanol, $\mathrm{N}, \mathrm{N}$ dimethylformamide, acrylamide, and naphthalene (ranked from high to low). For 2-butoxyethanol, $N, N$-dimethylformamide, and naphthalene, the Occurrence Score and the Physical Properties Score shape the ranking. The cancer MCDA, based on the nationwide analysis of ten chemicals in total, shows acrylamide, bis(2-chloroethyl) ether, quinoline, 1,4-dioxane, and benzyl chloride with the highest Total Hazard Potential Scores. For the first three substances, the tox score determines the overall score.

\section{Produced water}

'Produced water' (or 'production water') has been defined as any type of water that flows to the surface from oil and gas wells (U.S. EPA 2016a). It represents a mixture of flow-back (i.e., injected fluid returning to the surface) and reservoir water, i.e., the water present in natural oil and gas deposits. Early after hydraulic stimulation, e.g., within 1 or 2 days, the produced water contains a relatively high fraction of flow-back with frac fluids. Later, the fraction of reservoir water in the produced water increases. Produced water contains a complex mixture of potentially harmful inorganic and organic chemicals from naturally occurring geogenic compounds, constituents of the frac fluid, and transformation products from biotic and abiotic processes [Hoelzer et al. 2016; Sun et al. 2019 (review)]. Substantial constituents in produced water are the following chemical groups:
Fig. 2 The Hazard Index approach to assess combined exposures to multiple chemicals (OECD 2018; NRC 2009)
The Hazard Quotient (HQ) is equal to divide exposure by the safe dose / reference value. In the context of human health risk assessment, the DNEL, Acceptable Daily Intake (ADI), Thresholds of Toxicological Concern (TTC), RfD or Benchmark Dose Lower Confidence Limit (BMDL) are commonly used as safe dose.

$H Q=$ Exposure $/$ Safe Dose

The Hazard Index (HI) is equal to the sum of each chemical compound's Hazard Quotient:

$$
\mathrm{n}
$$

Hazard Index $=\sum$ Hazard Quotients, $n=$ number of chemical substances $\mathrm{n}=1$

Uncertainty is already incorporated into the $\mathrm{HI}$ and, therefore assessment factors do not need to be applied.

Interpretation: $\mathrm{HI} \leq 1$ : combined risk acceptable; $\mathrm{HI}>1$ : potential concern. 
- inorganic salts including those from chloride, bromide, sulfate, sodium, magnesium and calcium;

- metals including barium, manganese, iron, and strontium;

- radioactive materials including radium-226 and radium-228;

- oil, grease and dissolved organics, including BTEX;

- hydraulic fracturing chemicals, including tracers and their transformation products;

- produced water treatment chemicals.

Interacting factors that can influence the chemical composition of produced water include the composition of injected hydraulic fracturing fluids; the targeted geological formation and associated hydrocarbon products; the stratigraphic environment; subsurface processes and the residence time. Therefore, very different types of contamination have been observed in produced waters. Already in flow-back and produced water, more than a thousand geogenic organic compounds have been identified using GC-FID, GC-MS, and GC $\times$ GC-TOF-MS techniques but only in a qualitatively manner (Luek and Gonsior 2017). Tables 5 and 6 summarize organics, inorganics and further parameters analyzed in produced water that have been reported quantitatively above the limit of detection. The use of U.S. EPA's drinking water MCLs (Maximum Contaminant Levels) to assess the toxicological risk of chemicals in produced water, as it has been performed by some authors (Akob et al. 2015; Ziemkiewicz and He 2015; Sun et al. 2019), appears inadequate because produced water on its own is not a subject of protection.

\section{Environmental pollution and toxicological risks}

Incidents in the surface installations of HF plants may lead to contamination of near-surface groundwater and of surface waters with frac chemicals and production water. Leaks of the drilling holes will cause contamination of the surrounding rock and groundwater. Surface waters can be contaminated by the release of insufficiently treated production water and by leakage from aboveground reservoirs for storage of production water. Recently, four mechanisms have been reported to be particularly relevant for the quality of water resources (Vengosh et al. 2014): (a) contamination of near-surface groundwater by leaking gas wells, diffusive emissions (stray gas), frac fluids and flow-back water; (b) contamination of surface water from inadequately treated production water; (c) accumulation of toxic and radioactive compounds in sediments of rivers and lakes exposed to production water or frac fluids and (d) overexploitation of water resources.

Table 5 Concentrations of organic parameters in produced water from unconventional reservoirs (including shale, tight formation, and coalbed methane)

\begin{tabular}{|c|c|c|c|c|c|c|c|}
\hline \multirow[t]{2}{*}{ Parameters } & \multicolumn{2}{|l|}{ Shale formation } & \multirow{2}{*}{$\begin{array}{l}\text { Tight forma- } \\
\text { tion } \\
\text { Cotton Valley } \\
\text { Group }\end{array}$} & \multicolumn{4}{|c|}{ Coalbed methane } \\
\hline & Barnett & Marcellus & & Powder river & Raton & San Juan & Black Warrior \\
\hline $\mathrm{TOC}(\mathrm{mg} / \mathrm{L})$ & $9.75(6.2-36.2)$ & $160(1.2-1530) 89.2(1.2-5680)$ & ) $198(184-212)$ & $\begin{array}{l}3.52(2.07- \\
6.57)\end{array}$ & $\begin{array}{l}1.74(0.25- \\
13.00)\end{array}$ & $\begin{array}{l}2.91(0.95- \\
9.36)\end{array}$ & $\begin{array}{l}6.03(0.00- \\
103.00)\end{array}$ \\
\hline DOC (mg/L) & $11.2(5.5-65.3)$ & $117(3.3-5960)$ & & $\begin{array}{l}3.18(1.09- \\
8.04)\end{array}$ & $\begin{array}{l}1.26(0.30- \\
8.54)\end{array}$ & $\begin{array}{l}3.21(0.89- \\
11.41)\end{array}$ & $\begin{array}{l}3.37(0.53- \\
61.41)\end{array}$ \\
\hline BOD (mg/L) & $\begin{array}{l}582(101- \\
2120)\end{array}$ & $\begin{array}{l}141(2.8- \\
12,400)\end{array}$ & & & & & \\
\hline $\begin{array}{r}\text { Benzene } \\
(\mu \mathrm{g} / \mathrm{L})\end{array}$ & $680(49-5300)$ & $220(5.8-2000)$ & & & $\begin{array}{l}4.7(\mathrm{BDL}- \\
220.0)\end{array}$ & $\begin{array}{l}149.7 \text { (BDL- } \\
500.0)\end{array}$ & \\
\hline $\begin{array}{r}\text { Toluene } \\
(\mu \mathrm{g} / \mathrm{L})\end{array}$ & $760(79-8100)$ & $540(5.1-6200)$ & & & $\begin{array}{l}4.7 \text { (BDL- } \\
78.0)\end{array}$ & 1.7 (BDL-6.2) & \\
\hline $\begin{array}{l}\text { Ethylbenzene } \\
(\mu \mathrm{g} / \mathrm{L})\end{array}$ & $29(2.2-670)$ & $42(7.6-650)$ & & & $\begin{array}{l}0.8(\mathrm{BDL}- \\
18.0)\end{array}$ & $\begin{array}{l}10.5 \text { (BDL- } \\
24.0)\end{array}$ & \\
\hline $\begin{array}{r}\text { Xylenes } \\
(\mu \mathrm{g} / \mathrm{L})\end{array}$ & $360(43-1400)$ & $300(15-6500)$ & & & $\begin{array}{l}9.9(\mathrm{BDL}- \\
190.0)\end{array}$ & $\begin{array}{l}\text { 121.2 (BDL- } \\
327.0)\end{array}$ & \\
\hline
\end{tabular}

The data are given as average (min.-max.) or median (min.-max.) (from U.S. EPA 2016a, Appendix E; modified)

The data sources corresponding to U.S. EPA (2016a) (Appendix E, Table E-9, modified) were Hayes and Severin (2012), Barbot et al. (2013), Hayes (2009), Blondes et al. (2014), Dahm et al. (2011), and DOE (2014) 
Table 6 Levels of inorganic and organic parameters in flow-back and produced water from unconventional reservoirs

\begin{tabular}{|c|c|c|c|}
\hline Authors (year) & Parameters & Concentration & Matrix, study site \\
\hline \multirow[t]{14}{*}{ Akob et al. (2015) } & \multirow[t]{2}{*}{ Barium } & $15,000 \mathrm{mg} / \mathrm{L}$ (median) & \multirow{14}{*}{$\begin{array}{l}\text { Produced water } \\
\text { Marcellus shale, Burket shale } \\
\text { (Pennsylvania) }\end{array}$} \\
\hline & & $3780-22,400 \mathrm{mg} / \mathrm{L}$ (range) & \\
\hline & Chloride & $109,000 \mathrm{mg} / \mathrm{L}-184,000 \mathrm{mg} / \mathrm{L}$ & \\
\hline & Sodium & $44,800 \mathrm{mg} / \mathrm{L}-63,100 \mathrm{mg} / \mathrm{L}$ & \\
\hline & Calcium & $16,300-39,200 \mathrm{mg} / \mathrm{L}$ & \\
\hline & Strontium & $3390-10,300 \mathrm{mg} / \mathrm{L}$ & \\
\hline & Bromide & $760-1470 \mathrm{mg} / \mathrm{L}$ & \\
\hline & Non-volatile dissolved & $6.7-49.3 \mathrm{mg} / \mathrm{L}$ & \\
\hline & Organic carbon (NVDOC) & & \\
\hline & Low molecular-weight & $0.7-5.6 \mu \mathrm{g} / \mathrm{L}$ & \\
\hline & Organic acid anion (LMWOA) & & \\
\hline & Benzene & $<1.0-1,8 \mu \mathrm{g} / \mathrm{L}$ & \\
\hline & Toluene & $1.0-1.3 \mu \mathrm{g} / \mathrm{L}$ & \\
\hline & Tetrachloroethylene & $<1.0-11.7 \mu \mathrm{g} / \mathrm{L}$ & \\
\hline \multirow[t]{35}{*}{ Lester et al. (2015) } & Aluminum & $0.064 \mathrm{mg} / \mathrm{L}$ & \multirow{35}{*}{$\begin{array}{l}\text { Flow-back; Denver- } \\
\text { Julesburg (Colorado) }\end{array}$} \\
\hline & Arsenic & $0.067 \mathrm{mg} / \mathrm{L}$ & \\
\hline & Boron & $3.105 \mathrm{mg} / \mathrm{L}$ & \\
\hline & Barium & $8.542 \mathrm{mg} / \mathrm{L}$ & \\
\hline & Calcium & $524.1 \mathrm{mg} / \mathrm{L}$ & \\
\hline & Chromium & $0.058 \mathrm{mg} / \mathrm{L}$ & \\
\hline & Cesium & $0.073 \mathrm{mg} / \mathrm{L}$ & \\
\hline & Copper & $0.288 \mathrm{mg} / \mathrm{L}$ & \\
\hline & Iron & $81.42 \mathrm{mg} / \mathrm{L}$ & \\
\hline & Potassium & $101.3 \mathrm{mg} / \mathrm{L}$ & \\
\hline & Lithium & $3.519 \mathrm{mg} / \mathrm{L}$ & \\
\hline & Magnesium & $106.4 \mathrm{mg} / \mathrm{L}$ & \\
\hline & Manganese & $1.471 \mathrm{mg} / \mathrm{L}$ & \\
\hline & Sodium & $6943.9 \mathrm{mg} / \mathrm{L}$ & \\
\hline & Nickel & $0.042 \mathrm{mg} / \mathrm{L}$ & \\
\hline & Rubidium & $0.230 \mathrm{mg} / \mathrm{L}$ & \\
\hline & Silicon & $19.65 \mathrm{mg} / \mathrm{L}$ & \\
\hline & Strontium & $60.25 \mathrm{mg} / \mathrm{L}$ & \\
\hline & Titanium & $0.028 \mathrm{mg} / \mathrm{L}$ & \\
\hline & Vanadium & $0.120 \mathrm{mg} / \mathrm{L}$ & \\
\hline & Zinc & $0.051 \mathrm{mg} / \mathrm{L}$ & \\
\hline & Acetone & $16,000 \mu \mathrm{g} / \mathrm{L}$ & \\
\hline & 2-Butanone & $240 \mu \mathrm{g} / \mathrm{L}$ & \\
\hline & Xylenes & $30 \mu \mathrm{g} / \mathrm{L}$ & \\
\hline & 1,4-Dioxane & $60 \mu \mathrm{g} / \mathrm{L}$ & \\
\hline & 2-Methylphenol & $150 \mu \mathrm{g} / \mathrm{L}$ & \\
\hline & 3- and 4-Methylphenol & $170 \mu \mathrm{g} / \mathrm{L}$ & \\
\hline & 2-Methylnaphthalene & $4 \mu \mathrm{g} / \mathrm{L}$ & \\
\hline & Dimethyl phthalate & $15 \mu \mathrm{g} / \mathrm{L}$ & \\
\hline & Phenanthrene & $3 \mu \mathrm{g} / \mathrm{L}$ & \\
\hline & Pyrene & $0.9 \mu \mathrm{g} / \mathrm{L}$ & \\
\hline & Butyl benzyl phthalate & $4.2 \mu \mathrm{g} / \mathrm{L}$ & \\
\hline & Bis(2-ethylhexyl) phthalate & $29 \mu \mathrm{g} / \mathrm{L}$ & \\
\hline & Phenol & $830 \mu \mathrm{g} / \mathrm{L}$ & \\
\hline & 2,4-Dimethylphenol & $790 \mu \mathrm{g} / \mathrm{L}$ & \\
\hline
\end{tabular}


Table 6 (continued)

\begin{tabular}{|c|c|c|c|}
\hline Authors (year) & Parameters & Concentration & Matrix, study site \\
\hline \multirow[t]{38}{*}{ Ziemkiewicz and He (2015) } & Barium & $\begin{array}{l}10.2 \mathrm{mg} / \mathrm{L} ; 2580 \mathrm{mg} / \mathrm{L} ; 514.68 \mathrm{mg} / \mathrm{L} \text { (minimum, } \\
\text { maximum, mean) }\end{array}$ & Flow-back, \\
\hline & Strontium & $117 \mathrm{mg} / \mathrm{L} ; 4660 \mathrm{mg} / \mathrm{L} ; 1365 \mathrm{mg} / \mathrm{L}$ & Marcellus Shale \\
\hline & Natrium & $2440 \mathrm{mg} / \mathrm{L} ; 119,000 \mathrm{mg} / \mathrm{L} ; 26,202 \mathrm{mg} / \mathrm{L}$ & (West Virginia) \\
\hline & Magnesium & $107 \mathrm{mg} / \mathrm{L} ; 2260 \mathrm{mg} / \mathrm{L} ; 835 \mathrm{mg} / \mathrm{L}$ & \\
\hline & Calcium & $1010 \mathrm{mg} / \mathrm{L} ; 19,900 \mathrm{mg} / \mathrm{L} ; 7269 \mathrm{mg} / \mathrm{L}$ & \\
\hline & Potassium & $44.2 \mathrm{mg} / \mathrm{L} ; 488 \mathrm{mg} / \mathrm{L} ; 260.66 \mathrm{mg} / \mathrm{L}$ & \\
\hline & Iron & $14.7 \mathrm{mg} / \mathrm{L} ; 149 \mathrm{mg} / \mathrm{L} ; 67.08 \mathrm{mg} / \mathrm{L}$ & \\
\hline & Manganese & $1.38 \mathrm{mg} / \mathrm{L} ; 10.2 \mathrm{mg} / \mathrm{L} ; 5.5 \mathrm{mg} / \mathrm{L}$ & \\
\hline & Arsenic & $\mathrm{Nd}$ & \\
\hline & Chromium & $\mathrm{Nd} ; 0.14 \mathrm{mg} / \mathrm{L} ; 0.085 .5 \mathrm{mg} / \mathrm{L}$ & \\
\hline & Mercury & $\mathrm{Nd}$ & \\
\hline & Lead & $\mathrm{Nd} ; 0.1 \mathrm{mg} / \mathrm{L} ; 0.1 \mathrm{mg} / \mathrm{L}$ & \\
\hline & Selenium & $\mathrm{Nd} ; 0.34 \mathrm{mg} / \mathrm{L} ; 0.26 \mathrm{mg} / \mathrm{L}$ & \\
\hline & Silver & $\mathrm{Nd}$ & \\
\hline & Aluminium & $\mathrm{Nd} ; 13.3 \mathrm{mg} / \mathrm{L} ; 4.61 \mathrm{mg} / \mathrm{L}$ & \\
\hline & Zinc & $\mathrm{Nd} ; 0.35 \mathrm{mg} / \mathrm{L} ; 0.14 \mathrm{mg} / \mathrm{L}$ & \\
\hline & Nitrate & $\mathrm{Nd} ; 0.3 \mathrm{mg} / \mathrm{L} ; 0.02 \mathrm{mg} / \mathrm{L}$ & \\
\hline & Nitrite & $\mathrm{Nd} ; 0.8 \mathrm{mg} / \mathrm{L} ; 0.06 \mathrm{mg} / \mathrm{L}$ & \\
\hline & Sulfate & Nd; 108 mg/L; 55.93 mg/L & \\
\hline & Chloride & $4700 \mathrm{mg} / \mathrm{L} ; 79,000 \mathrm{mg} / \mathrm{L} ; 42,683 \mathrm{mg} / \mathrm{L}$ & \\
\hline & Phosphate & $\mathrm{Nd} ; 90 \mathrm{mg} / \mathrm{L} ; 9.49 \mathrm{mg} / \mathrm{L}$ & \\
\hline & Bromide & $52.5 \mathrm{mg} / \mathrm{L} ; 970 \mathrm{mg} / \mathrm{L} ; 465.96 \mathrm{mg} / \mathrm{L}$ & \\
\hline & Benzene & $\mathrm{Nd} ; 372 \mu \mathrm{g} / \mathrm{L} ; 194.47 \mu \mathrm{g} / \mathrm{L}$ & \\
\hline & Ethylbenzene & $\mathrm{Nd} ; 235 \mu \mathrm{g} / \mathrm{L} ; 85.34 \mu \mathrm{g} / \mathrm{L}$ & \\
\hline & Styrene & $\mathrm{Nd} ; 141 \mu \mathrm{g} / \mathrm{L} ; 141 \mu \mathrm{g} / \mathrm{L}$ & \\
\hline & Toluene & $\mathrm{Nd} ; 2450 \mu \mathrm{g} / \mathrm{L} ; 621.71 \mu \mathrm{g} / \mathrm{L}$ & \\
\hline & Xylene $(m, p)$ & $\mathrm{Nd} ; 3380 \mu \mathrm{g} / \mathrm{L} ; 825.75 \mu \mathrm{g} / \mathrm{L}$ & \\
\hline & Xylene $(o)$ & $\mathrm{Nd} ; 673 \mu \mathrm{g} / \mathrm{L} ; 205.5 \mu \mathrm{g} / \mathrm{L}$ & \\
\hline & MBAS & $\mathrm{Nd} ; 0.61 \mathrm{mg} / \mathrm{L} ; 0.42 \mathrm{mg} / \mathrm{L}$ & \\
\hline & Gross Alpha & 1.84 pCi; 20,920 pCi; 5866 pCi & \\
\hline & Gross Beta & $9.6 \mathrm{pCi} ; 4664 \mathrm{pCi} ; 1172 \mathrm{pCi}$ & \\
\hline & Radium-226 & 15.4 pCi;1194 pCi; 358 pCi & \\
\hline & Radium-228 & $4.99 \mathrm{pCi} ; 216 \mathrm{pCi} ; 94.6 \mathrm{pCi}$ & \\
\hline & Thorium-228 & $0.3 \mathrm{pCi} ; 2.35 ; 1.29 \mathrm{pCi}$ & \\
\hline & Thorium-230 & 0 pCi; 9.37 pCi; 2.13 pCi & \\
\hline & Thorium-232 & $0 \mathrm{pCi} ; 0.38 \mathrm{pCi} ; 0.07 \mathrm{pCi}$ & \\
\hline & Uranium-238 & $\mathrm{n} / \mathrm{a} ; \mathrm{n} / \mathrm{a} ; 0.34 \mathrm{pCi}$ & \\
\hline & Potassium-40 & $\mathrm{Nd} 221 \mathrm{pCi} ; 62.44 \mathrm{pCi}$ & \\
\hline \multirow[t]{6}{*}{ Ziemkiewicz (2013) } & Benzene & $\begin{array}{l}6 \mu \mathrm{g} / \mathrm{L} ; 19.7 \mu \mathrm{g} / \mathrm{L} ; 21 \mu \mathrm{g} / \mathrm{L} \text { (flow-back cycle at } \\
\quad \text { days } 7,14 \text { and 35) }\end{array}$ & Flow-back, dry well \\
\hline & Toluene & $3.8 \mu \mathrm{g} / \mathrm{L} ; 12 \mu \mathrm{g} / \mathrm{L} ; 6.8 \mu \mathrm{g} / \mathrm{L}$ & Marcellus Shale \\
\hline & Xylene $(m, p)$ & $0.7 \mu \mathrm{g} / \mathrm{L} ; 6.2 \mu \mathrm{g} / \mathrm{L} ; 3.2 \mu \mathrm{g} / \mathrm{L}$ & (West Virginia) \\
\hline & Benzene & $\begin{array}{l}370 \mu \mathrm{g} / \mathrm{L} ; 18 \mu \mathrm{g} / \mathrm{L} ; 122 \mu \mathrm{g} / \mathrm{L} \text { (flow-back cycle at } \\
\text { days } 7,14 \text { and 35) }\end{array}$ & Flow-back, wet well \\
\hline & Toluene & $2070 \mu \mathrm{g} / \mathrm{L} ; 170 \mu \mathrm{g} / \mathrm{L} ; 525 \mu \mathrm{g} / \mathrm{L}$ & Marcellus Shale \\
\hline & Xylene $(m, p)$ & $2424 \mu \mathrm{g} / \mathrm{L} ; 375 \mu \mathrm{g} / \mathrm{L} ; 525 \mu \mathrm{g} / \mathrm{L}$ & (West Virginia) \\
\hline
\end{tabular}




\section{Contamination of groundwater}

The potential to contaminate groundwater has been considered to be the most relevant risk of HF (Gagnon et al. 2016; Vengosh et al. 2014). Groundwater contaminations may be caused by

- Blowout, i.e., the accidental release of flow-back, production water and hydrocarbons; release of frac fluid by leakage of containers; leakage of production water pipelines.

- Leaking boreholes by deficient casing and cementing; this also refers to leaking drainage wells for disposal of production water.

- Migration of frac fluid components from deeper into more superficial formations.

- Rising of gas (i.e., 'thermogenic methane').

- Rising of deposited production water from deep wells.

Frac chemicals exhibit a relatively low volatility and many of the most frequently used have a high solubility in water and a negative or very low octanol-water partition coefficient (Kow), which supports transfer into groundwater (U.S. EPA 2016a). Solubility of frac fluids may be increased by the presence of solvents, such as methanol or ethanol. Changes in common water quality parameters can be associated with impacts from hydraulic fracturing activities. Measurable changes in methane levels, total dissolved solids (TDS), ratios of geochemical constituents, and isotopic ratios might suggest an impact by HF but could also be from either natural or anthropogenic sources. Specific frac chemicals or specific tracer substances were comparatively little investigated as groundwater contaminants (U.S. EPA 2016a).

A general problem in assessing the influence of HF on the quality of groundwater represents the lack of baseline monitoring before the onset of oil or gas production. However, such baseline monitoring is an important prerequisite for a sound evaluation of possible consequences of HF, particularly in regions with former conventional oil and gas production.
A critical question is to which degree fluid may ascend from deeper formations and reach groundwater (Reagan et al. 2015). Model simulations have shown that frac fluids may ascend by only approximately $50 \mathrm{~m}$ even if large cracks of more than $1000 \mathrm{~m}$ across rock formations occur (Ewen et al. 2012). The largest possible up-flow in vertical fissure systems was estimated to be approximately $215 \mathrm{~m}$ under worst-case assumptions. Other authors also reported that vertical leakage over larger distances is very unlikely (Groat and Grimshaw 2012; BGR 2016). However, the horizontal flux in deep water layers in the geological setting coal seam (Münsterland, Germany) may reach several km, at a rate of $\sim 20$ m per year (Ewen et al. 2012).

\section{Methane in water due to HF activities and conventional oil and gas production}

\section{Groundwater and drinking water}

Methane in ground and drinking water is a common phenomenon already known from conventional oil production (Muehlenbachs 2011). In groundwater, it can not only be of thermogenic origin but can be formed under methanogenic conditions via a biological pathway. The discrimination between thermogenic and biogenic methane is possible by measuring the typical $\delta^{13} \mathrm{C}-\mathrm{CH}_{4}$ and $\delta^{2} \mathrm{H}-\mathrm{CH}_{4}$ isotope fingerprint, the ratio between methane and the sum of ethane and propane, and the percentage of helium in a water sample (McIntosh et al. 2019). In HF, methane may reach the ground and drinking water through damaged cementing and casing of boreholes (Darrah et al. 2014; Dyck and Dunn 1986; Sherwood et al. 2016). Such damage is relatively frequent, with 219 incidents concerning the integrity of a total of 6466 boreholes being reported between 2008 and 2013 (Vidic et al. 2013).

Up until now, methane has been used as an indicator substance for inadequate well integrity and geological disturbance (stray gas). Its use has recently been re-examined more intensively. Methane is a relatively non-toxic, colorless and odorless gas. At high concentrations of 300,000 ppm or $30 \%$ in the breathing air, it acts as an asphyxiant that

Table 7 Action level of the U.S. Department of the Interior (DOI 2001) for methane

\begin{tabular}{lllll}
\hline Action level & Atmospheric (\% volume) & & Concentration in water (mg/L) & Soil gas (\% volume) \\
\cline { 2 - 3 } & Occupiable spaces (homes) & Un-occupiable spaces & & \\
\hline Immediate action & $>1.0 \%$ & $>3.0 \%$ & $>28 \mathrm{mg} / \mathrm{L}$ & $>5.0 \%$ \\
Warning, investigate & $>0.5 \%$ but $\leq 1.0 \%$ & $>1.0 \%$ but $\leq 3.0 \%$ & $>10 \mathrm{mg} / \mathrm{L}$ but $\leq 28 \mathrm{mg} / \mathrm{L}$ & $>3.0 \%$ but $\leq 5.0 \%$ \\
$\begin{array}{l}\text { Monitor to determine } \\
\text { concentration trends }\end{array}$ & $>0.25 \%$ but $\leq 0.5 \%$ & & & $>1.0 \%$ but $\leq 3.0 \%$ \\
No immediate action & $\leq 0.25 \%$ & $\leq 1.0 \%$ & $\leq 10 \mathrm{mg} / \mathrm{L}$ & \\
\hline
\end{tabular}


displaces oxygen in the lungs and causes CNS symptoms and suffocation. Action levels for methane in air and water have been recommended not for toxicological reasons but because of the risk of explosions of air/methane mixtures (Table 7). A drinking water concentration of a similar magnitude has been proposed in Canada ( $3 \mathrm{~L}$ methane $/ \mathrm{m}^{3}$ corresponding to $2 \mathrm{mg}$ methane/L) (Ontario Government 2006). The Canadian threshold value is intended as an 'Aesthetic Objective'. Aesthetic Objectives are established for parameters that may affect the taste, smell or color of the drinking water and are not based on thresholds of adverse health effects. Methane in drinking water causes the release of gas bubbles and violent spurting from water taps.

\section{Methane baseline monitoring in Lower Saxony, Germany}

It is important to monitor background levels in surface water in regions with frac activities. Therefore, a comprehensive survey has been performed in Lower Saxony (Germany), where the occurrence of methane, ethane and propane in near-surface groundwater of $\sim 1000$ groundwater wells was analyzed (Schloemer et al. 2018). Lower Saxony is the largest hydrocarbon province in Germany, where 327 hydraulic stimulations in 148 production wells at depths of $>3000 \mathrm{~m}$ have been performed since 1961 (BGR 2016). The background values for dissolved methane vary from $20 \mathrm{~nL} / \mathrm{L}$ $(14.2 \mathrm{ng} / \mathrm{L})$ to $60 \mathrm{~mL} / \mathrm{L}(42.7 \mathrm{mg} / \mathrm{L})[\mathrm{v} / \mathrm{v}]$, i.e., a range of $\sim 7$ orders of magnitude (Fig. 3). Most analyses are indicative of methanogenic processes. Samples with high $\delta^{13} \mathrm{C}$ contents and methane levels above $10 \mathrm{~mL} / \mathrm{L}(7.1 \mathrm{mg} / \mathrm{L})$ can be mostly accounted for by secondary methane oxidation and biological origin, respectively. Ethane and propane were detected in $27 \%$ and $8 \%$ of all samples, with medians of $50 \mathrm{~nL} / \mathrm{L}$ and $23 \mathrm{~nL} / \mathrm{L}$, respectively. Lower Saxony's methane values indicate that $6 \%(n=60)$ exceed the warning threshold of $10 \mathrm{mg} / \mathrm{L}$ and $1.3 \%$ exceed the threshold for immediate action of $28 \mathrm{mg} / \mathrm{L}$ of U.S. DOI (Table 7). The data of this survey can serve as a possible baseline tool for monitoring in future.

Several studies observed an association between the distance of gas production sites and methane in drinking water and domestic wells. Methane concentrations in drinking water wells in the Marcellus and Utica shale gas formations were 19.2 (average) and 64 (maximum) $\mathrm{mg} / \mathrm{L}$ if a gas well was within a distance of $1 \mathrm{~km}$ (Osborn et al. 2011). These concentrations are so high that they increase the risk of fire and explosions (Table 7). By contrast, drinking water wells in the same region and a similar hydrogeology without gas wells in the neighborhood contained methane concentrations of only $1.1 \mathrm{mg} / \mathrm{L}$ (Osborn et al. 2011). Similar results were obtained in a study of 141 water wells in the Appalachian Plateau (Jackson et al. 2013). Concentrations of methane were approximately sixfold higher in drinking water wells within a distance of $1 \mathrm{~km}$ from gas wells compared to drinking water wells without neighboring gas production. In contrast to these findings, a third study (Siegel et al. 2015) did not observe a relationship between methane concentrations in individual home wells and oil or gas wells in the neighborhood.
Fig. 3 Methane in Lower Saxony's groundwater (geodetic coordinates of sampling points according to WGS84 (1984))

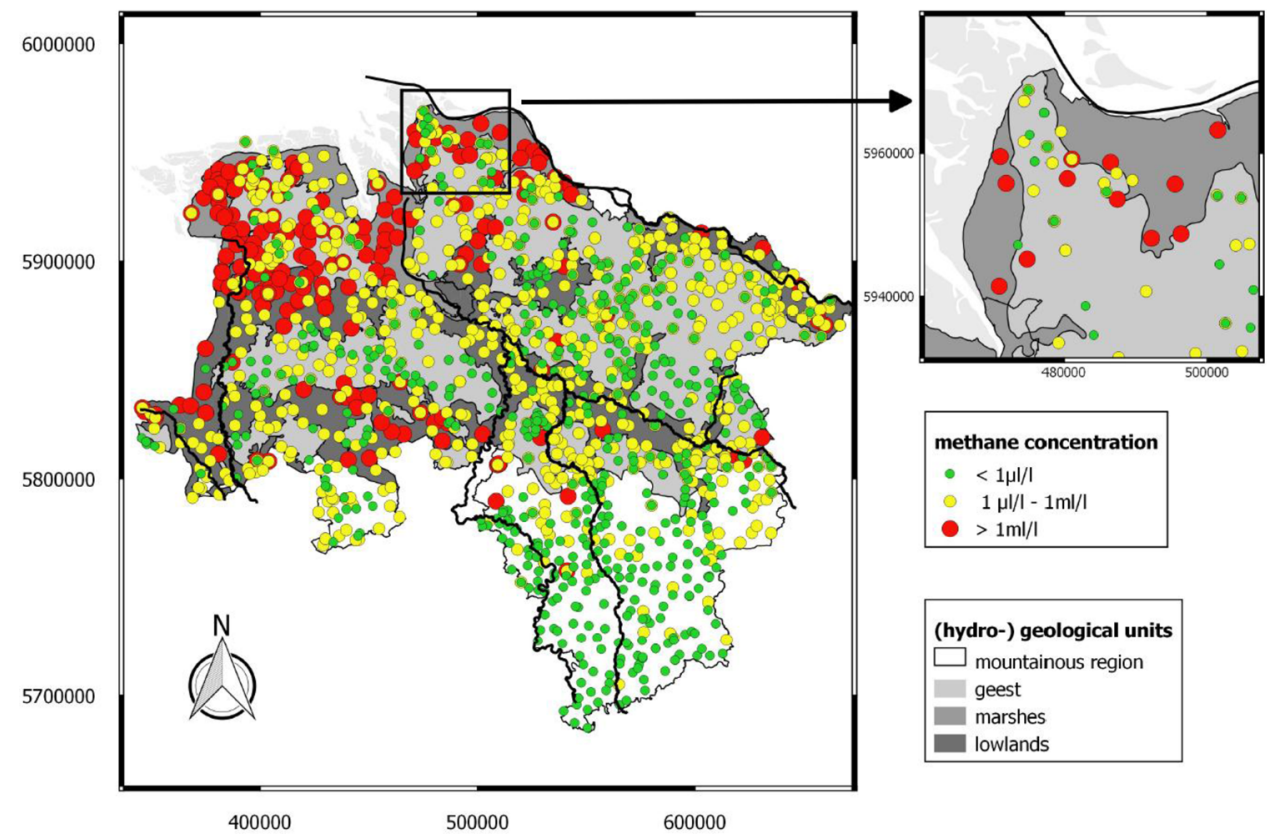




\section{Compromised groundwater quality by vertical mixing}

Mixing groundwater layers of different depths (vertical mixing) due to extensive groundwater production required for $\mathrm{HF}$ can compromise the quality of groundwater. One explanation for this is that high-quality groundwater is mixed with higher water layers that are contaminated by nitrates or pesticides from surface-related activities. Moreover, highquality groundwater close to the surface can be mixed with groundwater of deeper hydrogeological formations, leading to increased concentrations of chemicals such as arsenic, chloride, fluoride, manganese, and uranium. Examples of these effects have been documented by the U.S. EPA (2016a).

\section{Studies of groundwater contamination by frac fluids}

Studies investigating the influence of HF on groundwater quality are challenging due to potential preexisting contaminations. It has been estimated that up to three million abandoned oil and gas wells exist in the USA (Gagnon et al. 2016). This emphasizes the importance of identifying all historical data on groundwater quality in relation to previous industrial activities. DiGiulio and Jackson (2016) performed a comprehensive analysis of publicly available analytical data and reports of U.S. EPA, U.S. Geological Survey (USGS), Wyoming Oil and Gas Conservation Commission (WOGCC), and Wyoming Department of Environmental Quality (WDEQ) published from August 2009 to December 2015. They used these data to evaluate the impact on underground sources of drinking water as a result of acid stimulation and hydraulic fracturing in the Pavillion Field, Wyoming. The field comprises 181 production wells, including plugged and abandoned wells. Acid stimulation and hydraulic fracturing began in June 1960 and October 1964, respectively, and occurred only as deep as 213 and $322 \mathrm{~m}$ below the ground surface, respectively. These depths are comparable to deepest domestic groundwater use in the area. In response to complaints of residents regarding foul taste and odor in water from domestic wells within the Pavillion Field, the EPA conducted domestic well sampling in March 2009 and January 2010. In 2010, the U.S. EPA installed two monitoring wells (MW01 and MW02) with screened intervals at 233-239 $\mathrm{m}$ and 296-302 $\mathrm{m}$ below the ground surface, respectively. MW01 and MW02 were installed to evaluate potential upward solute transport of chemicals associated with well stimulation to maximum depths of groundwater use $(\sim 322 \mathrm{~m})$. In general, the overall vertical groundwater gradient in the Pavillion Field is directed downwards but there is hydrological evidence of localized upwards directed hydraulic gradients, which could contribute to potential upward migration of dissolved compounds from depths of HF stimulation. Analysis of groundwater samples of MW01 and MW02 collected in 2010, 2011, and 2012 resulted in the detection of a multiplicity of frac fluids components and increased iron concentrations that indicates the pollution by HF activities. Methanol, ethanol, and isopropanol quantities of up to $863,28.4$, and $862 \mu \mathrm{g} / \mathrm{L}$, respectively, were measured. Tert-butyl alcohol was detected at $6120 \mu \mathrm{g} / \mathrm{L}$ in one well. Tert-butyl alcohol in groundwater has been associated with degradation of tert-butyl hydroperoxide used for HF but it can also be produced by the degradation of methyl tertbutyl ether (MTBE) associated with diesel fuel. Diethylene glycol and triethylene glycol were detected in both wells at maxima of 226 and $12.7 \mu \mathrm{g} / \mathrm{L}$, respectively, in MW01, and at 1570 and $310 \mu \mathrm{g} / \mathrm{L}$, respectively, in MW02. Tetraethylene glycol was detected only in MW02 at $27.2 \mu \mathrm{g} / \mathrm{L}$. Diesel range organics (DRO) and gasoline range organics (GRO) were detected in MW01 and MW02 with maximum DRO concentrations of 924 and $4200 \mu \mathrm{g} / \mathrm{L}$, respectively, and GRO concentrations of 760 and $5290 \mu \mathrm{g} / \mathrm{L}$, respectively. 1,3,5-, 1,2,4-, and 1,2,3-trimethylbenzene were measured at maximum concentrations of $71.4,148$, and $45.8 \mu \mathrm{g} / \mathrm{L}$, respectively, in MW02, and at an order of magnitude lower concentrations in MW01. Naphthalene, methylnaphthalenes, and alkylbenzenes were also detected in MW02 at concentrations up to $7.9,10.2$, and $21.2 \mu \mathrm{g} / \mathrm{L}$, respectively. Trimethylbenzenes and naphthalenes have been used in frac fluid mixtures. The aromatics benzene, toluene, ethylbenzene, $m-/ p$-xylenes, and $o$-xylene were detected in MW02 at maximum concentrations of $247,677,101,973$, and $253 \mu \mathrm{g} / \mathrm{L}$, respectively, but not in MW01. 2-Butoxyethanol, which was used extensively for well stimulation in the Pavillion Field, was detected in both monitoring wells at maxima of $12.7 \mu \mathrm{g} / \mathrm{L}$. Other substances such as phenol, substituted phenols, ketones, lactate, formate, acetate, propionate, and benzoic acid were also measured quantitatively in the monitoring wells. Detection of organic compounds or degradation products of chemicals that have been used in frac fluids for production well stimulation in MW01 and MW02 provide evidence of an impact to groundwater and indicate upward solute migration to depths of groundwater use under the specific hydrogeological conditions. Additionally, the anomalous concentrations of major ions in domestic wells suggest an influence of well stimulation. Detection of DRO/GRO and further organic compounds in domestic wells $<600 \mathrm{~m}$ from unlined pits used up until the mid-1990s to dispose diesel-fuel-based drilling mud and production fluids suggests an impact on domestic wells. DRO and GRO in samples of these domestic wells ranged from 17.3 to $479 \mu \mathrm{g} / \mathrm{L}$, and 21.6 to $48 \mu \mathrm{g} / \mathrm{L}$, respectively. 
A comprehensive analysis of a possible influence of shale gas production on the quality of groundwater has been performed in the Marcellus Shale, a production site in Pennsylvania (Boyer et al. 2012). A relatively high number of domestic drinking water wells $(n=233)$ in rural areas close to gas production sites were studied. Samples were taken before, as well as 8 months and up to 800 days after drilling HF activities. The authors did not observe any significant changes in drinking water after frac activities, analyzing the conventional organic and inorganic parameters of drinking water quality [e.g., $\mathrm{pH}$, turbidity, TDS, dissolved organic carbon (DOC), total dissolved nitrogen (TDN), chloride, iron, barium, sodium, manganese, sulfate, magnesium, strontium, calcium, arsenic, lead, nitrate, chromium, cadmium, selenium, mercury, silver, bromide, sulfide, methane, BTEX, MBAS-tensides, oil and grease, and radioactivity]. Individual frac fluid organics were not analyzed. It should be taken into account that drinking water quality of the 233 private water wells sampled was partially already impaired before the onset of HF activities, with many values exceeding drinking water standards: $\mathrm{pH}$ (17\% of 233 samples), TDS (3\% of 233 samples), iron ( $20 \%$ of 222 samples), barium ( $1 \%$ of 218 samples), manganese (27\% of 203 samples), arsenic (4\% of 115 samples), turbidity ( $32 \%$ of 102 samples), coliform bacteria (33\% of 125 samples), fecal coliform bacteria (33\% of 122 samples), and lead (7\% of 104 samples). Most notable was the exceedance of the drinking water standards in pre-drilling samples for both bacterial parameters by factors of more than 201, followed by manganese, iron, lead, turbidity by factors of $133,68,22$, and 21 , respectively. The BTEX aromatics were all below the limit of detection (LOD). Pre- and post-drilling methane concentrations were tested in 48 water wells. This compound was already present in about $20 \%$ of pre-drilling samples, partially at peak concentrations as high as $58.30 \mathrm{mg} / \mathrm{L}$ that led to an explicit risk of explosions. Most post-drilling methane levels were generally near or below the LOD $(<0.02 \mathrm{mg} / \mathrm{L})$, even after drilling and frac activities had occurred. Methane increased at one drilled site to $\sim 9 \mathrm{mg} / \mathrm{L}$ but this well also had a moderate level of methane before drilling occurred. The obtained data on methane concentrations from all 48 private water wells were used to compare pre- to post-drilling methane levels. Among these samples, there were no statistically significant increases in methane levels after drilling, and no statistically significant correlations to distance from drilling. Therefore, the authors interpreted these observations as a lack of impact of HF activities (Boyer et al. 2012).

Bromide is typically not detected in undisturbed groundwater and occurs in drinking water at levels well below those of health concern (WHO 2017). As bromide can be found at relatively high concentrations in formation or produced water/flow-back, it could be used as an indicator of the impact on groundwater from these sources. All pre-drilling bromide concentrations were $<$ LOD $(0.10 \mathrm{mg} / \mathrm{L})$. However, in 1 of 26 water wells, bromide was detected at a concentration of $0.5 \mathrm{mg} / \mathrm{L}$ after well stimulation (Boyer et al. 2012). This water quality change may have been caused by mixing with existing formation water during the drilling or frac procedure. The elevated bromide concentration still falls below WHO's (2009) health-based drinking water value of $6 \mathrm{mg}$ bromide/L. None of the control water wells or wells near gas wells that had only been drilled and not fracked had measurable bromide concentrations during the post-drilling testing. The fact that the sum parameter DOC was unchanged despite the elevated bromide suggests that this parameter would not be suitable for qualitatively detecting organic frac chemicals.

A further study of drinking water quality was performed in the Barnett Shale, a production site in Texas (Fontenot et al. 2013). The authors analyzed samples from 91 private drinking water wells located at a distance of either more or less than three $\mathrm{km}$ from active natural gas wells, and $9 \mathrm{sam}$ ple reference sites outside the Barnett Shale region. Some water samples from active wells within three $\mathrm{km}$ distance exceeded the drinking water maximum contaminant levels (MCL) of the U.S. EPA for arsenic (29 of 90 samples), selenium (2 of 10 samples), strontium (17 of 90 samples), and TDS (50 of 91 samples). The MCLs were exceeded by maximum factors of 16 (arsenic) and 2 (selenium). Samples from reference sites, as well as wells more than three km away from active natural gas wells, contained lower concentrations of arsenic, selenium, strontium and barium. However, the MCLs for TDS had already been exceeded in the historical data (1989-1999) $(61 \% \geq \mathrm{MCL})$ and in the non-active and reference area $(78 \% \geq \mathrm{MCL})$. Methanol was detectable in $29 \%$ of all samples, of which 24 samples were from active extraction area wells and ranged from 1.3 to $329 \mathrm{mg} / \mathrm{L}$. Methanol in samples from non-active and reference area wells ranged from 1.2 to $62.9 \mathrm{mg} / \mathrm{L}(n=5)$. Ethanol was detected in eight samples from active extraction area wells in concentrations ranging from 1 to $10.6 \mathrm{mg} / \mathrm{L}$, and in four samples from non-active and reference area wells ranging from 2.3 to $11.3 \mathrm{mg} / \mathrm{L}$. Both alcohols were often included as anticorrosive agents in frac fluids (Table 1) but can also occur naturally in groundwater and be formed as a by-product of microbial metabolism. The spatial pattern of the data suggests that elevated levels of some parameters could be attributed to different factors. These include the mobilization of geogenic components, hydrogeological changes due to a lowered groundwater line, or damaged casing/cementing. According to the authors, the evidence for a direct association of elevated concentrations in the groundwater to Barnett shale $\mathrm{HF}$ activities remains uncertain. 
A further study analyzed water samples from 65 wells in the neighborhood of shale gas production sites in the southwest of Pennsylvania (Alawattegama et al. 2015). Here, consumer reports concerning deterioration in drinking water quality (color, taste or smell) coincided with the beginning of shale gas activities from 2009 onwards. Since 2009, 65 horizontal wells were drilled within a $4 \mathrm{~km}$ radius of the community, each well was stimulated on average with $13,249 \mathrm{~m}^{3}$ (3.5 million gal) of fluids and 1,451,496 kg (3.2 million lbs) of proppant. Initially, 57 water samples from 33 wells were collected and analyzed. Anion analysis of these water samples for chloride, bromide, fluoride, sulfate, phosphate, and nitrate indicated that none exceeded the drinking water MCLs and nitrite levels were below the LOD $(0.0054 \mathrm{mg} / \mathrm{L})$. The analysis of 31 analytes by means of ICP-MS (major ions, trace metals, inorganic chemicals, and radionuclides e.g., uranium) showed that the respective MCLs were exceeded by aluminium by a factor of 2.6 (one sample), iron by at most a factor of 1.4 (two samples), and manganese by, at most, a factor of 52.5 (25 samples). Cadmium and uranium concentrations were $<0.021 \mu \mathrm{g} / \mathrm{L}$ and $<0.05 \mu \mathrm{g} / \mathrm{L}$, respectively. Methane was detected in 14 of the 18 wells tested, ranging from 0.33 to $1557 \mu \mathrm{g} / \mathrm{L}$. These values are below the proposed methane action levels (Table 7). Ratios of methane to higher chain hydrocarbon of less than $\sim 100$ and $813 \mathrm{C}-\mathrm{CH}_{4}$ positive in more than $50 \%$ have been interpreted as indicative of thermogenic gas. Methane to ethane ratios in 4/5 of the 14 investigated samples were $<100$. As isotopic analyses were not conducted, the origin of the measured methane remains unknown.

A very probable case of contamination of drinking water by frac fluids in the context of a near-surface to mid-depth long-reaching lateral geological perturbation has recently been published (Llewellyn et al. 2015). This study was performed because several households reported foaming of drinking water from domestic wells. Using high-resolution two-dimensional gas chromatography/mass spectrometry (GC/GC-TOF-MS), 2-butoxyethanol was identified in drinking water, which also was present in the flow-back (Llewellyn et al. 2015). Although 2-butoxyethanol was detectable only at very low concentrations of $<1 \mathrm{ng} / \mathrm{L}$, it is very likely that it originated from frac activities. Notably, the U.S. EPA suggested this compound as an indicator of contamination due to frac chemicals (Tables 1, 4). Moreover, ethylene- and propylene glycol, as well as MBAS-tensides (methylene blue active substances), were identified in the $\mu \mathrm{g} / \mathrm{L}$-concentration range, which is close to the detection limit. The concentration of methane partially exceeded the action thresholds given in Table 7.

The U.S. EPA (2016a) has examined the impact of HF on drinking water resources at various individual sites. Several cases of contamination of drinking water aquifers were observed. In Killdeer, North Dakota, water quality samples were collected from three domestic wells, nine monitoring wells, two supply wells, one municipal well, and one state well from $07 / 2011$ to $10 / 2012$. Two study wells installed less than $20 \mathrm{~m}$ from the production well (NDGW08 and NDGW07) had significant differences in water quality compared to the remaining study wells. They showed differences in ion concentrations (e.g., chloride, calcium, magnesium, sodium, strontium) and tert-butyl alcohol. The lack of MTBE and other signature compounds associated with gasoline or fuels strongly suggests that a well blowout was the only source consistent with findings of high brine and tert-butyl alcohol concentrations in the two wells. The incident in Bainbridge Township, Ohio, is an example of insufficient and improperly cementing of the well. During the HF operation in 11/2007, 3200 L of frac fluid flowed up the annulus and out of the well. The increasing pressure in the wellbore contributed to thr release of stray gas and resulted in the contamination of 26 private drinking water wells with methane. Another study in Mamm Creek, Colorado, demonstrated similar results. The Mamm Creek field is in an area where lost cement and shallow, gas-containing formations are common. As a consequence, methane has been found in several drinking water wells, along with seeps into local creeks and ponds. The proposed route of contamination was contaminants flowing up the well annulus and then along a fault.

The U.S. EPA reported that the most probable reason for drinking water contamination is the damage of casing and cementing of drilling holes that leads to spills (U.S. EPA 2016a). A median spill rate of 2.6 per 100 wells was reported (ranging from 0.4 to 12.2 spills per 100 wells), based on reported incidents in the three mentioned states. Not all spills reach and impact a drinking water resource. If approximately $5-20 \%$ of spills reach surface water or groundwater, a spill would be expected to occur and reach a drinking water resource at $0.05-2 \%$ of active or hydraulically fractured wells (U.S. EPA 2016a).

Leakage of chemicals of the frac fluid and of production water is considered as the most relevant cause of groundand drinking water contamination (Costa et al. 2017). A first systematic analysis of publicly available data of leakage incidents of HF activities documents 77 cases in Colorado between July 2010 and July 2011 (Gross et al. 2013). In this period, 18,000 active wells were considered and leakages were reported for $\sim 0.5 \%$ of those wells. Concentrations of benzene, toluene, ethylbenzene and xylene (BTEX) in groundwater from contaminated regions exceeded the current national Drinking Water MCLs of the U.S. EPA in 90, 30,12 and $8 \%$ of the samples, respectively (Gross et al. 2013). Concentrations of benzene and toluene exceeded MCLs by factors of 220 and 2.2, respectively. Restorative measures led to a rapid decline of BTEX concentrations in the groundwater. 
The question of whether HF leads to widespread and systematic groundwater pollution is a matter of controversy. In its draft on the "Assessment of the Potential Impacts of Hydraulic Fracturing for Oil and Gas on Drinking Water Resources" from 2015, the U.S. EPA concluded that there was no such impact, but in response to criticism of the EPA's Science Advisory Board (U.S. EPA 2017), it made the conclusion much more open in the final report (U.S. EPA 2016a). Following this question, Hill and Ma (2017) examined whether shale gas development systematically impacts public drinking water quality in Pennsylvania. The authors used chemical analysis data limited to chemicals that are likely related to HF from 54,809 water samples spanning 5 years, beginning in 2011, for 424 groundwater-based community water systems, whose intakes lie within $10 \mathrm{~km}$ of at least one well pad. Water systems serve an average population of 787 (SD 1876) and have an average of 2.9 intake locations (SD 2.4). A difference-in-difference strategy was employed that compares, for a given community water system, water quality after an increase in the number of drilled well pads to background levels of water quality in the geographic area as measured by the impact of more distant well pads. Drilling an additional well pad within $1 \mathrm{~km}$ of groundwater intake locations increases shale gasrelated contaminants by an average of $1.5-2.7 \%$. The authors concluded from their results that the health impacts of HF through water contamination remain an open question.

A pilot study in three rural communities of Lower Saxony (Germany) indicated that there was no effect of frac operations in a tight gas reservoir on the groundwater quality of the near-surface aquifer. Since 1980, 53 frac operations have been performed in this deposit. Water from domestic wells in the neighborhood of the natural gas production was sampled during 2014 and 2015. A comprehensive analysis according to the German Drinking Water Ordinance showed no critical contaminations with BTEX, polycyclic aromatic hydrocarbons or metals, or substances from a non-targetGC-MS screening (Wollin et al. 2015a, b). Specific frac chemicals could not be detected. In addition, well water in the neighborhood of an injection well for disposal of oil- and gas-related wastewater did not show critical pollution by the disposed produced water (Wollin 2016a).

A recent study evaluated the water quality of private water wells in a county in Texas (Granados et al. 2019). Furthermore, the survey included questions regarding water quality, as well as an assessment of the individual health status of 75 residents living within the Eagle Ford Shale region. Well water samples $(n=19)$ from volunteers were tested for a variety of water quality parameters (inorganic cations and anions, sum parameters, frac fluid-related alcohols, aromatic compounds, aldehydes, amines, and chlorinated compounds). Of the private wells sampled, seven exceeded the U.S. EPA's drinking water MCLs for chloride, nitrate, sulfate, and strontium. In one of the 19 wells, concentrations of the frac fluid-related chemicals, methanol, ethanol, and isopropyl alcohol, were 150,20 , and $90 \mathrm{mg} / \mathrm{L}$, respectively. For methanol, for which there is no MCL available, a drinking water value of $14 \mathrm{mg} / \mathrm{L}$ can be derived on the basis of the reference dose (RfD) for methanol by the oral route of $2.0 \mathrm{mg} / \mathrm{kg}$ body weight per day (U.S. EPA IRIS 2013) and using a default allocation factor of the RfD of $20 \%$. The analyzed methanol concentration of $150 \mathrm{mg} / \mathrm{L}$ exceeds this value by a factor of 11 . From the 75 participants of the study, the main three sources of drinking water were reported to be the home city water supply $(n=17)$, private wells $(n=14)$, and grocery store/purchased water $(n=44)$. Of note, confidence in safety to drink home tap water was highest in the group of participants using private wells (13 of 14 wells). The majority of the participants did not have confidence in the quality of their drinking water, with many reporting changes in smell and appearance.

\section{Contamination of groundwater by activities above the surface}

\section{Organic compounds}

Numerous specific organic chemicals are used during HF activities. A comprehensive study was performed in the Marcellus Shale formation to clarify whether these compounds can reach shallow groundwater aquifers and affect local water quality after injection into deep shale horizons (Drollette et al. 2015). The authors detected hydrocarbons from diesel in 23 of 41 analyzed groundwater samples at concentrations ranging up to $157.6 \mu \mathrm{g} / \mathrm{L}$. BTEX concentrations were below the U.S. EPA MCLs for drinking water. The presence of bis (2-ethylhexyl) phthalate was demonstrated, a disclosed HF additive, which was not detectable in geogenic water samples and field blanks (Drollette et al. 2015). Inorganic chemical fingerprinting of deep saline groundwater, analysis of characteristic noble gas isotopes, and studies of spatial relationships of shale gas allowed the differentiation between naturally occurring saline groundwater and contaminated water, e.g., by accidental leaks (Drollette et al. 2015). The authors concluded that contamination of groundwater was more likely to be due to the accidental release of chemicals derived from the surface than to subsurface flow of the injected organic compounds. 


\section{Contamination by leakage of production water pipelines}

In Lower Saxony, the center of natural gas production in Germany, leakage of production water pipelines has been repeatedly reported, with the consequence of contaminations of soil and groundwater (LBEG 2019a). After several incidents of leakage of the polyethylene pipelines, in April 2011, the Saxony Authority for Mining, Energy and Geology ordered that the responsible company should prove that the used synthetic pipeline was tight under the expected mechanical, thermic and chemical stresses. As a consequence of this check completed in May 2012, approximately 44 of a total of $740 \mathrm{~km}$ pipeline had to be decommissioned. However, even after May 2012, various cases were reported on the discharge of deposit water or wet oil, leading to contamination of soil and groundwater. Contamination was usually restricted to the direct environment of leakage and normally only a few square meters of soil were affected. The volumes of produced water were generally less than $2 \mathrm{~m}^{3}$. Adverse effects of residents in the neighborhood of leaking pipelines were not reported (LBEG 2019a).

\section{Contamination of surface waters and consequences for drinking water quality}

Ground- and surface water represent important resources for the generation of drinking water. Therefore, it may lead to critical situations if surface water is used for both disposal of flow-back/production water and generation of drinking water. Direct injection or indirect discharge of inadequately cleared production water from oil or gas production into surface water represents a potential risk. Direct injection of production water is still of high relevance in the USA. Although this route of water disposal is generally prohibited according to the "oil and gas extraction effluent guidelines and standards" of the U.S. EPA (40 U.S. Code of Federal Regulations, CFR, 125.3, subpart C), exceptions are allowed in the arid zones of the USA west of the 98th longitude (U.S. EPA 2016a). In the latter case, surface water discharge of produced water has a portion of all disposal practices between two (California) and ten percent (Colorado). For Texas and Utah, five and six percent, respectively, are reported whereas in Arizona, North Dakota and Oklahoma, the portion amounts to zero percent.

Compounds in production water/flow-back depend on the specific geological formations (Shrestha et al. 2017; Luek and Gonsior 2017). Production water often contains inorganic compounds, such as bromide, chloride, iodide, barium, calcium, copper, iron, magnesium, strontium, sulfur, arsenic, selene and 'Naturally Occurring Radioactive Material'
(NORM) (Ferrar et al. 2013; Warner et al. 2013; Weaver et al. 2016). Indicators for the analysis of a possible contamination of surface water by HF wastewater are chloride and 'Total Suspended Solids' (TSS) (Gagnon et al. 2016).

Flow-back/production water also contains numerous organic compounds, particularly benzene and BTEX. Importantly, sewage plant outflow, municipal facilities, as well as specialized plants for industrial wastewater, still contain toxic metals, e.g., barium and strontium, radioactive elements, e.g., radium isotopes, benzene, toluene, and high salt concentrations (TDS up to $254,000 \mathrm{mg} / \mathrm{L}$ ) despite treatment (Ferrar et al. 2013). Bromide in HF wastewater and its environmental relevance have been intensively studied because it is only partially removed by sewage plants (Warner et al. 2013). Therefore, the disposal of cleared water from sewage plants into surface water may lead to increased bromide concentrations. Bromide concentrations in production water of the Marcellus formation of 1283, 787 and $744 \mathrm{mg} / \mathrm{L}$ have been reported, while $643 \pm 201 \mathrm{mg} / \mathrm{L}$ (standard deviation) was measured in the effluent wastewater treatment plants. Other studies also reported relatively high bromide concentrations in the flow-back, ranging between 16 and $1190 \mathrm{mg} / \mathrm{L}$ and <LOD and $613 \mathrm{mg} / \mathrm{L}$ (Hayes 2009; Haluszczak et al. 2013). In unpolluted freshwater, bromide concentrations are much lower, ranging between $<\mathrm{LOD}$ and $0.5 \mathrm{mg} / \mathrm{L}$. In seawater, concentrations are reported to range between 65 and $80 \mathrm{mg} / \mathrm{L}$ (WHO 2009).

Human toxicity of bromide after chronic oral uptake is considered to be low. A drinking water value of $6 \mathrm{mg}$ bromide/L drinking water has been derived by the WHO, based on an Acceptable Daily Intake (ADI) of $0.4 \mathrm{mg} /$ $\mathrm{kg}$ body weight/day for a person of $60 \mathrm{~kg}$, consuming 2 $\mathrm{L}$ drinking water per day and the assumption that $50 \%$ of bromide exposure occurs via drinking water (WHO 2009). However, bromide can be transformed into more toxic compounds during drinking water treatment. Increased bromide concentrations in water can lead to increased levels of Brominated Disinfection By-products (DBP) and thus far unregulated compounds, such as halonitromethane, haloamide and haloacetonitriles (Parker et al. 2014; Weaver et al. 2016). For example, drinking water disinfection with elementary chlorine, chloramine and ozone in the presence of organic compounds in water may lead to the formation of trihalomethane and halogenated acetic acids. For some of these compounds, health-based guidance values have been derived, e.g., $100 \mu \mathrm{g} / \mathrm{L}$ for bromoform and dibromochloromethane and $60 \mu \mathrm{g} / \mathrm{L}$ for bromodichlormethane in drinking water. Drinking water disinfection with ozone may lead to oxidation of bromide to the mutagenic and carcinogenic bromate, for which $10 \mu \mathrm{g} / \mathrm{L}$ has been set as a provisional guideline value (WHO 2017). This guideline value is provisional because of limitations in available analytical and treatment methods. A health-based value of $2 \mu \mathrm{g}$ bromate/L 
can be derived using an upper-bound estimate of cancer potency for bromate of 0.19 per $\mathrm{mg} / \mathrm{kg}$ body weight per day, based on low-dose linear extrapolation. A one-stage Weibull time-to-tumor model was applied to the incidence of mesotheliomas, renal tubule tumors and thyroid follicular tumors in male rats given potassium bromate in drinking water. The concentration of $2 \mu \mathrm{g} / \mathrm{L}$ is associated with the upper-bound excess cancer risk of $10^{-5}$ (WHO 2009). However, WHO (2017) states also "emerging evidence" pointing "to rapid decomposition of bromate in the gastrointestinal tract, blood and liver, which supports a non-linear dose-response relationship at low doses".

Quantitative aspects of the formation of brominated and iodinated trihalomethane (THMs) and haloacetonitriles (HANs) in mixtures of HF wastewater and surface water have been analyzed for the Ohio and Allegheny rivers and the Marcellus formation (Parker et al. 2014). Even chlorination of a mixture with as little as $0.01 \% \mathrm{HF}$ wastewater leads to the formation of THMs and HANs, which was more pronounced in both substance classes at a level of $0.03 \%$ wastewater. Chloramine reduces HAN formation and regulates THM formation. In river water affected by municipal wastewater treatment processes, a HF wastewater percentage of $0.1 \%$ increases the formation of $\mathrm{N}$-nitrosodimethylamine at iodide levels of $54 \mathrm{ppm}$ during the reaction with chloramine. A significant increase in bromate formation was observed at a fraction of $0.01-0.03 \%$ HF wastewater. The authors recommend an alternative modified disinfection strategy that includes the change of chlorine to chloramine, the general prevention of the introduction of HF wastewater in surface waters, or the removal of the salt load in the wastewater.

The direct discharge of HF wastewater has already been prohibited in Pennsylvania (in 2011) since this state was particularly affected by contamination of surface waters due to HF. Nevertheless, increased concentrations of bromide were also observed after this ban. Also, the isotope ratios of ${ }^{87} \mathrm{Sr} /{ }^{86} \mathrm{Sr}$ and ${ }^{228} \mathrm{Ra} /{ }^{226} \mathrm{Ra}$ in receiving waters of Pennsylvania suggested that the HF outflow was further directly discharged into surface waters or that clearance of wastewater was insufficient (States et al. 2013).

Concentrations of toxic and radioactive elements in produced water have been reported to correlate with salinity, which may be explained by the geochemical properties of rock layers and deep water (Vengosh et al. 2014). Accumulation of radioactive elements has been observed in sediments of rivers and lakes, where produced water has been discharged. ${ }^{226} \mathrm{Ra}$ levels in sediments of rivers of $544-8759 \mathrm{~Bq} /$ $\mathrm{kg}$ were detected that were approximately 200 -fold higher compared to sediments upstream of the position of the discharge of production water (Warner et al. 2013). The general background radioactivity ranged between 22 and $44 \mathrm{~Bq} / \mathrm{kg}$.

Meanwhile, U.S. EPA modified its "Oil and Gas Extraction Effluent Guidelines and Standards (40th U.S. Code of
Federal Regulations (CFR) Part 435)”. Under Subpart C, they prohibit the discharge of unconventional natural gas effluents to municipal sewage treatment plants (US EPA 2016b).

\section{Adverse soil alterations}

\section{Local contamination of soil at production sites}

Local contamination can result from the disposal of excavated material from drilling of the natural gas borehole close to the gas well site in oil sludge pits and from improperly performed maintenance and cleaning works on the site. Possible consequences are contaminations of groundwater, point pollution of soil and toxic air emissions. Another pathway of point pollution is the accidental HF wastewater surface spill on soil.

Oetjen et al. (2018) studied the ability of surfactants in HF wastewater to be transported through agricultural soil and to mobilize metals in soil using column experiments. Of the 27 surfactants (including polyethylene glycols, benzalkonium chlorides, and alkyl ethoxylates) known to be present in the wastewater samples or of their transformation products, none were measured in leachate samples. Conversely, copper, lead, and iron were mobilized at environmentally relevant concentrations: dissolved copper and lead concentrations increased from $40 \mu \mathrm{g} \mathrm{Cu} / \mathrm{L}$ and from below the detection limit of $2 \mu \mathrm{g} \mathrm{Pb} / \mathrm{L}$ during simulated rain events up to $300 \mu \mathrm{g} \mathrm{Cu} / \mathrm{L}$ and $12 \mu \mathrm{g} \mathrm{Pb} / \mathrm{L}$ in leachate.

\section{Local soil contamination in Germany: mercury, PAHs and benzene}

Natural gas in Northern Germany may contain mercury in concentrations of up to $4.5 \mathrm{mg} / \mathrm{m}^{3}$. Contamination of soil with mercury would be a major concern since it is neuro-, nephro-, and reprotoxic. In addition to mercury, PAHs and benzene should also be considered as toxicologically relevant contaminants. Therefore, soil and sediment samples in the vicinity of 211 active natural gas production sites in Lower Saxony (Northern Germany) were systematically analyzed between July 2015 and May 2017 (Schneider et al. 2018). The analytical program comprised metals, heavy metals including mercury, organic compounds ( $\mathrm{PAH}, \mathrm{C}_{10}-\mathrm{C}_{4}$ hydrocarbons, BTEX, TOC, PCDD/PCDF), and specific radioactivity (radioactivity per unit mass of soil). In total, 2146 soil and 145 sediment samples were analyzed, leading to a large and representative dataset for Lower Saxony. The toxicological assessment of the measured soil concentrations was performed according to the systematics of the Federal Soil Protection and Contaminated Sites Ordinance 
Fig. 4 Categories of assessment values corresponding to the German Federal Soil Protection and Contaminated Sites Ordinance
The German Federal Soil Protection and Contaminated Sites Ordinance (BBodSchV) of 12 July 1999 provides trigger values and action values pertaining to defined heavy metals and organic pollutants for three pathways: Soil ->- human being, soil - crop plants, and soil - groundwater as well as precaution values and values for admissible additional pollution loads for all pathways.

- Trigger values triggering further investigations to ascertain whether the contamination implies a danger. As a rule, specific evidence which constitutes sufficient grounds for the suspicion of an adverse soil alteration or a contaminated site shall be deemed to exist when examinations reveal an exceeding of trigger values. If there is reasonable suspicion a detailed investigation shall be conducted. The results of the detailed investigation shall be evaluated after giving due consideration to the circumstances of the individual case, especially on the basis of action values, in order to determine the extent to which measures are required.

- Action values generally indicating a danger which has to be remediate; further investigations to ascertain the danger are usually not necessary.

- Precaution values indicating a certain chance of future soil problems which need to be addressed in order to avert upcoming damages.

Table 8 Soil and groundwater screening values for specific oil and natural gas pollutants

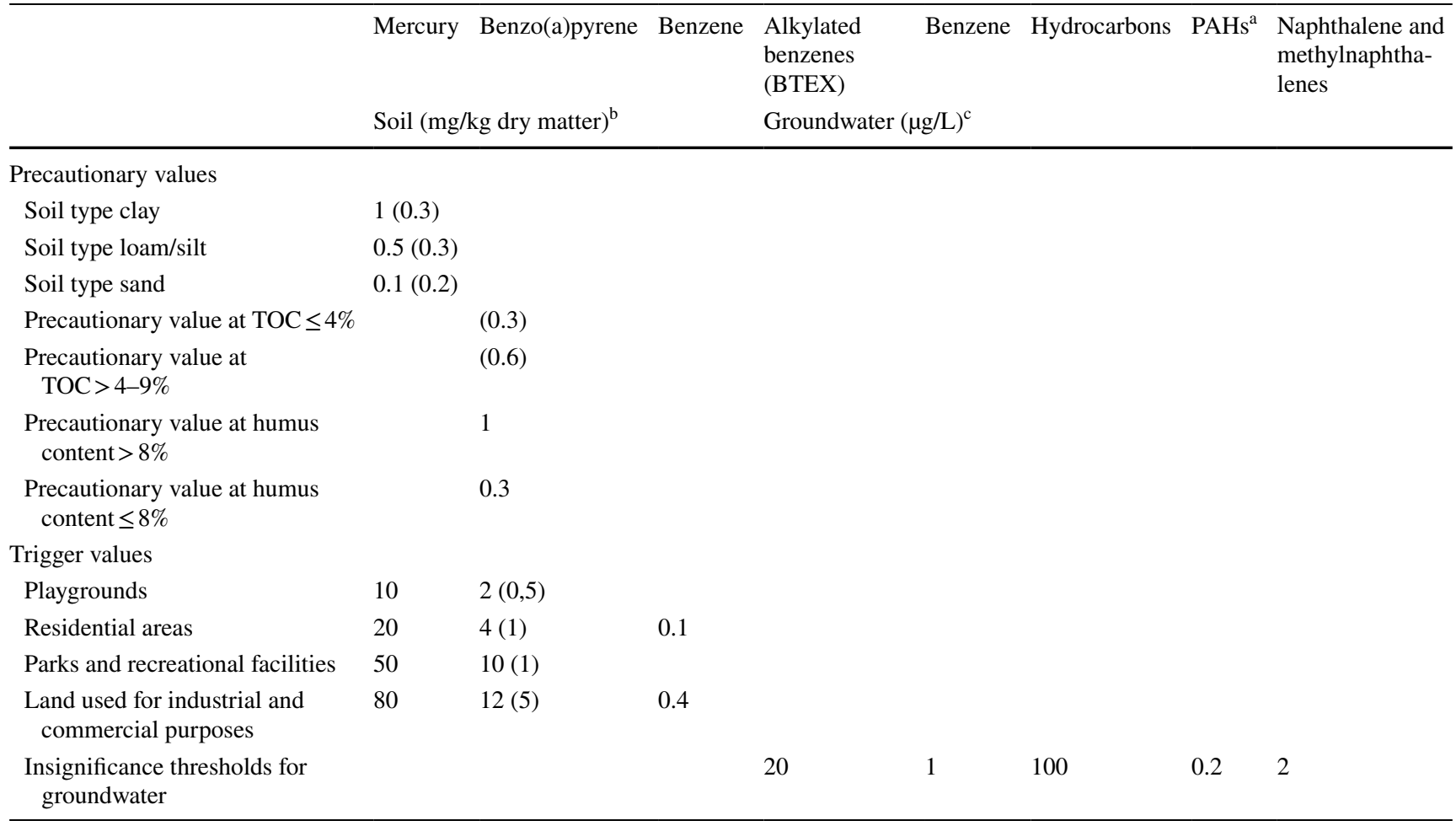

a 16 EPA PAHs without naphthalene and methylnaphthalenes

${ }^{b}$ Federal Soil Protection and Contaminated Sites Ordinance (BBodSchV) (Federal Government 1999), values in brackets: draft "Mantelverordnung" (BMU 2017)

${ }^{c}$ LAWA (2004/2017) Determination of insignificance thresholds for groundwater

(Fig. 4). The used assessment values are given in Table 8. For three of the analyzed 211 well sites, the action value for the pathway soil-agricultural plants for mercury of $2 \mathrm{mg}$ $\mathrm{Hg} / \mathrm{kg}$ soil were exceeded, with concentrations of 2.01, 2.94 and $8.14 \mathrm{mg} / \mathrm{kg}$ in three separate samples. Here, remediation was required. The trigger value for benzo(a)pyrene of $1 \mathrm{mg} / \mathrm{kg}$ soil was exceeded for eleven sites for the pathway soil-human being. At eleven sites, assessment values for mercury were exceeded in sediments from ditches. Precautionary values for mercury that depend on the type of soil range between 0.1 and $1.0 \mathrm{mg} / \mathrm{kg}$ were exceeded in $838 \mathrm{sam}-$ ples. Due to its carcinogenic properties and recent epidemiological evidence of locally increased hematological cancers, the analysis of benzene was of particular relevance. At two 
sites, benzene concentrations were $0.07 \mathrm{mg} / \mathrm{kg}$, which only slightly exceeded the limit of quantification of $0.05 \mathrm{mg} / \mathrm{kg}$. When precautionary values are exceeded, the operators of the plants must take adequate measures to avoid or minimize contaminations in future. Although several precautionary values and even action values were locally exceeded, no evidence of an extensive area-wide contamination was obtained in the environment of the studied production sites in Lower Saxony.

Recently, an epidemiological study reported an increase in early childhood leukemia in the environment of a former production site (EKN 2016). Therefore, a toxicological evaluation of environmental contaminations in this region was performed (Wollin 2016b, 2017a, b). The plant site was used as a transshipment point for crude oil and for crude oil processing between 1950 and 1995. Currently, the direct proximity of the former plant is dominated by residential buildings. The focal point of the partly considerable soil pollution with benzene, BTEX and hydrocarbons was along the hazard pathway soil-groundwater. Guideline values (Table 8) for compounds originating from crude oil in deeper soil and in groundwater were sometimes massively exceeded. Locally very high concentrations were detected for benzene (up to $1840 \mu \mathrm{g} / \mathrm{L}$ ), $\sum$ BTEX (up to $1200 \mu \mathrm{g} / \mathrm{L}$ ), hydrocarbons (up to $25,000 \mu \mathrm{g} / \mathrm{L}$ ), polycyclic aromatic hydrocarbons (up to $28.5 \mu \mathrm{g} / \mathrm{L}$ ) and naphthalene (up to $100 \mu \mathrm{g} / \mathrm{L}$ ). Nevertheless, these locally high values did not lead to increased risks for residents because the groundwater of the core area was not utilized and samples of domestic water from neighboring residential estates were not contaminated. By contrast, the parameters measured in the topsoil for the direct pathway soil-human fell below the guide values of BBodSchV in all subareas or were below the limit of quantification. Importantly, pooled soil samples did not exceed trigger values for children's playgrounds (Wollin 2016b, 2017a, b).

\section{Large-scale contamination of soil}

The use of produced water for agricultural purposes is permitted in the West of the USA, e.g., in California (Stringfellow et al. 2017b). Production water is applied for irrigation of agricultural areas, watering places for livestock, and for groundwater recharge in natural wetlands. nds in flow-back/ production water can, in principle, cause an increased risk of adverse effects in humans. HF-associated compounds could be taken up by agricultural plants or contaminate the plants via their surface. Moreover, watering of agricultural areas by production water may lead to contamination of local groundwater. In the case of non-biodegradable substances, there is a concern of (bio)accumulation. Finally, occupational exposure of farmers to production water should be considered as a further possible risk. Considering the increasing interest in using production water for agricultural purposes, these potential risks should be systematically evaluated (Stringfellow et al. 2017b). Another cause of agricultural soil contamination can be spills of HF fluids or frac chemicals, and flowback/produced water. When investigating spills with only a limited range of inorganic parameters and substances such as BTEX, and total petroleum hydrocarbons (TPHs), there is a danger that other substances will not be identified and the extent of the damage not fully recognized (McLaughlin et al. 2016). So far, little is known about the environmental behavior of frac chemicals and compounds in production water, particularly their sorption behavior, transformations and interactions. However, this knowledge is essential for the assessment of possible human risks due to the exposure paths from soil to agricultural plants, as well as from soil to groundwater. McLaughlin et al. (2016) examined the environmental fate of the widespread used HF chemicals glutaraldehyde, polyethylene glycol surfactants, and polyacrylamide-based commercial friction reducers. The polyethylene glycol tensides were found to be completely biodegradable on agricultural soil within 42-71 days. Their biodegradation was reduced in the presence of the biocidal product, glutaraldehyde. Salts, at concentrations typically occurring in production water, strongly reduced their biodegradation. The availability of glutaraldehyde in soil is reduced by adsorption to soil components; the biocide itself was completely biodegraded within 33 and 57 days. Polyacrylamide, which is used in frac fluids for friction reduction, interacts with glutaraldehyde and reduces its biodegradation (McLaughlin et al. 2016). Surfactants may increase the mobility of other organic HF additives through co-solvent effects and possibly solubilize otherwise immobile metals in the soil.

\section{Contamination of air}

\section{Air pollution}

\section{Data from the USA}

In the USA, a high fraction of greenhouse gas and volatile organic compounds (VOC) are due to oil and gas production (including conventional production). It should be noted that $\sim 1.1$ million oil and gas wells were in use in 2009 (U.S. EPA 2012). Frac operations are performed in $\sim 11,400$ new wells per year. Emissions from U.S. oil and gas activities in 2005 have been reported to be 321, 318, 510 and $619 \mathrm{kT}$ for $\mathrm{NO}_{x}, \mathrm{CO}$, NMVOCs (non-methane volatile organic compounds), and $\mathrm{SO}_{2}$, respectively (U.S. EPA 2019). By 2017 , these numbers increased to 650,637 , and $2853 \mathrm{kT}$, respectively, whereas $\mathrm{SO}_{2}$ decreased to $87 \mathrm{kT}$. In particular, the large increase in NMVOCs, including hazardous air 
pollutants, is of potential concern. Natural gas systems were the second largest anthropogenic source category of methane emissions in the U.S. in 2017, after agriculture. Overall, natural gas systems emitted 165.6 $\mathrm{MMT} \mathrm{CO}_{2}$ Eq. of methane in 2017, a 14\% decrease compared to 1990 emissions (U.S. EPA 2019). Between 2013 and 2017, the methane emissions from natural gas systems reported for the sum of the processes field production, processing, transport and storage, as well as distribution, were virtually unchanged (each with 165.6 MMT $\mathrm{CO}_{2}$ Eq. in 2013 and 2017; as well as 165.1, 167.2, and 165.7 $\mathrm{MMT} \mathrm{CO}_{2}$ Eq., respectively, in 2014, 2015 and 2016). Moreover, abandoned gas and oil drilling sites may contribute to methane emission. The fraction of abandoned sites of the total anthropogenic emission of methane has been estimated to range between 4 and $7 \%$.

Differentiation of emissions from oil and gas production and other sources, such as agriculture, traffic or landfill sites, is possible by specific patterns of VOCs (Gilman et al. 2013). It is possible to clearly identify VOC emissions that are due to oil and gas production based on the lead compounds, propane and ethyne. Using this approach, it can be estimated that approximately $55 \%$ of total VOC-OH reactivity in the USA is due to oil and gas production.

\section{Air contamination by hydraulic fracturing}

Similar to conventional oil and gas production, HF processes also lead to contamination of ambient air with methane, further aliphatic hydrocarbons, such as $\mathrm{C}_{2}-\mathrm{C}_{5}$, alkanes, VOCs, such as BTEX, hydrogen sulfide, n-hexane, and formaldehyde (Macey et al. 2014; Vinciguerra et al. 2015; Allen 2016). Recently, it has been reported that 143 air contaminants may be released due to HF (Elliott et al. 2017a). Hazard assessment by the IARC concerning carcinogenicity is available for only $20 \%$ of these compounds. Of 29 potential air contaminants, 20 compounds were known human carcinogens (IARC group 1), probably carcinogenic for humans (group 2A), or possibly carcinogenic for humans (group 2B).

Further air contaminants are generated by the peripheral plant components, including particulate matter, $\mathrm{NO}_{x}$, precursors of ozone and polycyclic aromatic hydrocarbons (Paulik et al. 2016). The following activities are known to contribute to air contamination at oil or gas drilling sites:

- Preparation of the drilling site including road connections.

- Drilling of the well.

- Truck traffic for delivery and disposal of materials.

- Removal of acid gases and water from gas; separation of natural gas from other hydrocarbons.

- Operation of compressor stations to enable the transport of natural gas into transport pipelines.

- Preprocessing of crude oil prior to refinery.
Table 9 Sources of emissions of air contaminants by HF (modified from Robinson 2014)

\begin{tabular}{llllll}
\hline Source & \multicolumn{2}{l}{ Air pollutant } & & Data quality \\
\cline { 2 - 4 } & $\mathrm{NO}_{\mathrm{X}}$ & VOC & PM & $\begin{array}{l}\text { Other toxic } \\
\text { substances }\end{array}$ \\
\hline Well development & & & & & \\
Drilling rigs & $\bullet$ & $\circ$ & $\bullet$ & $\bullet$ & Medium \\
Frac pumps & $\bullet$ & $\circ$ & $\bullet$ & $\bullet$ & Medium \\
Truck traffic & $\bullet$ & $\circ$ & $\bullet$ & $\bullet$ & Medium \\
Completion venting & & $\bullet$ & & $\bullet$ & Poor \\
Frac ponds & & $\circ$ & & & Poor \\
Gas production & & & & & \\
Compressor stations & $\bullet$ & $\bullet$ & $\circ$ & $\bullet$ & Medium \\
Wellhead compres- & $\circ$ & $\circ$ & $\circ$ & $\circ$ & Medium \\
$\quad$ sors & & & & & Medium \\
Heaters, dehydrators & & $\circ$ & $\circ$ & $\circ$ & Poor \\
Blowdown venting & & $\circ$ & & $\circ$ & Poor \\
Condensate tanks & & $\bullet$ & & $\circ$ & Poor \\
Fugitives & & & & $\circ$ & $\circ$ \\
Pneumatics & & $\circ$ & & $\circ$ & Poor \\
\hline
\end{tabular}

- Major source, ${ }^{\circ}$ minor source

- Flaring of gas.

- Volatile emissions from leaks.

- Gas release by pressure compensation.

The most important sources of air contamination are summarized in Table 9. Examples of toxic compounds reported to be released into ambient air during HF in the USA are listed in Table 10. $\mathrm{NO}_{x}$ and $\mathrm{SO}_{x}$ emissions have been reported to be higher during the development of the drilling site compared to the production phase (Colborn et al. 2014; Litovitz et al. 2013). Similar observations have been made for particulate matter (PM2.5 and PM10). Analysis of shale gas production sites in North Texas showed an increase in ozone concentrations by $8 \%$ at gas production sites compared to control sites (Ahmadi and John 2015).

A critical aspect concerning emissions of HF processes is that most emitted organic toxic compounds are not regulated. This is the case for the National Ambient Air Quality Standards (NAAQS) of the U.S. EPA according to the Clean Air Act. Here, the six so-called 'Criteria Air Pollutants' are carbon monoxide, ozone near the surface, nitrogen dioxide, particulate matter, sulfur dioxide, and lead. Since the criteria for organic air pollutants are not available in the NAAQS, the Reference Concentrations (RfCs) of the U.S. EPA (Integrated Risk Information System, IRIS) are frequently used. For carcinogenic compounds, the inhalation MRLs of the Agency for Toxic Substances and Disease Registry (ATSDR) may be applied (Macey et al. 2014). However, these scientifically derived values are not legally 


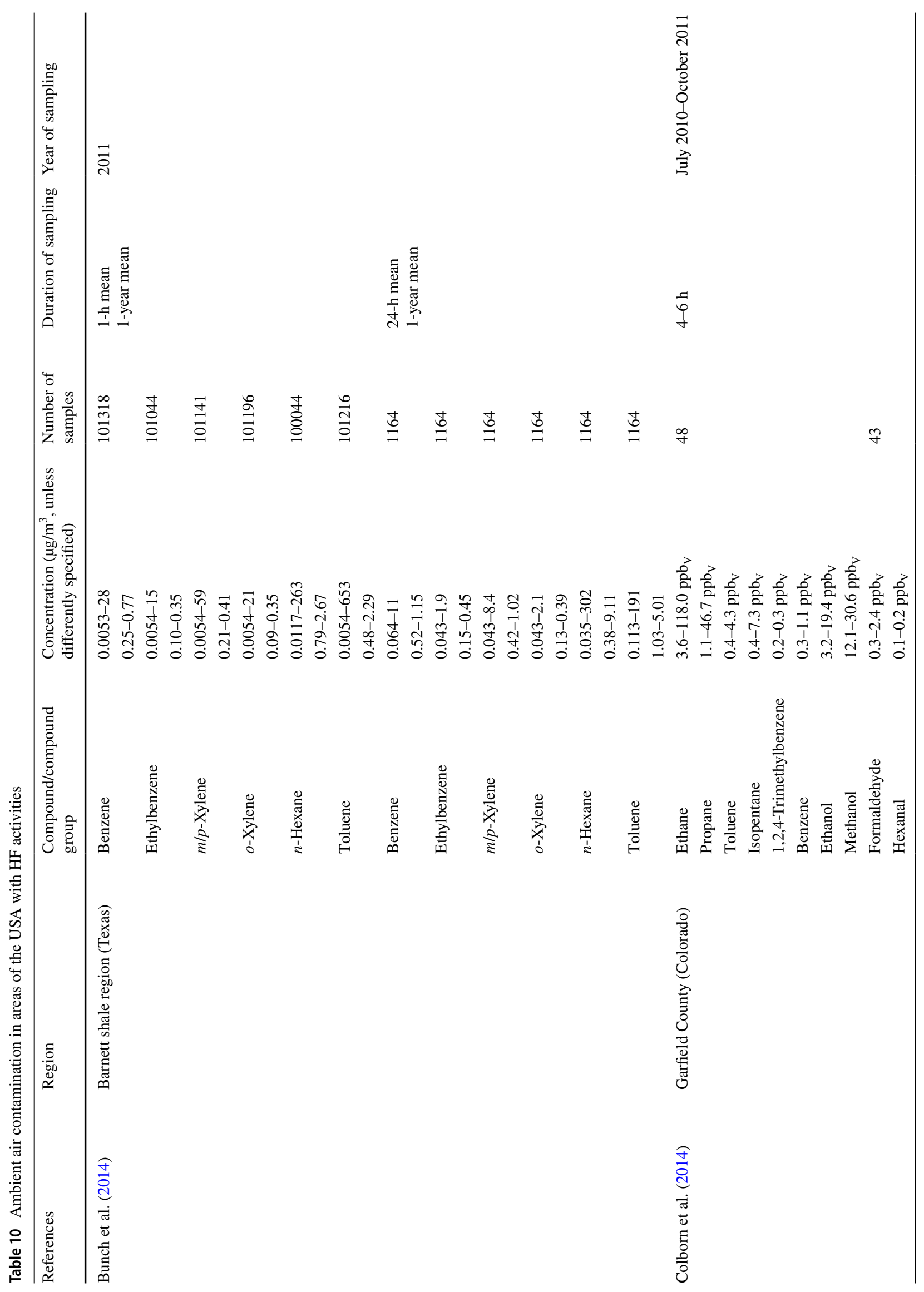


$\frac{\text { ำ }}{\stackrel{2}{8}}$

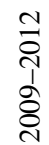

ב $\quad \frac{\text { ป }}{5}$

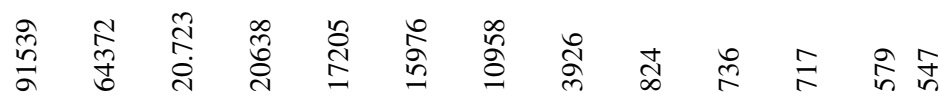

$\frac{\varrho}{\Xi}$

हुํำ

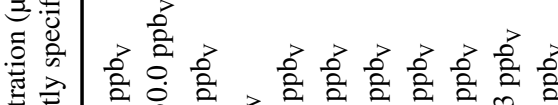

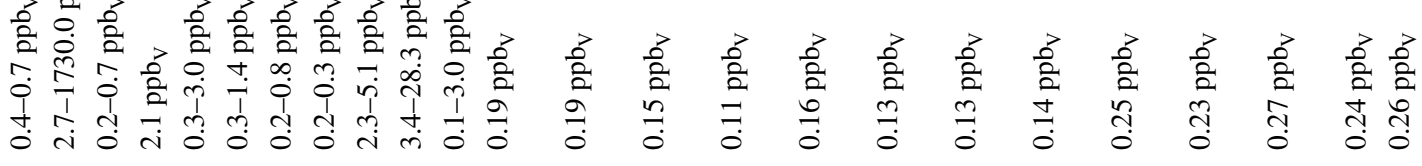

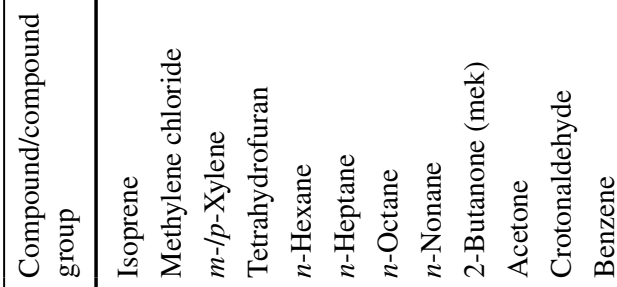

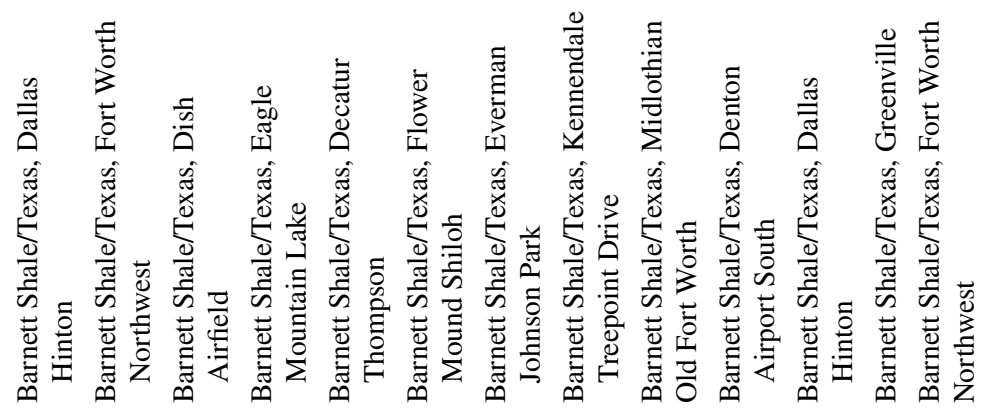

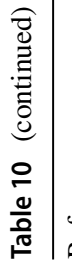

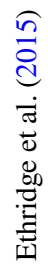




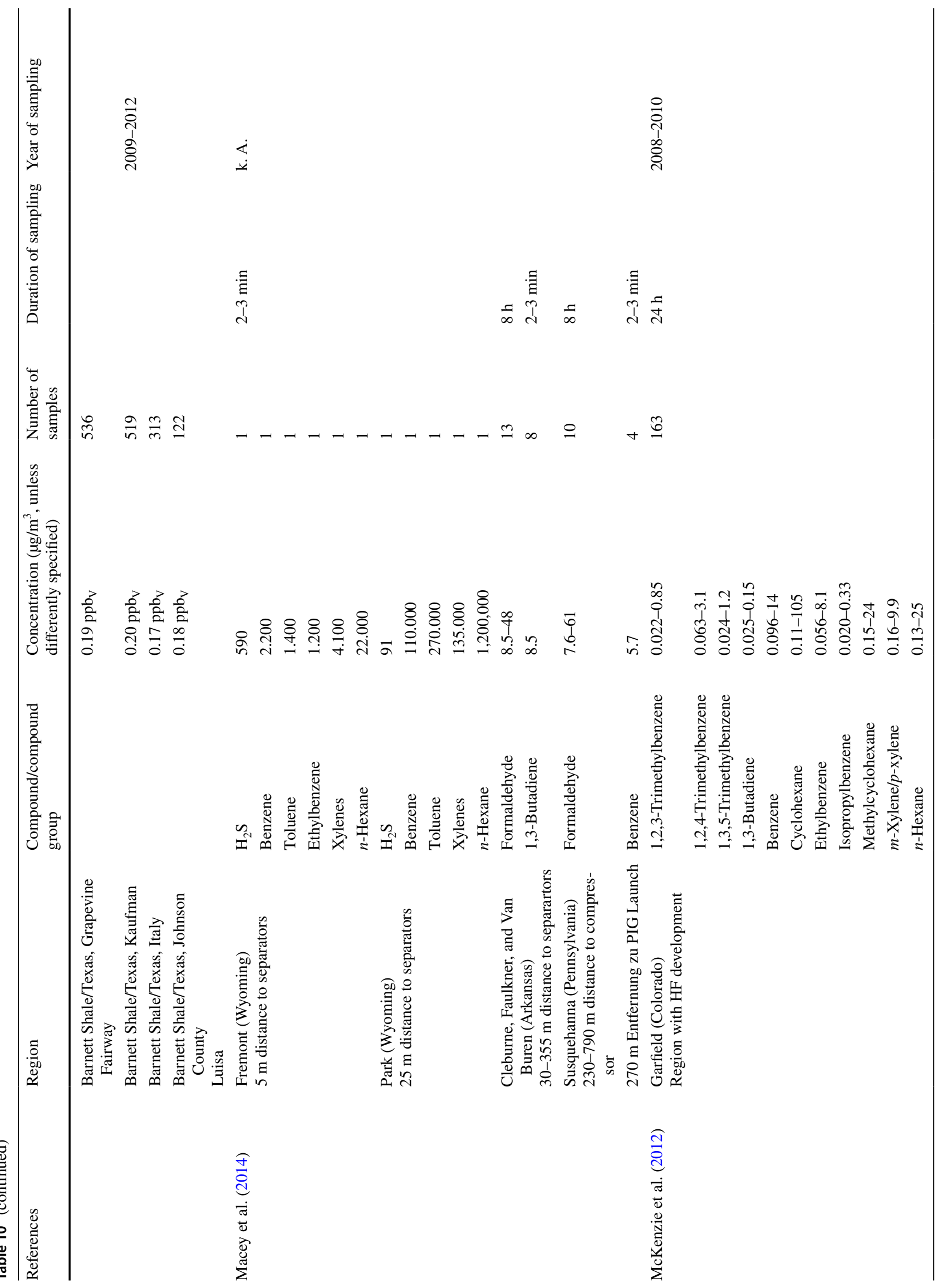




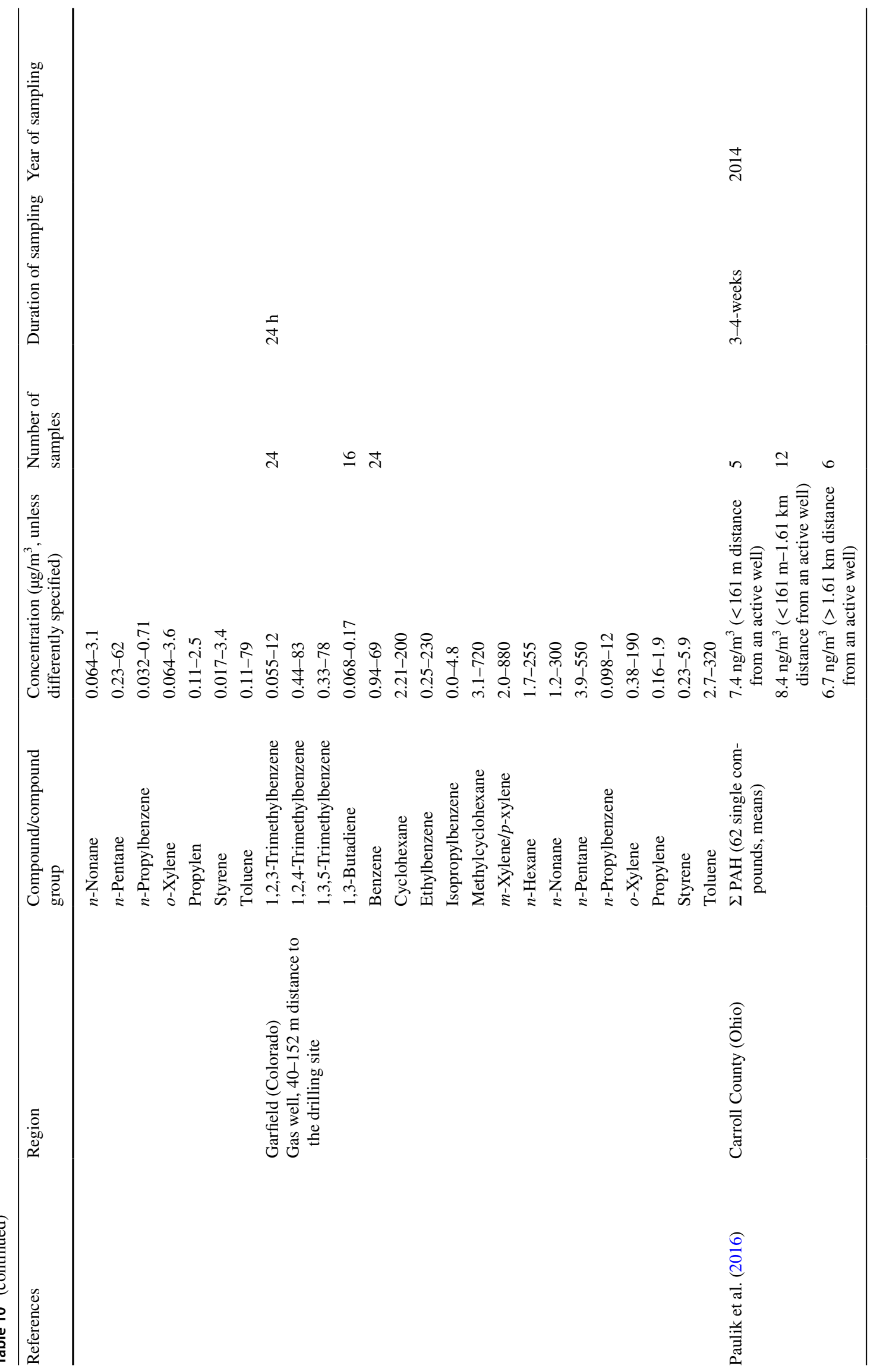




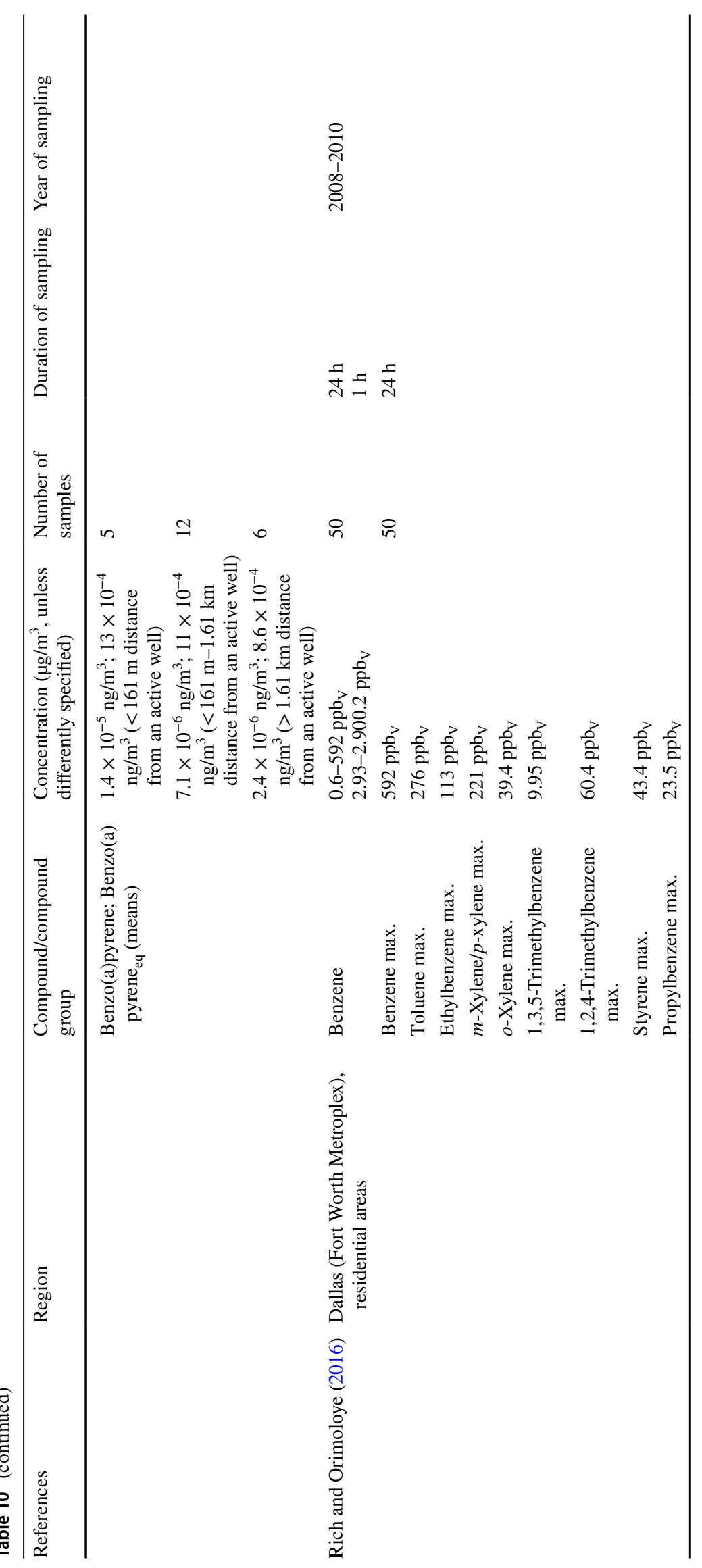


binding in the U.S. and, therefore, their current national legal regulations of toxic organic air emissions are not sufficiently comprehensive for carcinogenic compounds.

In the European Union, benzene and polycyclic aromatic compounds, with benzo(a)pyrene as a lead compound, have been regulated in the ambient air with threshold values of $5 \mu \mathrm{g} / \mathrm{m}^{3}$ and $1 \mu \mathrm{g} / \mathrm{m}^{3}$, respectively (Lilienblum and Wollin 2019). Health risks for residents in the neighborhood of HF sites still are discussed controversially. Some studies reported an increased cumulative cancer risk associated with benzene, trimethylbenzene, xylene and aliphatic hydrocarbons (McKenzie et al. 2012; Macey et al. 2014; Rich and Orimoloye 2016); however, others did not confirm these associations (Bunch et al. 2014; Ethridge et al. 2015; Paulik et al. 2016). The discrepancies may be due to high spatiotemporal variability of air concentrations during sampling (Macey et al. 2014). The challenge of adequate sampling for analysis of air contamination has already been discussed (Brown et al. 2014; Haley et al. 2016).

To adequately consider the above-described variability a specific spatially temporally resolved analysis of exposure is required, which has been applied by Ethridge et al. (2015) in the Barnett Shale in Texas. The authors used infrared cameras to obtain an overview over regions of high hydrocarbon concentrations in the air. Based on these data, locations for air sampling were identified to determine concentrations of 85 individual compounds by gas chromatography. For the final analysis more than 4.7 million individual data points were available for short- (means of $1 \mathrm{~h}, 24 \mathrm{~h}, 7$ days) and long-term (1 year and longer) analyses. In three of 1299 short-term samples, concentrations of benzene, $n$-heptane and n-octane exceeded short-term assessment values. Moreover, the odor thresholds of cyclohexane, isopentane, $m$ - and $p$-xylene, methylcyclohexane, $n$-hexane, $n$-heptane and $n$-pentane were exceeded. However, the mean values of long-term exposure levels did not exceed the respective threshold values (Ethridge et al. 2015). The authors concluded that benzene and n-hexane might be considered as particularly relevant for the evaluation of health risks. A similar result was obtained by an analysis of emission levels in the Barnett Shale, where a similarly comprehensive study was performed (Bunch et al. 2014). None of the analyzed VOCs exceeded short-term assessment values; and only in case of 1,2-dibromomethane the assessment value for chronic exposure was exceeded. Of note, the authors discussed that 1,2-dibromoethane emission was not caused by the HF procedure. According to TCEQ (2011), 1,2-dibromoethane is not a VOC that is reasonably expected to be associated with shale gas operations, but it was used as a lead scavenger in aviation fuel and off-road applications in automobile racing (U.S. EPA 2009). Significant concentrations of lead scavengers continue to persist at many old leaded gasoline spill sites.
In a further study, air samples in the neighborhood of HF development and production sites were taken by trained residents at locations identified through systematic observation of the HF operations and air impacts over the course of resident daily routines (Macey et al. 2014). Residents responded by sampling to operational conditions, odor events, and the onset of acute health symptoms. Grab air samples $(n=35)$ were taken into 10-L Tedlar bags and were analyzed for 75 VOCs, including BTEX, acrylonitrile, methylene chloride, hexane, and heptane. Additionally, formaldehyde and 20 sulfur compounds (including hydrogen sulfide and carbonyl sulfide) were analyzed using passive sampling. In 16 of the 35 Tedlar bag samples and 14 of the 41 passive samples, eight VOCs exceeded the assessment values of the ATSDR and/or the U.S. EPA IRIS RfCs. Benzene, formaldehyde and hydrogen sulfide were the most frequent compounds that exceeded short-term and chronic assessment values.

A study in Garfield County/Colorado, analyzed health risks as a consequence of air emissions due to HF in unconventional gas resources (McKenzie et al. 2012). Air samples were taken in rural residential estates or farms $(n=163)$ located either $\leq 0.8 \mathrm{~km}$ or $>0.8 \mathrm{~km}$ from gas wells, and 78 hydrocarbon compounds were analyzed. The data were used to calculate hazard indices (HIs). HIs were higher for residents living less than $0.8 \mathrm{~km}$ from wells compared to individuals living further away. The highest non-cancer HI of five was obtained for sub-chronic exposure during well completion for residents living $\leq 0.8 \mathrm{~km}$ from the gas well. This high HI was attributed to exposure to trimethylbenzene, xylenes and aliphatic hydrocarbons. Evaluation of the chronic risk accounts for exposure to air emissions from well completions and emissions from the production phase. For chronic exposure, non-cancer HIs of 1.0 were obtained for residents $\leq 0.8 \mathrm{~km}$ from wells and 0.4 for residents $>0.8 \mathrm{~km}$. For carcinogens, the lifetime cancer risk for each compound was derived by multiplying estimated exposure concentration by the inhalation unit risk. The cumulative cancer risk was estimated by the addition of the cancer risks for individual compounds. Risks are expressed as excess cancers per 1 million population based on exposure over 30 years. Cumulative cancer risk was estimated to be $10 \times 10^{-6}$ and $6 \times 10^{-6}$ for residents living $\leq 0.8 \mathrm{~km}$ as well as $>0.8 \mathrm{~km}$ from the wells.

A quantitative assessment of cancer risk due to 62 analyzed PAHs from HF emissions was performed in a rural community (Paulik et al. 2016). The obtained PAH patterns indicated that the analyzed PAHs were predominantly of petrogenic origin. The highest concentrations of benzo(a) pyrene, phenanthrene and the highest carcinogenic potential of PAH mixtures, determined as the sum of benzo(a) pyrene-equivalents of the detected PAHs, were obtained in the direct neighborhood of active wells. At these sites of maximal exposure, the additional carcinogenic lifetime risk 
Table 11 BTEX and mercury analyses at the permanent measurement point MP 01 from July 2015 to March 2016 (modified according to LBEG 2016

\begin{tabular}{|c|c|c|c|c|c|c|c|}
\hline $\begin{array}{l}\text { Sample site MP } 01 \\
\left(20^{\circ} \mathrm{C} ; 1013,25 \mathrm{hPa}\right)\end{array}$ & Month & Year & $\begin{array}{l}\text { Benzene }(\mu \mathrm{g} / \\
\left.\mathrm{m}^{3}\right)\end{array}$ & Toluene $\left(\mu \mathrm{g} / \mathrm{m}^{3}\right)$ & $\begin{array}{l}\text { Ethylbenzene } \\
\left(\mu \mathrm{g} / \mathrm{m}^{3}\right)\end{array}$ & Xylenes $\left(\mu \mathrm{g} / \mathrm{m}^{3}\right)$ & $\begin{array}{l}\text { Mercury } \\
\left(\mathrm{ng} / \mathrm{m}^{3}\right)\end{array}$ \\
\hline & July & 2015 & 0.1 & 0.3 & $<0.1$ & $<0.2$ & $\begin{array}{l}2.0 \\
1.8\end{array}$ \\
\hline & August & 2015 & 0.2 & 0.3 & 0.1 & 0.2 & $\begin{array}{l}1.3 \\
1.9\end{array}$ \\
\hline & September & 2015 & 0.2 & 0.3 & 0.1 & 0.3 & $\begin{array}{l}1.4 \\
1.4\end{array}$ \\
\hline & October & 2015 & 0.7 & 0.6 & 0.1 & 0.4 & $\begin{array}{l}1.6 \\
1.5\end{array}$ \\
\hline & November & 2015 & 0.3 & 0.4 & 0.1 & 0.3 & $\begin{array}{l}1.7 \\
1.3\end{array}$ \\
\hline & December & 2015 & 0.4 & 0.4 & 0.1 & 0.4 & $\begin{array}{l}1.5 \\
1.4\end{array}$ \\
\hline & January & 2016 & 0.9 & 0.6 & 0.1 & 0.4 & $\begin{array}{l}1.5 \\
1.7\end{array}$ \\
\hline & Februar & 2016 & 0.5 & 0.4 & 0.1 & 0.3 & $\begin{array}{l}1.7 \\
1.7\end{array}$ \\
\hline & March & 2016 & 0.4 & 0.4 & 0.1 & 0.2 & n.a. \\
\hline Arithmetic mean & & & 0.4 & 0.4 & 0.1 & 0.3 & 1.6 \\
\hline \multirow[t]{3}{*}{ Assessment value } & & & $5^{\mathrm{a}}$ & $5.000^{\mathrm{b}}$ & $1.000^{c}$ & $100^{\mathrm{d}}$ & \\
\hline & & & & $3.800^{\mathrm{e}}$ & $260^{f}$ & $217^{\mathrm{g}}$ & \\
\hline & & & & $30^{\mathrm{h}}$ & & $30^{\mathrm{i}}$ & $50^{\mathrm{k}}$ \\
\hline
\end{tabular}

${ }^{\mathrm{a}}$ Limit value (Directive 2008/50/EC); ${ }^{\mathrm{b}} \mathrm{RfC}$ (IRIS U.S. EPA 2020); ${ }^{\mathrm{c}} \mathrm{RfC}$ (IRIS U.S. EPA 2020); ${ }^{\mathrm{d}} \mathrm{RfC}$ (IRIS U.S. EPA 2020); ${ }^{\mathrm{e}}$ chronic inhalation MRL (ATSDR 2019); ${ }^{\mathrm{f}}$ chronic inhalation MRL (ATSDR 2019); ${ }^{\mathrm{g}}$ chronic inhalation MRL (ATSDR 2019); ${ }^{\mathrm{h}}$ Target value of the air purity guidelines (LAI 1997); ${ }^{\text {T}}$ Target value of the air purity guidelines (LAI 1997); ${ }^{\mathrm{k}}$ Guidance value mercury (LAI 2004)

was estimated to be $0.04 \times 10^{-6}$ and, therefore, fell below the additional carcinogenic lifetime risk of $1 \times 10^{-6}$ that the U.S. EPA considered as acceptable.

McMullin et al. (2018) analyzed exposure to VOCs emitted from exploitation regions with HF in Colorado. The authors identified 56 VOCs and compiled 47 existing air monitoring datasets that measured these VOCs in 34 locations across the exploitation regions. Based on the measured air concentrations, acute and chronic exposures were estimated by comparing exposures to health guideline levels using maximum and mean air concentrations. Selecting acute and chronic non-cancer health guidance values followed a tiered approach using U.S. EPA's RfCs and Unit Risk estimates in the first line. Acute and chronic non-cancer hazard quotients were below one for all individual VOCs at distances of 500 feet $(0.152 \mathrm{~km}$, the current setback distances from new wells in the state Colorado) or greater from production sites. Hazard indices combining exposures for all VOCs were slightly above one. The lifetime excess cancer risk estimates for benzene were between $1.0 \times 10^{-5}$ and $3.6 \times 10^{-5}$ and ethylbenzene was $7.3 \times 10^{-6}$.

\section{Data from Germany}

In Germany, $2.106 \mathrm{kt}$ of methane were emitted in 2018, which corresponds to $52.642 \mathrm{kt} \mathrm{CO}_{2}$-eq. (Eionet 2020). These emissions changed only little since 2011. Similar to the USA, agriculture in Germany contributes the largest fraction $(61.8 \%)$ of methane emissions. Emissions of methane due to oil, gas, iron and steel production in Germany have been estimated to be very low to negligible (UBA 2017; Eionet 2020).

Several pilot studies of exposure to VOCs and mercury due to HF in Germany have been performed. Data from a gas drilling site in Rotenburg (Wümme) obtained between July 2015 and March 2016, a period during which flaring of gas was also performed, did not exceed the EU-emission limit value of benzene $\left(5 \mu \mathrm{g} / \mathrm{m}^{3}\right)$ (LBEG 2016). The assessment values of TEX and the guidance value of mercury of $50 \mu \mathrm{g} /$ $\mathrm{m}^{3}$ (LAI 2004) were also not exceeded (Table 11). Benzene air concentration ranges were clearly below the EU-emission limit value and values were in line with those that are typically observed in rural and urban regions of Germany (GAA Hildesheim 2019). Similar results were obtained near a gas production site in Bellen, Söhlingen in 2012, in which the arithmetic means of 6-monthly average values were $0.5 \mu \mathrm{g} /$ 
Table 12 Additional BTEX load in the immission (ZUS LLG 2016)

\begin{tabular}{|c|c|c|c|c|c|c|c|c|}
\hline \multirow[t]{2}{*}{ BUP } & \multicolumn{2}{|c|}{ Benzene $\left(\mu \mathrm{g} / \mathrm{m}^{3}\right)$} & \multicolumn{2}{|c|}{ Toluene $\left(\mu \mathrm{g} / \mathrm{m}^{3}\right)$} & \multicolumn{2}{|c|}{ Ethylbenzene $\left(\mu \mathrm{g} / \mathrm{m}^{3}\right)$} & \multicolumn{2}{|c|}{ Xylenes $\left(\mu \mathrm{g} / \mathrm{m}^{3}\right)$} \\
\hline & Min. & Max. & Min. & Max. & Min. & Max. & Min. & Max. \\
\hline $\mathrm{X}_{1}$ & 3.62 & 4.12 & 0.44 & 0.61 & 0.02 & 0.05 & 0.02 & 0.06 \\
\hline $\mathrm{X}_{2}$ & 0.64 & 0.72 & 0.08 & 0.11 & $<0.01$ & 0.01 & $<0.01$ & 0.01 \\
\hline $\mathrm{X}_{3}$ & 0.82 & 0.94 & 0.10 & 0.14 & $<0.01$ & 0.01 & 0.01 & 0.01 \\
\hline $\mathrm{X}_{4}$ & 0.95 & 1.11 & 0.12 & 0.17 & $<0.01$ & 0.01 & 0.01 & 0.02 \\
\hline $\mathrm{X}_{5}$ & 1.75 & 2.19 & 0.22 & 0.33 & 0.01 & 0.02 & 0.01 & 0.03 \\
\hline
\end{tabular}

$\mathrm{m}^{3}, 0.6 \mu \mathrm{g} / \mathrm{m}^{3}$ and $0.5 \mu \mathrm{g} / \mathrm{m}^{3}$ at three sampling points. A relevant influence of plant operations on emissions was not observed in this study.

Epidemiological studies showed increased early childhood leukemias in the neighborhood of a cold-gas flare installation in Germany that was operated until 1989 (EKN 2016). Analyses in 1988 showed that benzene mass concentrations were exceeded by factors of 333-380 in the exhaust gas. Benzene mass flow was exceeded by factors of 4.0-4.5 (TÜV Hannover 1988). An immission analysis of BTEX was performed in 2016 (Wollin 2017a, b; ZUS LLG 2016), in which data were obtained for five assessment points that corresponded to directly adjacent residential estates (Table 12). The distance of these residential estates to the cold-gas flare was only 100-300 $\mathrm{m}$. The predicted total benzene load in the immission estimated as the sum of the predicted additional benzene load in the immission and the background ranged between 1.42 and $4.82 \mu \mathrm{g} / \mathrm{m}^{3}$. The background level of $0.7 \mu \mathrm{g} / \mathrm{m}^{3}$ for rural areas (LAI 1992) was used to estimate the additional contribution of the cold-gas flare. This showed that the current, legally binding, maximum emission limit value of benzene $\left(5 \mu \mathrm{g} / \mathrm{m}^{3}\right)$ was not exceeded at any point of analysis. However, in the case of the maximally detected concentration of $4.82 \mu \mathrm{g} / \mathrm{m}^{3}$, the benzene threshold was almost reached. It should be considered that measurements of emissions in the ambient air could only be used for an approximate estimation of average exposure in relation to the distance from production sites. There may also be a variety of sources of emissions measured, not only the pollutants arising from gas or oil production (Zielinska et al. 2014), and they may not accurately describe the exposure of individuals.

\section{Hydraulic fracturing and human health risks}

Quantitative assessment of toxicological risks of HF should include all upstream processes, such as production and transport of the required frac chemicals; onsite activities, such as storage of chemicals, production water; drilling and downstream processes, such as the processing of hydrocarbons and production water. Health risks for humans may also occur via environmental contamination or direct exposure at working places (Adgate et al. 2014; Goldstein et al. 2014).

In some cases, human health risks have been exclusively based on data of acute toxicity (Stringfellow et al. 2014, 2017a). However, human risk evaluation of HF-associated processes should not be limited to the analysis of the inherent acute and chronic toxicity of chemicals in frac fluids or components of the flow-back, i.e., the hazard of the individual compounds (Stringfellow et al. 2014, 2017a, b; Elliott et al. 2017a, b; Wattenberg et al. 2015; Webb et al. 2014; Bergmann et al. 2014; Meiners et al. 2012a, b; Meiners 2012; Yost et al. 2016). In fact, the identification of inherent toxicity (hazard) represents a first and essential step in risk evaluation (NRC 1983, 2009; Wattenberg et al. 2015). Here, substances with the properties carcinogenic, mutagenic [e.g., Kahrilas et al. 2015; Elliott et al. 2017a (review)] and toxic to reproduction/developmental toxicity (Webb et al. 2014; Elliott et al. 2017b) as well as compounds with endocrine activities or endocrine disruptors (Kassotis et al. 2014) are of central interest.

It should be kept in mind that risk characterization represents the final step of the risk assessment procedure and is the basis of risk management (Wollin and Illing 2014). This means that the sole presence of a hazardous compound at working places or in a specific environmental compartment does not necessarily mean a health risk for humans; rather, it should be linked to a specific exposure (Saunders et al. 2018). Risk characterization focusses on the question of whether a specific external exposure leads to internal concentrations at target cells of toxicity that are high enough to cause adverse effects.

An alternative to risk assessment is the precautionary principle (Commission of the European Communities 2000). The precautionary principle in risk management requires a scientific assessment as far as possible and the identification of the degree of scientific uncertainty. An assessment is required of the consequences that would occur if no action is taken. Once the results of the scientific risk assessment are available, persons concerned should be involved in the examination of precautionary measures.

The public discussion about HF focused on health risks caused by chemicals that can be part of frac fluids, additives or compounds in the flow-back, as well as produced 
water. Moreover, emissions have been increasingly considered. Assessment of human risks can be performed based on legal limit values or health guidance values. If such values are not available, further principles may be applied, such as thresholds of toxicological concern (TTC) (assessment values for compounds with unknown toxicity), or the precautionary concept of Health-related Indication Values (HRIV) in Germany (Dieter 2014).

\section{Epidemiological studies of adverse health effects associated with HF}

Only few epidemiological studies have been performed to specifically analyze the health consequences of HF. The vast majority of studies focused on conventional oil and gas production. Recently, several review articles focusing on health and environmental risks of HF have been published. One review (Werner et al. 2015) identified more than 1000 studies published between 1995 and March 2014 (peer-reviewed and gray literature); after analysis and filtering using defined inclusion criteria, only 109 studies remained, of which only seven were considered as highly relevant. The inclusion criteria rank the strength of evidence of health impact that is related to/caused by environmental hazards released by HF activities, which included qualitative and/or quantitative studies. Most publications focus on the consequences of HF for water and air, while consequences for human health were deduced indirectly but were not directly proven. Moreover, most studies focus on acute and not chronic toxicity, such as cancer or reproductive toxicity. It was concluded that direct scientific evidence of associations between HF and adverse effects in humans is missing; vice versa, adverse effects can also not be excluded. This uncertainty leads to an unsatisfactory situation concerning public health (Werner et al. 2015).

A second review was performed based on 685 original publications with peer review, published between January 2009 and December 2015 (Hays and Shonkoff 2016). They identified reports of increased hazard and adverse effects in $84 \%$ of the studies on public health; positive associations or contamination was reported in $69 \%$ of the studies on water quality; increased emissions of air pollutants in $87 \%$ of studies about the quality of air (Hays and Shonkoff 2016). The authors critically discuss the limitations of their review, including the binary categorization of the analyzed studies and the lack of analysis of the quality of study design, methods and implementation. The assessment of the scientific literature provides a general understanding of the weight of the scientific evidence of possible health impacts and can be used to prioritize future research, and to provide an empirical foundation for policy decisions (Hays and Shonkoff 2016).

A third scoping review analyzed 216 studies with a scientific peer review published between 2000 and September 2017 that focused on health effects of HF in the USA (Wright and Muma 2018). The authors excluded studies that exclusively presented stakeholder perceptions and finally identified 18 publications that fulfilled their criteria. Unlike full systematic reviews or meta-analyses, the authors did not aim to evaluate the quality of the studies. Three of the 18 studies did not focus on toxicological and/or environmental toxicological aspects but addressed risks at working places due to the upstream production of proppants. Ten studies identified statistically significant associations between HF and specific human health issues; six reported evidence for associations, while two did not identify any association.

Five of six studies on maternal, neonatal and childhood health reported inconsistent results; whereas, a further one found no such relationship. In the retrospective cohort study of 15,451 live births in Southwest Pennsylvania from 2007 to 2010, no significant association of proximity and density of HF with prematurity was found (Stacy et al. 2015). A comparison between the most and the least exposed women, however, revealed lower birth weights $(3323 \pm 558$ vs $3344 \pm 544 \mathrm{~g}$ ) and a higher incidence of the outcome small for gestational age (6.5 vs $4.8 \%$, respectively; odds ratio 1.34; $95 \%$ CI 1.10-1.63). The clinical significance of the differences in birth weight among the exposure groups is unclear since a birth weight of less than $2500 \mathrm{~g}$ is usually considered to be critical. The findings further emphasize a more precise and accurate characterization of exposure over an extended time period to evaluate the potential health significance of HF (Stacy et al. 2015). A similar retrospective cohort study using electronic health record data on 9384 mothers living close to HF sites linked to 10,946 neonates from January 2009 to January 2013 found a positive relationship between HF activity and premature births that increased as mothers' exposure to activity increased (fourth quartile odds ratio 1.4 (95\% CI 1.0, 1.9) (Casey et al. 2016). Post hoc analysis identified a positive relationship between HF and physician-identified high-risk pregnancy. The inverse-distance squared model to characterize exposure incorporated distance to the mother's home; dates and durations of well pad development, drilling, and hydraulic fracturing; and production volume during pregnancy (Casey et al. 2016). In a further retrospective cohort study of 124,842 births between 1996 and 2009 in rural Colorado, an increasing prevalence of congenital heart defects with an odds ratio of 1.3 for the highest tertile (95\% CI 1.2, 1.5) has been estimated (McKenzie et al. 2014). Neural tube defects prevalence was associated with the highest tertile of exposure (OR 2.0; 95\% CI 1.0, 3.9, based on 59 cases), compared with the absence of any gas wells within a 10-mile radius. Exposure was negatively associated with preterm birth and positively associated with fetal growth, although the magnitude of association was small. No association was found between exposure and oral clefts. An inverse distance weighted approach 
was applied to estimate maternal exposure which accounts for the number of wells within the 10-mile radius of the maternal residence, as well as distance of each well from the maternal residence. The authors concluded that greater specificity in exposure estimates is needed to further explore these associations (McKenzie et al. 2014). A retrospective birth cohort study among 158,894 women with a birth or fetal death from November 2010 to November 2012 in the Barnett Shale (North Texas) found increased adjusted odds of preterm birth associated with HF activity in the highest tertiles of the 0.5- (OR 1.14; 95\% CI 1.03, 1.25), 2- (OR 1.14; CI 1.07, 1.22), and 10-mile (OR 1.15; CI 1.08, 1.22) metrics (Whitworth et al. 2017). Increased adjusted odds of fetal death were found in the second tertile of the 2-mile metric (OR 1.56; CI 1.16, 2.11) and the highest tertile of the 10-mile metric (OR 1.34; CI 1.04-1.72). Little indication of an association with SGA or term birthweight was found.

Analysis of cancer risk showed an increased incidence of urinary bladder cancer in females and males over time (Finkel et al. 2016). Moreover, thyroid cancer in females and males and leukemia increased over the examined time periods in all counties; however, this increase occurred regardless of HF activities. The incidence of childhood leukemia was reported to be increased by more than fourfold for the age group of 5-24 years in a rural region of Colorado (McKenzie et al. 2017). However, no increase in childhood leukemia was obtained for children up to 4 years. Additionally, non-Hodgkin lymphoma was not increased in children or adults.

In the 15 studies, mostly indirect measures of exposure were used, such as the number of gas wells or distance between places of residence and production sites. Exceptions were the occupational study of Esswein et al. (2014) and the public health study of Steinzor et al. (2013) which also reported data of airborne exposure, groundwater tests and inner exposure. These will be described in more detail below. Steinzor et al. (2013) performed a self-reporting health survey and environmental testing project between August 2011 and July 2012 that involved 108 individuals in 55 households in 14 counties across Pennsylvania. For 18 of the 20 symptoms (i.e., sinus problems, nasal irritation, increased fatigue, feeling weak and tired, joint pain, and shortness of breath), a higher percentage of those living within 1500 feet of a gas extraction and production facility experienced the symptom than of those living further away. Furthermore, a total of 34 air tests with a $24 \mathrm{~h}$ sampling time and nine water tests were conducted at 35 households. A total of 19 VOCs were detected in the ambient air sampled outside homes. The maximum concentration of 'Total Hydrocarbons' was $146 \mu \mathrm{g} / \mathrm{m}^{3}$; with benzene, toluene, ethylbenzene and $o$-xylene and the sum of $m-/ p$-xylene reaching maxima of $1.5 \mu \mathrm{g} / \mathrm{m}^{3}, 7.9 \mu \mathrm{g} / \mathrm{m}^{3}, 1.5 \mu \mathrm{g} / \mathrm{m}^{3}, 1.9 \mu \mathrm{g} /$ $\mathrm{m}^{3}$ and $5.2 \mu \mathrm{g} / \mathrm{m}^{3}$, respectively. Among the halogenated hydrocarbons analyzed, methylene chloride ranked highest, with a maximum concentration of $32.62 \mu \mathrm{g} / \mathrm{m}^{3}$, followed by tetrachloroethylene and trichloroethylene, with maxima of $10.85 \mu \mathrm{g} / \mathrm{m}^{3}$ and $5.37 \mu \mathrm{g} / \mathrm{m}^{3}$, respectively. Maximum concentrations of the ketones 2-butanone and acetone were 2.9 and $19 \mu \mathrm{g} / \mathrm{m}^{3}$. Iron, manganese, arsenic, and lead were detected in the nine water well samples at levels that partly exceeded drinking water MCLs. The authors discussed associations between the chemicals measured in air and water and the health symptoms reported by residents predominantly in a plausible qualitative manner. Many of the chemicals quantitatively measured are known to be related to oil and gas operations and to the health symptoms. By contrast, the analyzed ambient air levels were, in part, below guidance values for acute and chronic exposure and due to the single $24 \mathrm{~h}$ sampling only reflects a snap-shot of the effects. The origin of the chemicals contributing to the overall impairment to air and water can also come from sources other than HF. Esswein et al. (2014) investigated the exposure of workers during flow-back operations in unconventional oil and gas extraction using real-time measurements to characterize air peak concentrations in various workplace areas, especially for VOCs and benzene. Urinary $S$-phenyl mercapturic acid (S-PMA) was used as a marker for benzene inner body burden. Airborne concentrations of hydrocarbons, including benzene, fluctuate greatly. Benzene was identified as the primary VOC exposure hazard for workers. Full-shift personal breathing zone benzene samples [time-weighted average (TWA)] from four different sites ranged from 0.007 to $0.59,0.11$ to $0.17,0.02$ to 0.50 , and 0.004 to $0.02 \mathrm{ppm}$, respectively, and partly exceeded NIOSH's OEL (occupational exposure limit) of $0.1 \mathrm{ppm}$ benzene (Recommended Exposure Limit, REL-TWA). The arithmetic mean of urinary S-PMA from workers performing tank gauging was $6.5 \mu \mathrm{g} / \mathrm{g}$ creatinine (SD $5.5 \mu \mathrm{g} / \mathrm{g}$ creatinine). By contrast, the arithmetic mean of S-PMA in urine from workers not gauging tanks was $3.1 \mu \mathrm{g} / \mathrm{g}$ creatinine (SD $3.7 \mu \mathrm{g} / \mathrm{g}$ creatinine). Although sample numbers were limited and no correction for smoking was made, S-PMA in the urine of workers was moderately correlated with full-shift personal breathing zone benzene TWA concentrations $(r=0.56)$. While detectable concentrations of S-PMA were measurable in the urine of workers, none of the samples exceeded the ACGIH Biological Exposure Index (BEI) of S-PMA of $25 \mu \mathrm{g} / \mathrm{g}$ creatinine.

A systematic review of the existing epidemiologic literature on potential adverse health outcomes in populations living near oil and natural gas operations (ONGs) in the USA was performed by Bamber et al. (2019). The authors defined ONGs (or development) to include all upstream processes involved in the extraction of ONG resources using any combination of vertical drilling, directional/horizontal drilling, and hydraulic fracturing to access oil and natural gas from conventional and unconventional geologic formations. The 
evaluation of key studies to determine the level of certainty was based on 14 questions relating to population and sample, exposure, health outcomes, confounders, and reporting. Study findings were rated as having low, moderate, or high certainty that the estimated effect was close to that of the true effect. Among the 20 research articles, the level of certainty of four studies was rated as moderate and the level of all others as low. For each health outcome, weight-of-evidence levels were determined as substantial, moderate, limited, mixed, failing to show an association, or insufficient. The weight-of-evidence for studies on birth defects was assessed as insufficient, but as mixed for the birth outcomes decreased term birth weight or low birth weight, low APGAR score, preterm/premature birth, and small for gestational age; whereas, early infant mortality, fetal death, gestation period, and low infant health index were assessed as insufficient. The weight-of-evidence for the different cancer endpoints was overwhelmingly rated as insufficient (non-Hodgkin's lymphoma (childhood), CNS tumors (child), urinary bladder, thyroid, and leukemia). The exception was leukemia (childhood non-specific and acute lymphocytic leukemia), for which the evidence was mixed. The weight-of-evidence was also assessed as mixed for the health outcomes: cardiovascular (hospitalizations), dermal (self-reported symptoms), psychological (self-reported symptoms), and respiratory (self-reported symptoms, hospitalizations). By contrast, self-reported cardiovascular symptoms, neurological (hospitalizations), psychological (diagnosed sleep disturbances), and "Others" (all hospitalizations) have been evaluated as insufficient. Self-reported gastrointestinal symptoms and self-reported neurological symptoms were classified as limited-failing to show an association. The authors concluded that the 20 studies with 32 different health outcomes of residents living near ONG operations analyzed in the review provide limited evidence (modest scientific findings that support the outcome, but with significant limitations) of harmful health effects, including asthma exacerbations and various self-reported symptoms. For all other health outcomes, conflicting evidence (mixed), insufficient evidence, or in some cases, a lack of evidence of the possibility for harmful health effects have been found. A summary of key messages of epidemiological research articles considered in the above-mentioned review articles is given in Table 13.

In principle, it could be expected that adverse health effects due to HF are more severe compared to conventional gas and oil production since HF can cause exposure to a higher number of toxic compounds, including those exhibiting endocrine activity (Balise et al. 2016). Therefore, the quality of exposure assessment is crucial. Most exposure estimates in epidemiological studies on HF are based on sophisticated but indirect distance measurements or HF activity metrics and not on measured contaminant concentrations in ambient/indoor air, soil, groundwater, and drinking water. A recent study compared exposure categories based on ambient air measurements between 2011 and 2015 and estimates of distance-based well activity metrics for each phase of well development (pad preparation, drilling, fracturing, and production) (Wendt Hess et al. 2019). Daily mean air monitoring data for benzene, carbon monoxide, nitrogen dioxide, ozone, fine particulates and sulfur dioxide were combined with data on 8885 wells in Pennsylvania. Ambient air samples of the six pollutants were collected at 76 monitoring sites. The results suggest that the well activity metrics do not adequately distinguish categories of air pollutant exposure and calculated exposure estimates did not agree with those from air sampling data. Using distance-based well activity metrics as surrogate for ambient air exposure can result in misclassification.

Apart from general limitations in terms of bias (including confounding), use of human studies is complicated due to the occurrence of other co-exposures and the fact that unexposed individuals usually do not exist. The variability in terms of susceptibility to chemical exposures and interaction with other lifestyle factors means that results from different epidemiological studies can be conflicting (Lanzoni et al. 2019). However, epidemiological studies of sufficient size and quality that include precise exposure monitoring are not yet available. It has been concluded that there is an urgent need for high-quality epidemiological studies to assess possible adverse health effects of HF (Rabinowitz et al. 2015; Saunders et al. 2018; SCHEER 2018; Wright and Muma 2018; Bamber et al. 2019).

\section{Epidemiological studies in regions with unconventional oil and gas production in Germany}

Suspected local cancer clusters in the neighborhood of natural gas or oil production facilities with former frac operations (LBEG 2019b) prompted advanced cancer cluster investigations in several regions of Lower Saxony. The focus lay on hematological malignancies according to ICD-10 (C81-C96) (EKN 2014, 2015, 2016; LK Rotenburg 2017). A statistically significant increase in the incidence of leukemia and lymphoma (ICD-10 C81-C96) was observed in men of the joint community of Bothel in the district of Rotenburg; 41 cases were observed and 21.3 expected (SIR: 1.93; 95\% CI 1.38-2.61) (EKN 2014). An analysis of sub-groups of leukemia and lymphoma (C81-C96) showed the strongest increase for multiple myelomas (C90), non-Hodgkin lymphomas (C82-C85), followed by leukemias (C91-C95) and Hodgkin lymphomas (C81). In contrast to men, only 15 leukemia and lymphoma cases were observed for women. 


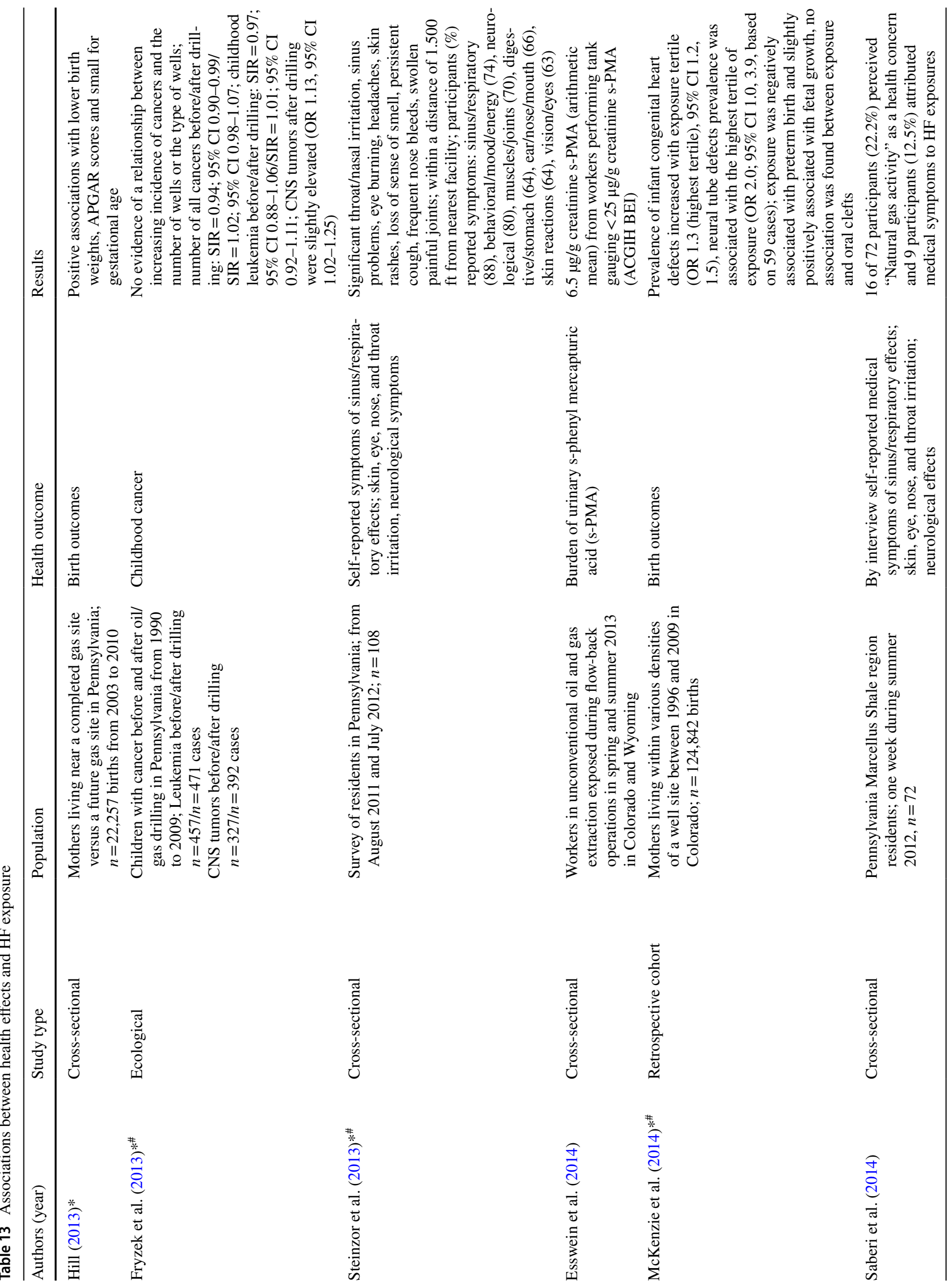




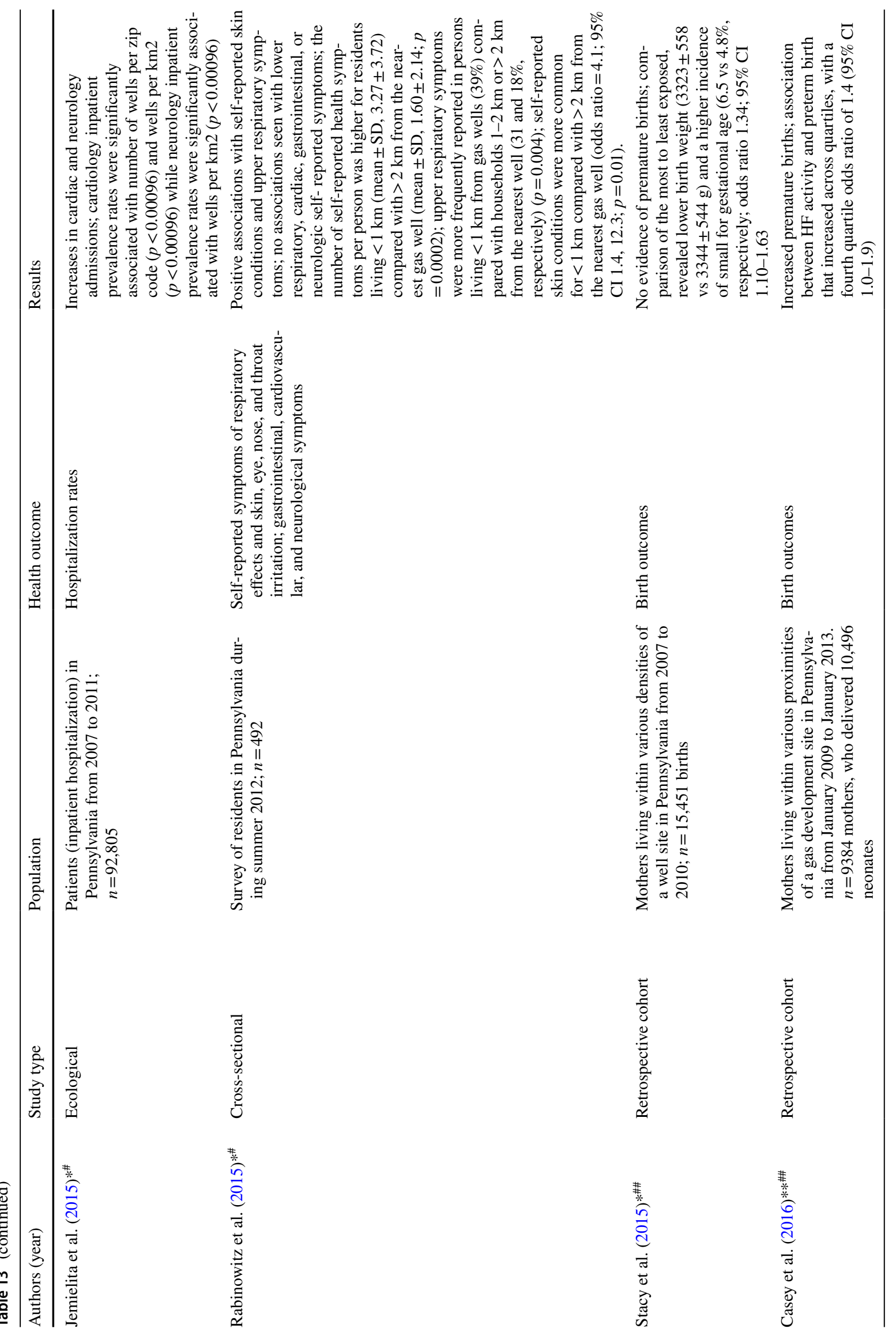




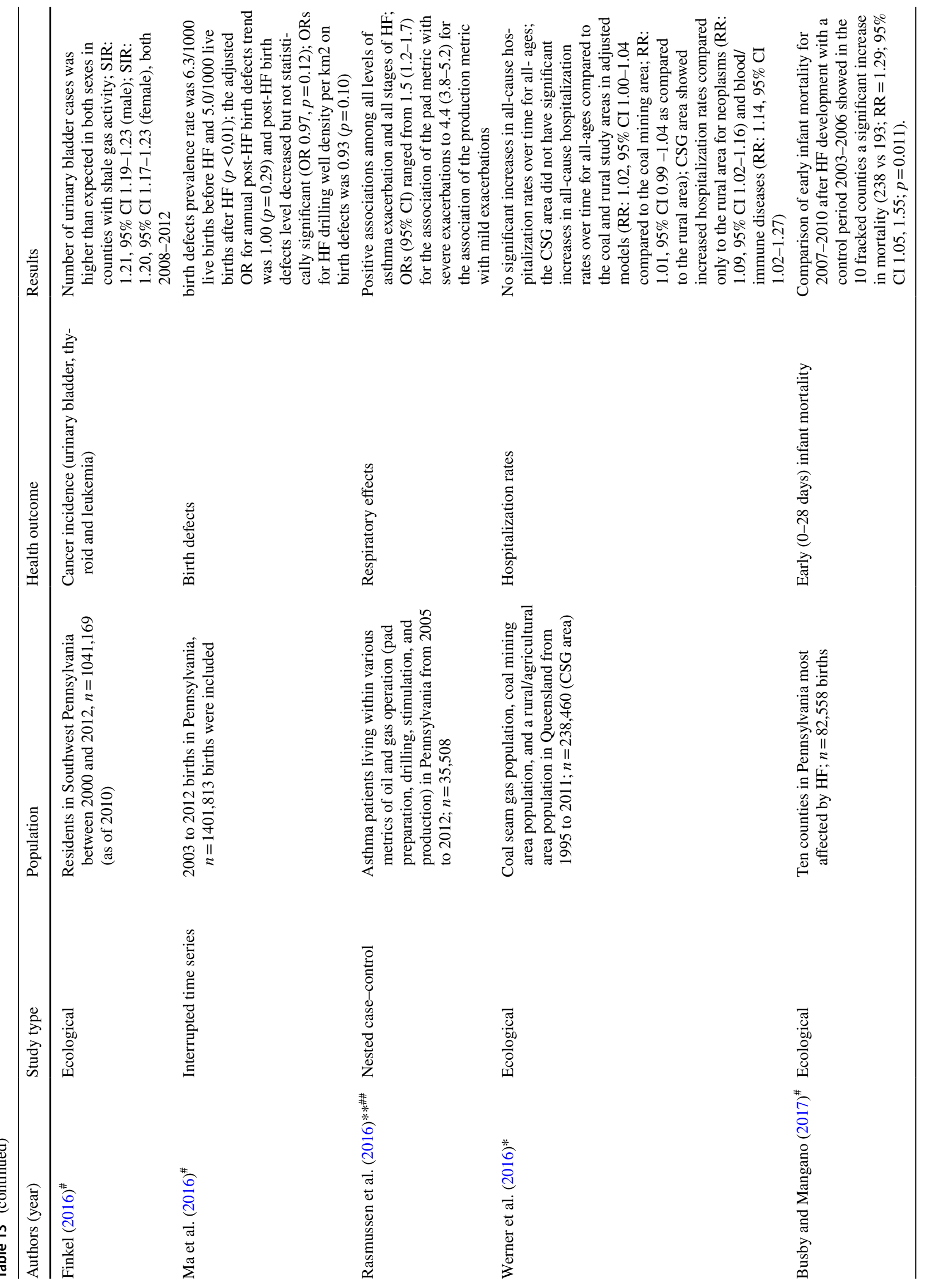




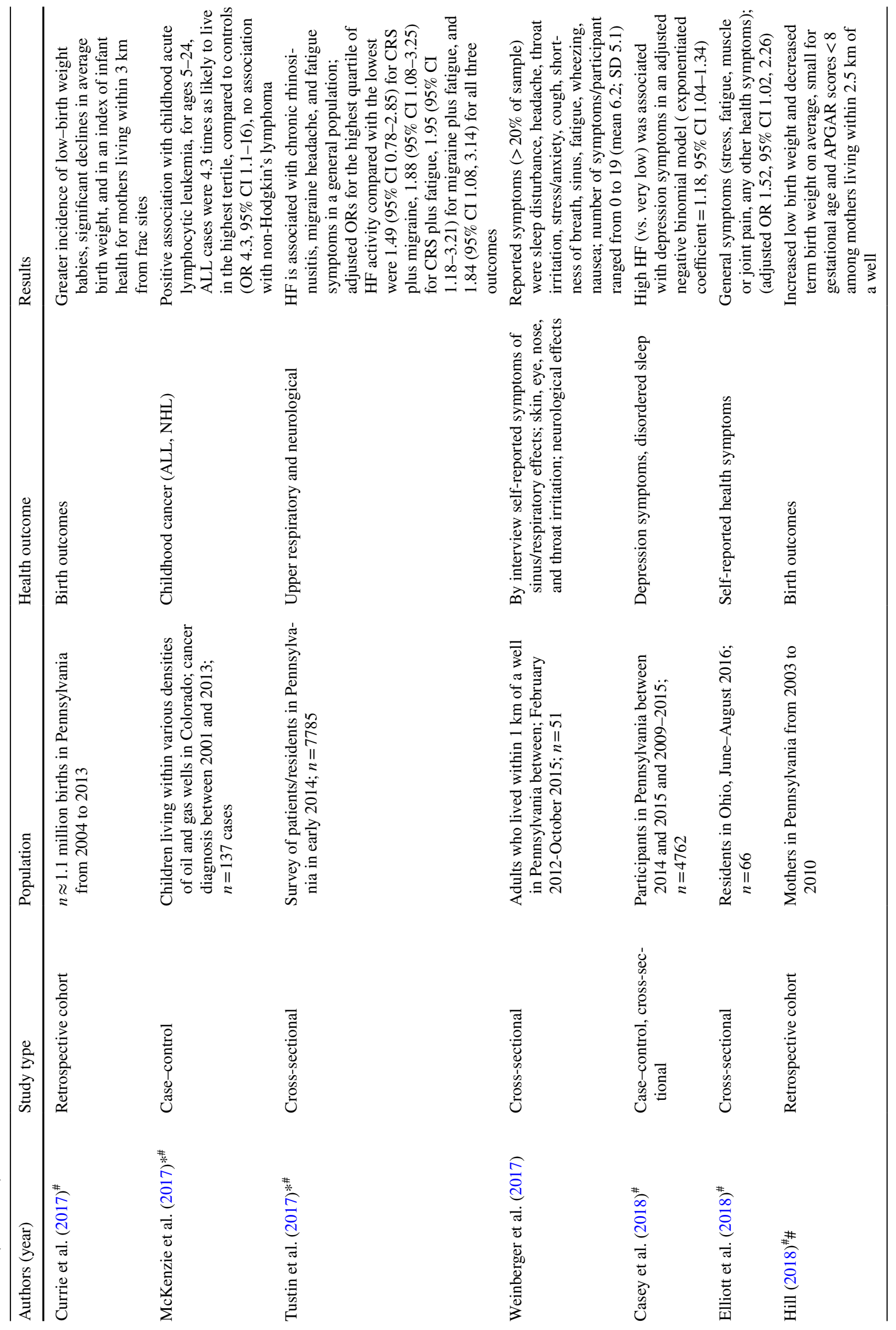




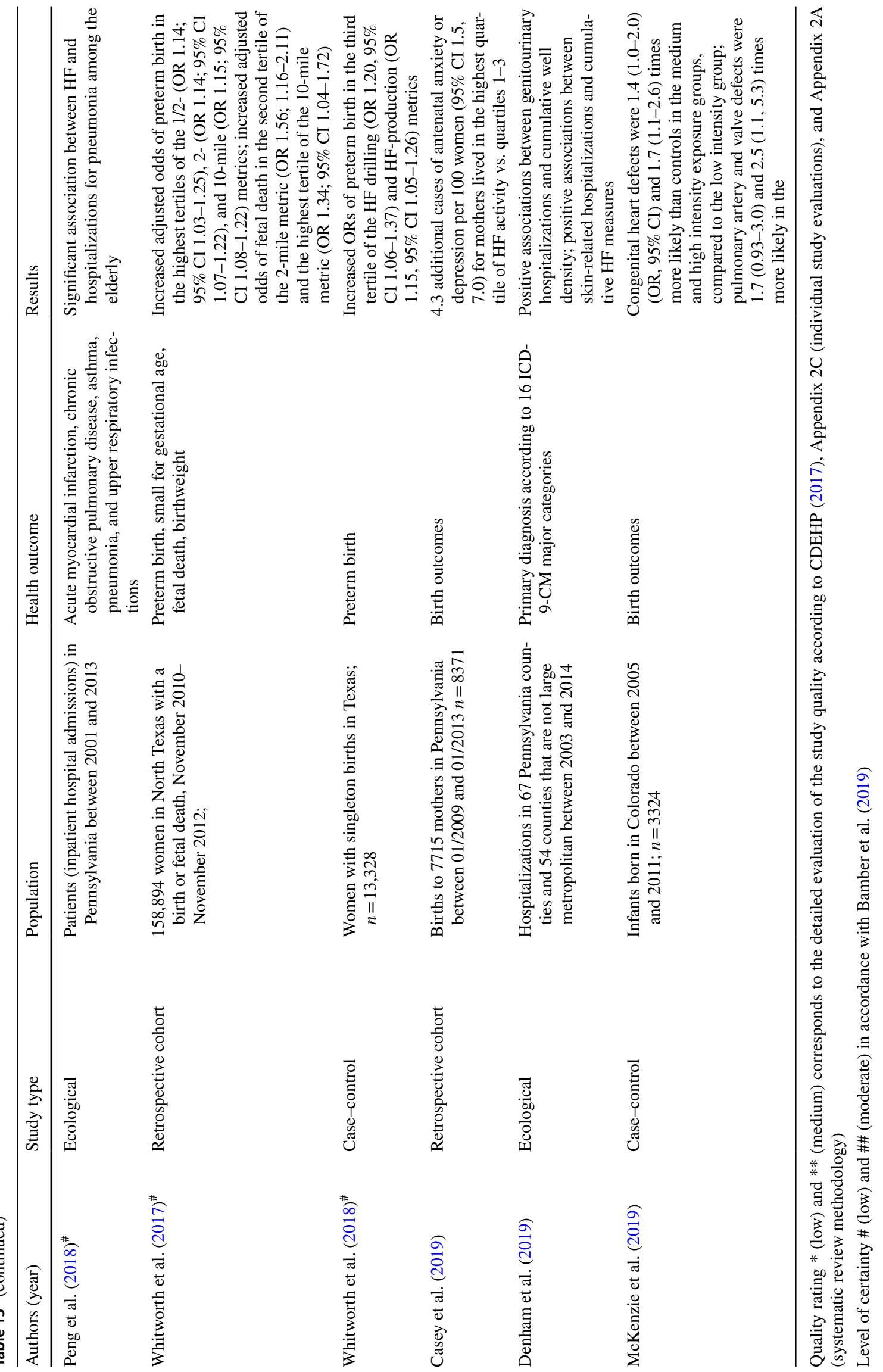


With 16.8 expected cases, this did not represent a statistically significant result (SIR: 0.89; 95\% CI 0.50-1.47).

In a follow-up study, 6978 inhabitants of the joint community Bothel were invited to be interviewed concerning their own hematological diseases and hematological diseases of relatives based on an environmental-medical questionnaire. The response rates ranged between 69.3 and $61.2 \%$ in the individual communes. In total, 37 validated incident cases in men occurred between 1997 and 2015. During statistical evaluation, an indication was obtained for an increased cancer incidence for individuals employed in the wood-processing industry. Case-control analyses were performed for (a) all 37 hematological cancer cases (between 1997 and 2015), (b) the 26 cases with non-Hodgkin lymphoma (1995-2015) and (c) only the 19 cases of non-Hodgkin lymphoma and multiple myeloma (MM) diagnosed between 2007 and 2015. Using these comparisons, a possible association was studied between hematological cancer cases in men and the distance of the place of residence to the following potential sources of emission: (a) gas production site, (b) sludge pits, (c) woodprocessing companies, (d) metal-processing companies, (e) petrol stations, (f) agricultural trading stations, (g) garden centers, (h) former railway lines due to the use of pesticides. These analyses resulted only in an indication of a possible association between the distance of residence to drilling fluid pits and hematological cancer cases in men.

The observation of increased hematological cancer cases in the first study of the joint community Bothel (EKN 2014) triggered an extended study including seven communities east and west of the joint community Bothel and the city of Rotenburg located northwest of Bothel (EKN 2015). The communities were grouped into three regions, A-C, and the risk of hematological cancer incidence between 2003 and 2012 was analyzed (EKN 2015). A statistically significantly increased cancer incidence for leukemia and MM was obtained for the city of Rotenburg (region B) with 72 observed, compared to 54.8 expected cancer cases (SIR: $1.31 ; 95 \%$ CI 1.03-1.66) only for men. By contrast, no statistically significant difference was obtained for women, with 53 observed and 48.3 expected cancer cases (SIR: 1.10; $95 \%$ CI 0.82-1.43). The strongest increase for men was obtained for MM. No significant increase in cancer incidence was observed for regions A and C (EKN 2015). It is striking that a similar pattern of increased cancer incidence was observed for the city of Rotenburg and the joint community of Bothel, but not for the other regions.

A further study was performed in the joint community Steimbke in Lower Saxony (EKN 2016), triggered by evidence of a possibly increased incidence of childhood leukemia in one of the local communities (Rodewald). Of the 46 hematological cancer cases registered between 2005 and 2013 in the joint community Steimbke, 19 occurred directly in the community Rodewald and further 24 cases in other communities of this region. However, for three of the 46 cases, no information was available on the exact place of residence. Summarizing all cases of males and females, 46 hematological cancer cases were observed, compared to 36.2 expected (SIR: 1.27 ; 95\% CI 0.93-1.69). Considering the community Rodewald alone, 20 incident cases were observed, compared to 12.7 expected (SIR: $1.27 ; 95 \%$ CI 0.93-1.69). Both SIR were statistically not significant; however, statistical significance would have been reached if two of the three cases for whom no information on the place of residence was available, would have been assigned to the community of Rodewald.

In parallel, the German Childhood Cancer Registry performed an evaluation of incidental hematological cancer cases in children aged $<15$ years in the region's joint community of Steimbke and the community Rodewald (EKN 2016). In the observation period between 1987 and 2014, six cases of childhood leukemia were observed, compared to 1.7 expected (SIR: 3.6; 95\% CI 1.3-7.8). The place of residence of four cases was Rodewald, where only 0.6 cases were expected (SIR: 6.8; 95\% CI 1.9-17.4). Therefore, a statistically significantly increased incidence of childhood leukemia in the joint community Steimbke and the community Rodewald was confirmed. Moreover, the temporal clustering was evident because, between 2004 and 2007, three incident cases were already observed in Rodewald and two further in Steimbke. A structured interview by means of a medical questionnaire of the six cancer patients revealed no evidence of relevant commonalities (Nienburg 2017). The toxicological analysis of environmental pollution of the former production site, the extent of expected additional and total emissions, and the increased cases of childhood leukemia lead to a plausible scenario of exposure and adverse health effects. It should be considered that regional clusters of childhood leukemia and lymphoma represent a global, not yet fully understood, phenomenon (Grosche et al. 2017).

The above-described statistically significant associations led to the question of whether proximity of the place of residence to oil or gas production sites or to sludge pits is generally associated with an increased incidence of hematological cancer (ICD 10, C81-C96) in Lower Saxony. To answer this question, a comprehensive case-control study was performed (Forster et al. 2018). For this purpose, 3978 hematological cancer cases registered in the Epidemiological Cancer Register of Lower Saxony were compared to 15,912 controls (no cancer) that were randomly chosen from the register of residents. As a measure of exposure, the $1 \mathrm{~km}$ radius of the place of residence of cases and controls to (a) oil or gas production sites $(n=637)$ and (b) sludge pitches $(n=493)$ were chosen. To analyze a possible association between exposure ( $1 \mathrm{~km}$ radius) and cancer cases, logistic regression models were used which were adjusted for the confounders 'proximity of residence to main roads' and 
'proximity of residence to agricultural areas'. Further confounders were not considered. No significant association was obtained for the two main hypotheses: proximity to production sites and incidence of hematological cancer (OR 0.98; 95\% CI 0.85-1.13), or proximity to sludge pits and incidence of hematological cancer (OR 0.97; 95\% CI 0.81-1.17). There were no differences observed between males and females. Moreover, both exposure measures were also not associated with further cancer entities, such as non-Hodgkin lymphoma, MM or acute myeloid lymphoma. The abovedescribed significant association of an increased incidence of hematological cancer for Rotenburg identified in 2014 was also observed in the comprehensive case-control study; however, no significant association was obtained when the entire region was considered. In conclusion, comprehensive epidemiological studies in Lower Saxony showed several local associations with an increased cancer risk; however, this was not confirmed when all regions with proximity to production sites in Lower Saxony were considered. Therefore, the comprehensive studies did not lead to the establishment of a causal relationship of oil and gas production in Lower Saxony and increased cancer risk.

\section{Human biomonitoring studies (HBM)}

Only a few studies analyzed internal exposure to HF-related chemicals. Caron-Beaudoin et al. (2018) evaluated gestational exposure to benzene and toluene as known developmental toxicants in the Peace River Valley, Northeastern British Columbia (Canada). Metabolites of benzene [ $S$-phenylmercapturic acid (S-PMA) and trans,trans-muconic acid $(\mathrm{t}, \mathrm{t}-\mathrm{MA})]$, and toluene [S-benzylmercapturic acid (S-BMA)] were measured in pooled urine samples from 29 pregnant women who collected $12 \mathrm{~mL}$ urine samples over five consecutive days. The median sampling time was 9:00 PM, and ranged from 2:00 PM (10th percentile) to 11:00 PM (95th percentile). The median S-PMA level $(0.18 \mu \mathrm{g} / \mathrm{g}$ creatinine $)$ in this study was similar to that in the general Canadian population. However, the median t,t-MA level $(180 \mu \mathrm{g} / \mathrm{g}$ creatinine) was approximately 3.5 times higher. Participants that reported exposure to cigarette smoke had median urinary S-PMA, t,t-MA and S-BMA levels of 0.21, 202 and $6.88 \mu \mathrm{g} / \mathrm{g}$ creatinine, respectively. Participants with exposure from the workplace $(n=6)$ such as mining industry, natural gas, construction, forestry, pipeline maintenance or at hydroelectric dams had median urinary S-PMA, t,t-MA and S-BMA levels of $0.23,347$ and $4.31 \mu \mathrm{g} / \mathrm{g}$ creatinine, respectively. The median urinary level of S-BMA in the participants correlated well with the median of $7.2 \mu \mathrm{g} / \mathrm{g}$ creatinine from female Americans that participated in the National Health and Nutrition Examination Survey (NHANES). The observed t,t-MA levels may be due to sorbic acid, a food preservative partially metabolized into t,t-MA. Further limitations of the study are the small numbers of participants and not using 24-h urine samples.

The confirmed cluster of hematological malignancies in a residential population adjacent to natural gas fields (NGFs) in Lower Saxony (Germany) triggered the conduct an HBM study to determine the current internal and external exposure of residents near NGFs to benzene (Göen et al. 2019, 2020). In total, 110 residents (73 non-smokers and 37 smokers) were recruited from the joint community, with NGFs (study group) and 84 residents (non-smokers only) of the same county without NGFs (controls, COs). Probands collected 24-h urine samples over two consecutive workdays and two non-workdays within 14 days from 12/07/18 to 30/07/18 (SG), and from $29 / 10 / 18$ to $16 / 11 / 18$ (study group and controls). S-PMA excretion in the study group was higher for smokers (median $2.33 \mu \mathrm{g} / \mathrm{g}$ creatinine, range $0.10-25.2 \mu \mathrm{g} / \mathrm{g}$ creatinine, $n=37$ ) than for non-smokers (median $0.11 \mu \mathrm{g} / \mathrm{g}$ creatinine, range $0.05-1.17 \mu \mathrm{g} / \mathrm{g}$ creatinine, $n=65$ ) during sampling in the fall. However, there was no difference between non-smokers of the potentially exposed study group and controls (median $0.12 \mu \mathrm{g} / \mathrm{g}$ creatinine, range $0.03-0.72 / \mathrm{g}$ creatinine, $n=78$ ). S-PMA levels in the study group were higher in fall when compared to sampling in summer [nonsmokers: median $0.11 \mu \mathrm{g} / \mathrm{g}$ creatinine $(n=65)$ vs. $0.05 \mu \mathrm{g} / \mathrm{g}$ creatinine $(n=66)$; smokers: median $2.33 \mu \mathrm{g} / \mathrm{g}$ creatinine vs. $1.51 \mu \mathrm{g} / \mathrm{g}$ creatinine, both $n=37]$. Median benzene air levels were $1.03,1.09$, and $0.50 \mu \mathrm{g} / \mathrm{m}^{3}$ for personalized, indoor air, and ambient air samples for non-smokers in fall.

In response to citizens' concerns living in and near the town of DISH (Barnett Shale), the Texas Department of State Health Services (TxDSHS) conducted an HBM study collecting blood and urine samples (first morning void) from 28 people. Blood samples were analyzed for a wide range of VOCs. Although several VOCs were detected in some of the blood samples (1,2-dichloroethane; tetrachloroethene; bromoform; benzene; chloroform; dibromochloromethane; 1,4-dichlorobenzene; ethylbenzene; $o$-xylene; styrene; trichloroethene; 1,1,1-trichloroethane; toluene, and $m-/ p$ xylene), the pattern of VOC values was not consistent with a community-wide exposure to airborne contaminants, such as those that might be associated with natural gas drilling operations. Some individuals showed higher blood levels of bromoform $(n=3)$, chloroform $(n=10)$, and dibromochloromethane $(n=4)$ than $95 \%$ of the U.S. population. Other compounds that were found in a few individuals at levels higher than $95 \%$ of the general U.S. population included 1,2-dichloroethane, tetrachloroethene, 1,4-dichlorobenzene, trichloroethene, and 1,1,1-trichloroethane. Benzene levels in blood ranged from < LOD-0.027 (non-smokers) and $0.045-1.45$ (smokers) $\mu \mathrm{g} / \mathrm{L}$ and were detected in six individuals. Toluene, $m-/ p$-xylene, and ethylbenzene were measured ranging from $<\mathrm{LOD}-3.25 \mu \mathrm{g} / \mathrm{L}(n=18),<\mathrm{LOD}-$ $1.32(n=15)$, and $<$ LOD-0.437 $\mu \mathrm{g} / \mathrm{L}(n=8)$, respectively. 
S-PMA ranged from $<$ LOD- $0.40 \mu \mathrm{g} / \mathrm{g}$ creatinine (nonsmokers) and $<$ LOD $-2.79 \mu \mathrm{g} / \mathrm{g}$ creatinine (smokers). The DISH median values of benzene, toluene, and $m-/ p$-xylene were not significantly different than the reference median from NHANES. Considering the short half-life of excretion of the investigated VOCs, the utilization of first morning void samples is critical.

\section{Summary}

So far, the scientific investigation of possible health risks mediated by hydraulic fracturing operations has led to inconsistent results. The most critical part of risk assessment in this context is the exposure assessment which is hampered by the unavailability of data from qualified baseline monitoring before the start of frac operations. Hence, when assessing the HF impact on the environment and human health it is often difficult or practically impossible to estimate the proportion of HF which is contributing to the existing exposure. With regard to the origin of the emissions to be considered from $\mathrm{HF}$ and non-HF processes, differentiation must be made using suitable and specific target substances. They require adapted monitoring strategies and procedures for ground and surface waters as well as ambient air. Of all the sub-processes of HF operations, the fate and behavior of the production water and flow-back in the environment currently seems to be the greatest challenge. The complex pollutant inventories in the case of flow-back or production water are only approximately known. They are of particular importance if improper disposal of the production water can directly contaminate drinking water resources. The sustainable disposal of production water and flow-back or their reuse remains a challenge.

The use of realistic exposure scenarios, which are based on a strictly usage-based view of the subject of protection, is fundamental to the assessment of health risks from HF operations. Looking only/exclusively at the intrinsic toxicity of the frac chemicals cannot be conducive. Available epidemiological studies have shown significant associations between the emissions from HF processes and the observed health effects, but even large studies have not been able to prove a clear causality. Since in epidemiological studies human exposure is largely described using various distance measures as a surrogate, the challenge for future studies will be to use measured concentrations of pollutants. The fact that the exact composition of frac fluids and production water is partly not known (the recipes have only recently been published in relevant registers) can now be countered by analyzing the pollution in the subject of protection with an advanced range of chemical analytical methods. The use of frac chemicals with CMR properties remains problematic if it is still approved by governmental regulations. That in the past the toxicological database of used frac chemicals has been partially incomplete is a critical point in human risk assessment. In this case, for a sound characterization of the hazard of the relevant frac chemicals and human health risks, toxicological alternatives such as the precautionary-oriented TTC or HRIV approach should be used. The continuing utilization of the hydraulic fracturing technology requires compulsorily a well-founded contribution from toxicology with regard to the identification of possible hazard potentials of the relevant chemicals, the exposure characterization based on measured substance's concentrations, and to the evaluation of health risks in relation to the general population.

Acknowledgements Open Access funding provided by Projekt DEAL.

\section{Compliance with ethical standards}

Conflict of interest This study has been conducted by the Advisory Committee of the German Society of Toxicology (AC). The AC is elected by the members of the German Society of Toxicology and consists of representatives from academia, industry and administration to guarantee a broad range of toxicological competence. The AC presents and justifies its activities to the members of the German Society of Toxicology, for example at the yearly plenary meeting. The German Society of Toxicology is the largest scientific toxicological organization in Europe, with more than 1300 members. In the past 10 years, the Advisory Committee has already published review articles about inorganic arsenic in food (Gundert-Remy et al. 2015), nanotoxicology (Gebel et al. 2014), bisphenol A (Hengstler et al. 2011), alternative methods to animal experiments (Lilienblum et al. 2008) and REACH (Hengstler et al. 2006). Commentaries to hydraulic fracturing have not yet been published by the AC.

Open Access This article is licensed under a Creative Commons Attribution 4.0 International License, which permits use, sharing, adaptation, distribution and reproduction in any medium or format, as long as you give appropriate credit to the original author(s) and the source, provide a link to the Creative Commons licence, and indicate if changes were made. The images or other third party material in this article are included in the article's Creative Commons licence, unless indicated otherwise in a credit line to the material. If material is not included in the article's Creative Commons licence and your intended use is not permitted by statutory regulation or exceeds the permitted use, you will need to obtain permission directly from the copyright holder. To view a copy of this licence, visit http://creativecommons.org/licenses/by/4.0/.

\section{References}

13th Adaptation to Technical Progress (ATP) Commission Regulation (EU) 2018/1480 of 4 October 2018 amending, for the purposes of its adaptation to technical and scientific progress, Regulation (EC) No 1272/2008 of the European Parliament and of the Council on classification, labelling and packaging of substances and mixtures and correcting Commission Regulation (EU) 2017/776 (Text with EEA relevance.). https://eur-lex.europa.eu/legal -content/EN/TXT/PDF/?uri=CELEX:32018R1480\&from=EN. Accessed 13 Jan 2020

40 U.S. Code of Federal Regulations, CFR, 125.3, Technology-based treatment requirements in permits, subpart C. https://www.law. cornell.edu/cfr/text/40/125.3 
40 U.S. Code of Federal Regulations, CFR Part 435-OIL AND GAS EXTRACTION POINT SOURCE CATEGORY. https://www. law.cornell.edu/cfr/text/40/part-435

Adgate JL, Goldstein BD, McKenzie LM (2014) Potential public health hazards, exposures and health effects from unconventional natural gas development. Environ Sci Technol 48(15):8307-8320. https://doi.org/10.1021/es404621d

Ahmadi M, John K (2015) Statistical evaluation of the impact of shale gas activities on ozone pollution in North Texas. Sci Total Environ 536:457-467. https://doi.org/10.1016/j.scitotenv.2015.06.114

Ahmed U, Meehan DN (2016) Unconventional oil and gas resources: exploitation and development. CRC Press, Boca Raton

Akob DM, Cozzarelli IM, Dunlap DS et al (2015) Organic and inorganic composition and microbiology of produced waters from Pennsylvania shale gas wells. Appl Geochem 60:116-125. https ://doi.org/10.1016/j.apgeochem.2015.04.011

Alawattegama SK, Kondratyuk T, Krynock R et al (2015) Well water contamination in a rural community in southwestern Pennsylvania near unconventional shale gas extraction. J Environ Sci Health A Tox Hazard Subst Environ Eng 50(5):516-528. https ://doi.org/10.1080/10934529.2015.992684

Allen DT (2016) Emissions from oil and gas operations in the United States and their air quality implications. J Air Waste Manag Assoc 66(6):549-575. https://doi.org/10.1080/10962 247.2016.1171263

ATSDR (Agency for Toxic Substances and Disease Registry (ATSDR) (2019) Minimal Risk Levels (MRLs). https://www.atsdr.cdc.gov/ mrls/index.asp. Accessed 13 Jan 2020

Balise VD, Meng CX, Cornelius-Green JN et al (2016) Systematic review of the association between oil and natural gas extraction processes and human reproduction. Fertil Steril 106(4):795-819. https://doi.org/10.1016/j.fertnstert.2016.07.1099

Bamber AM, Hasanali SH, Nair AS et al (2019) A systematic review of the epidemiologic literature assessing health outcomes in populations living near oil and natural gas operations: study quality and future recommendations. Int J Environ Res Public Health 16(12):E2123. https://doi.org/10.3390/ijerph16122123

Barati R, Liang JT (2014) A review of fracturing fluid systems used for hydraulic fracturing of oil and gas wells. J Appl Polym Sci 131(16):40735. https://doi.org/10.1002/app.40735

Barbot E, Vidic NS, Gregory KB, Vidic RD (2013) Spatial and temporal correlation of water quality parameters of produced waters from Devonian-age shale following hydraulic fracturing. Environ Sci Technol 47(6):2562-2569. https://doi.org/10.1021/es304 $638 \mathrm{~h}$

Bergmann A, Weber FA, Meiners HG, Müller F (2014) Potential waterrelated environmental risks of hydraulic fracturing employed in exploration and exploitation of unconventional natural gas reservoirs in Germany. Environ Sci Europe 26:10

BGR (Bundesanstalt für Geowissenschaften und Rohstoffe) (Hrsg.) (2016) Schieferöl und Schiefergas in Deutschland—Potenziale und Umweltaspekte. Januar 2016

Blondes MS, Gans KD, Thordsen JJ et al (2014) U.S. geological survey national produced waters geochemical database v2.1 (Provisional). Publisher: U.S. Geological Survey (USGS); HERO ID 2447516. https://semanticommunity.info/@api/deki/files/35790 /USGS_Produced_Waters_Database_v2.1_Documentation.pdf. Accessed 13 Jan 2020

BMU (Bundesministerium für Umwelt, Naturschutz, Bau und Reaktorsicherheit) (2017). https://www.bmu.de/. Accessed 13 Jan 2020

Boyer EW, Swistock BR, Clark J et al (2012) The impact of Marcellus gas drilling on rural drinking water supplies. Center for Rural Pennsylvania, March 2012. http://www.rural.palegislature.us/ documents/reports/Marcellus_and_drinking_water_2012.pdf. Accessed 13 Jan 2020
Brown D, Weinberger B, Lewis C, Bonaparte H (2014) Understanding exposure from natural gas drilling puts current air standards to the test. Rev Environ Health 29(4):277-292. https://doi. org/10.1515/reveh-2014-0002

Bunch AG, Perry CS, Abraham L et al (2014) Evaluation of impact of shale gas operations in the Barnett Shale region on volatile organic compounds in air and potential human health risks. Sci Total Environ 468-469:832-842. https://doi.org/10.1016/j.scito tenv.2013.08.080

Busby C, Mangano J (2017) There's a world going on undergroundinfant mortality and fracking in Pennsylvania. J Environ Prot 8(4):381-393. https://doi.org/10.4236/jep.2017.84028

BVEG (Bundesverband Erdgas, Erdöl und Geoenergie e. V.) (2017). http://www.bveg.de/Themen/Technik-Standards/Fracking/InfoPlattform-zu-Fracking. Accessed 13 Jan 2020

Caron-Beaudoin É, Valter N, Chevrier J et al (2018) Gestational exposure to volatile organic compounds (VOCs) in Northeastern British Columbia, Canada: a pilot study. Environ Int 110:131-138. https://doi.org/10.1016/j.envint.2017.10.022

Casey JA, Savitz DA, Rasmussen SG et al (2016) Unconventional natural gas development and birth outcomes in Pennsylvania, USA. Epidemiology 27(2):163-172. https://doi.org/10.1097/ EDE.0000000000000387

Casey JA, Wilcox HC, Hirsch AG et al (2018) Associations of unconventional natural gas development with depression symptoms and disordered sleep in Pennsylvania. Sci Rep 8(11):11375. https ://doi.org/10.1038/s41598-018-29747-2

Casey JA, Goin DE, Rudolph KE et al (2019) Unconventional natural gas development and adverse birth outcomes in Pennsylvania: the potential mediating role of antenatal anxiety and depression. Environ Res 177:108598. https://doi.org/10.1016/j.envre s.2019.108598

CDEHP (Colorado Department of Public Health and Environment) (2017) Assessment of potential public health effects from oil and gas operations in Colorado. https://drive.google.com/file/ d/0B0tmPQ67k3NVVFc1TFg 1eDhMMjQ/view. Accessed 13 Jan 2020

Cheremisinoff NP, Davletshin A (2015) Hydraulic fracturing operations: handbook of environmental management practices. Wiley. https://doi.org/10.1002/9781119099987.ch3

COGCC: https://cogcc.state.co.us/Announcements/Hot_Topics/Hydra ulic_Fracturing/Hydra_Frac_topics.html. Accessed 13 Jan 2020

Colborn T, Schultz K, Herrick L, Kwiatkowski C (2014) An exploratory study of air quality near natural gas operations. Hum Ecol Risk Assess 20(1):86-105. https://doi.org/10.1080/10807 039.2012 .749447

COM (2014) Commission Recommendation 2014/70/EU of 22 January 2014 on minimum principles for the exploration and production of hydrocarbons (such as shale gas) using high-volume hydraulic fracturing. https://eur-lex.europa.eu/legal-content/EN/TXT/ HTML/?uri=LEGISSUM:1801_4. Accessed 13 Jan 2020

COM (2016) Commission Implementing Regulation (EU) 2016/131 of 1 February 2016 approving C(M)IT/MIT (3:1) as an existing active substance for use in biocidal products for product-types 2, 4, 6, 11, 12 and 13. https://eur-lex.europa.eu/legal-content/ EN/TXT/PDF/?uri=CELEX:32016R0131\&from=EN. Accessed 13 Jan 2020

COM (2018) 13th Adaptation to Technical Progress (ATP) Commission Regulation (EU) 2018/1480 of 4 October 2018 amending, for the purposes of its adaptation to technical and scientific progress, Regulation (EC) No 1272/2008 of the European Parliament and of the Council on classification, labelling and packaging of substances and mixtures and correcting Commission Regulation (EU) 2017/776. https://eur-lex.europa.eu/legal -content/EN/TXT/PDF/?uri=CELEX:32018R1480\&from=EN. Accessed 13 Jan 2020 
Commission Of The European Communities (2000) Communication from the Commission on the precautionary principle. https:// op.europa.eu/en/publication-detail/-/publication/21676661-a79f4153-b984-aeb28f07c80a/language-en. Accessed 13 Jan 2020

Costa D, Jesus J, Branco D et al (2017) Extensive review of shale gas environmental impacts from scientific literature (2010-2015). Environ Sci Pollut Res Int 24(17):14579-14594. https://doi. org/10.1007/s11356-017-8970-0

Cuadrilla (2017) https://cuadrillaresources.uk/about-fracking/. Accessed 13 Jan 2020

Currie J, Greenstone M, Meckel K (2017) Hydraulic fracturing and infant health: new evidence from Pennsylvania. Sci Adv 3(12):e1603021. https://doi.org/10.1126/sciadv.1603021

Dahm KG, Guerra KL, Xu P, Drewes JE (2011) Composite geochemical database for coalbed methane produced water quality in the Rocky Mountain region. Environ Sci Technol 45(18):7655-7663. https://doi.org/10.1021/es201021n

Dannwolf U, Heckelsmüller A, Steiner N et al (2014) Environmental impacts of hydraulic fracturing related to the exploration and exploitation of unconventional natural gas, in particular of shale gas part 2-groundwater monitoring concept, fracking chemicals registry, disposal of flowback, current state of research on emissions/climate balance, induced seismicity, impacts on the ecosystem, the landscape and biodiversity. Summary. On behalf of the Federal Environment Agency (Germany), Dessau-Roßlau, July 2014. https://www.umweltbundesamt.de/sites/default/files /medien/378/publikationen/texte_53_2014_umweltauswirkun gen_von_fracking_0.pdf. Accessed 13 Jan 2020

Darrah TH, Vengosh A, Jackson RB et al (2014) Noble gases identify the mechanisms of fugitive gas contamination in drinking-water wells overlying the Marcellus and Barnett Shales. Proc Natl Acad Sci USA 111(39):14076-14081. https://doi.org/10.1073/ pnas. 1322107111

Denham A, Willis M, Zavez A, Hill E (2019) Unconventional natural gas development and hospitalizations: evidence from Pennsylvania, United States, 2003-2014. Public Health 168:17-25. https:// doi.org/10.1016/j.puhe.2018.11.020

Dieter HH (2014) Health related guide values for drinking-water since 1993 as guidance to assess presence of new analytes in drinkingwater. Int J Hyg Environ Health 217(2-3):117-132. https://doi. org/10.1016/j.ijheh.2013.05.001

DiGiulio DC, Jackson RB (2016) Impact to underground sources of drinking water and domestic wells from production well stimulation and completion practices in the Pavillion, Wyoming Field. Environ Sci Technol 50(8):4524-4536. https://doi.org/10.1021/ acs.est.5b04970

DIRECTIVE 2008/50/EC of the European Parliament and of the Council of 21 May 2008 on ambient air quality and cleaner air for Europe. https://eur-lex.europa.eu/legal-content/EN/TXT/ $\mathrm{PDF} /$ ?uri=CELEX:32008L0050\& from $=\mathrm{en}$

DOE (U.S. Department of Energy) (2014) Water management strategies for improved coalbed methane production in the Black Warrior Basin. Publisher: U.S. Department of Energy, Tuscaloosa, AL. Final report. https://netl.doe.gov/sites/default/files/2018-02/ fe0000888-final-report.pdf. Accessed 13 Jan 2020

Drollette BD, Hoelzer K, Warner NR et al (2015) Elevated levels of diesel range organic compounds in groundwater near Marcellus gas operations are derived from surface activities. Proc Natl Acad Sci USA 112(43):13184-13189. https://doi.org/10.1073/ pnas. 1511474112

Dyck W, Dunn CE (1986) Helium and methane anomalies in domestic well waters in southwestern Saskatchewan, Canada, and their relationship to other dissolved constituents, oil and gas fields, and tectonic patterns. J Geophys Res Solid Earth 91(B12):1234312353. https://doi.org/10.1029/JB091iB12p12343
Eionet (European Environment Information and Observation Network), Central Data Repository (2020) GHG Inventory EU, Germany, $16 \mathrm{Jan}$ 2020. https://cdr.eionet.europa.eu/de/eu/mmr/art07_inven tory/ghg_inventory/envxh8awg/. Accessed 13 Jan 2020

EKN (Epidemiologisches Krebsregister Niedersachsen) (2014) Auswertung des EKN zur Häufigkeit von Krebsneuerkrankungen in der Samtgemeinde Bothel. September 2014. http://www.krebs register-niedersachsen.de/dateien/aktuellesnews/pdf/EKN_Beric ht_SG\%20Bothel_2014_09_11.pdf. Accessed 13 Jan 2020

EKN (Epidemiologisches Krebsregister Niedersachsen) (2015) Auswertung des EKN zur Häufigkeit von Krebsneuerkrankungen in den Nachbargemeinden der Samtgemeinde Bothel. Juni 2015. http://www.krebsregister-niedersachsen.de/dateien/aktuellesn ews/pdf/Bothel_Nachbargemeinden/EKN_Bericht\%20Nachbarg emeinden\%20SG\%20Bothel_062015.pdf. Accessed 13 Jan 2020

EKN (Epidemiologisches Krebsregister Niedersachsen) (2016) Auswertung des EKN zur Häufigkeit von hämatologischen Krebsneuerkrankungen in der Samtgemeinde Steimbke und der Gemeinde Rodewald. http://www.krebsregister-niedersachsen. de/dateien/aktuellesnews/pdf/EKN_Bericht\%20SG_Steimbke_ Rodewald_201604.pdf. Accessed 13 Jan 2020

Elliott EG, Trinh P, Ma X et al (2017a) Unconventional oil and gas development and risk of childhood leukemia: assessing the evidence. Sci Total Environ 576:138-147. https://doi.org/10.1016/j. scitotenv.2016.10.072

Elliott EG, Ettinger AS, Leaderer BP et al (2017b) A systematic evaluation of chemicals in hydraulic-fracturing fluids and wastewater for reproductive and developmental toxicity. J Expo Sci Environ Epidemiol 27(1):90-99. https://doi.org/10.1038/jes.2015.81

Elliott EG, Ma X, Leaderer BP et al (2018) A community-based evaluation of proximity to unconventional oil and gas wells, drinking water contaminants, and health symptoms in Ohio. Environ Res 167:550-557. https://doi.org/10.1016/j.envres.2018.08.022

Elsner M, Hoelzer K (2016) Quantitative survey and structural classification of hydraulic fracturing chemicals reported in unconventional gas production. Environ Sci Technol 50(7):290-3314. https://doi.org/10.1021/acs.est.5b02818

Elsner M, Schreglmann K, Calmano W et al (2015) Comment on the German draft legislation on hydraulic fracturing: the need for an accurate state of knowledge and for independent scientific research. Environ Sci Technol 49(11):6367-6369. https://doi. org/10.1021/acs.est.5b01921

Esswein EJ, Snawder J, King B et al (2014) Evaluation of some potential chemical exposure risks during flowback operations in unconventional oil and gas extraction: preliminary results. J Occup Environ Hyg 11(10):D174-D184. https://doi. org/10.1080/15459624.2014.933960

Ethridge S, Bredfeldt T, Sheedy K et al (2015) The Barnett Shale: from problem formulation to risk management. J Unconv Oil Gas Resour 11:95-110. https://doi.org/10.1016/j.juogr 2015.06.001

Ewen C, Borchardt D, Richter S, Hammerbacher R (2012) Risikostudie Fracking-Sicherheit und Umweltverträglichkeit der Fracking-Technologie für die Erdgasgewinnung aus unkonventionellen Quellen (Übersichtsfassung). https://www.ufz.de/expor t/data/2/201587_Abschlussbericht\%20Ex_risikostudiefracking _120518_webprint.pdf. Accessed 13 Jan 2020

Ewers U, Gordalla B, Frimmel F (2013) Fracking - eine Gefahr für das Trinkwasser? Das Gesundheitswesen 75(11):735-741. https ://doi.org/10.1055/s-0033-1355369

ExxonMobile (2017) Fracking Maßnahmen. https://www.erdgas-ausdeutschland.de/Fracking/Fracking/Fracking-Mabnahmen. Accessed 13 Jan 2020

Ferrar KJ, Michanowicz DR, Christen CL et al (2013) Assessment of effluent contaminants from three facilities discharging Marcellus 
Shale wastewater to surface waters in Pennsylvania. Environ Sci Technol 47(7):3472-3481. https://doi.org/10.1021/es301411q

Finkel ML (2016) Shale gas development and cancer incidence in southwest Pennsylvania. Public Health 141:198-206. https:// doi.org/10.1016/j.puhe.2016.09.008

Fontenot BE, Hunt LR, Hildenbrand ZL et al (2013) An evaluation of water quality in private drinking water wells near natural gas extraction sites in the Barnett Shale formation. Environ Sci Technol 47(17):10032-10040. https://doi.org/10.1021/es4011724

Forster F, Herrera R, Radon K (2018) Abschlussbericht zum Forschungsvorhaben „Zusammenhang von hämatologischen Krebserkrankungen und der wohnlichen Nähe zu Schlammgruben(verdachtsflächen) und zu Anlagen der Kohlenwasserstoffförderung in Niedersachsen“. Occupational and Environmental Epidemiology \& NetTeaching Unit, Institute and Outpatient Clinic for Occupational, Social and Environmental Medicine, University Hospital of Munich (LMU), Munich, Germany. http://www.klinikum.uni-muenchen.de/Institut-und-Polik linik-fuer-Arbeits-Sozial-und-Umweltmedizin/download/inhal t/Forschung/AG-Radon/aktuelles/20181130_Abschlussberich t_Abstandsstudie_Vs8.pdf. Accessed 13 Jan 2020

FracFocus3.0 (2020) https://fracfocus.org/. Accessed 13 Jan 2020

Fryzek J, Pastula S, Jiang X, Garabrant DH (2013) Childhood cancer incidence in Pennsylvania counties in relation to living in counties with hydraulic fracturing sites. J Occup Environ Med 55(7):796-801. https://doi.org/10.1097/JOM.0b013e318289ee02

GAA Hildesheim (Staatliches Gewerbeaufsichtsamt), Zentrale Unterstützungsstelle Luftreinhaltung, Lärm und Gefahrstoffe-ZUS LLG (2019) Luftqualitätsüberwachung in Niedersachsen, Jahresbericht 2018. https://www.umwelt.niedersachsen.de/startseite /themen/luftqualitat/lufthygienische_uberwachung_niedersach sen/berichte/jahresberichte/bewertung-der-luftqualitaet-20189127.html. Accessed 13 Jan 2020

Gagnon GA, Krkosek W, Anderson L et al (2016) Impacts of hydraulic fracturing on water quality: a review of literature, regulatory frameworks and an analysis of information gaps. Environ Rev 24(2):122-131. https://doi.org/10.1139/er-2015-0043

Gandossi L, von Estorff U (2015) An overview of hydraulic fracturing and other formation stimulation technologies for shale gas production-update 2015. EUR 26347. https://doi. org/10.2790/379646. https://publications.jrc.ec.europa.eu/repos itory/bitstream/JRC98582/an\%20overview\%20of\%20hydrauli c\%20fracturing\%20and\%20other\%20stimulation\%20technolo gies\%20-\%20update\%202015.pdf. Accessed 13 Jan 2020

Gebel T, Foth H, Damm G et al (2014) Manufactured nanomaterials: categorization and approaches to hazard assessment. Arch Toxicol 88(12):2191-2211. https://doi.org/10.1007/s0020 4-014-1383-7

Gilman JB, Lerner BM, Kuster WC, de Gouw JA (2013) Source signature of volatile organic compounds from oil and natural gas operations in northeastern Colorado. Environ Sci Technol 47(3):1297-1305. https://doi.org/10.1021/es304119a

Göen T, Zethner Ke, Zethner Kr (2019) Human-Biomonitoring (HBM) in der Allgemeinbevölkerung in der Nachbarschaft von Anlagen der Kohlenwasserstoff-Förderung in Niedersachsen. Final report. https://www.ms.niedersachsen.de/download/149537/Abschlussb ericht.pdf. Accessed 13 Jan 2020

Göen Th, Zethner K, Zethner K, Wollin K-M (2020) Human biomonitoring in the resident population in the vicinity of natural gas production facilities in Lower Saxony (Germany). NaunynSchmiedeberg's Arch Pharmacol 393(Suppl 1):S82. https://doi. org/10.1007/s00210-020-01828-y

Goldstein BD, Brooks BW, Cohen SD et al (2014) The role of toxicological science in meeting the challenges and opportunities of hydraulic fracturing. Toxicol Sci 139(2):271-283. https://doi. org/10.1093/toxsci/kfu061
Gordalla BC, Ewers U, Frimmel FH (2013) Hydraulic fracturing: a toxicological threat for groundwater and drinking-water? Environ Earth Sci 70(8):3875-3893. https://doi.org/10.1007/s1266 5-013-2672-9

Gottardo S, Amenta V, Mech A, Sokull-Klüttgen B (2013) Assessment of the use of substances in hydraulic fracturing of shale gas reservoirs under REACH. European Commission, Joint Research Centre, Institute for Health and Consumer Protection, Report EUR 26069 EN, September 2013. https://doi.org/10.2788/86037. https://publications.jrc.ec.europa.eu/repository/bitstream/JRC83 512/req_jrc83512_assessment_use_substances_hydraulic_fract uring_shale_gas_reach.pdf. Accessed 13 Jan 2020

Gottardo S, Mech A, Gavriel M, Gaillard C, Sokull-Klüttgen B (2016). Use of nanomaterials in fluids, proppants, and downhole tools for hydraulic fracturing of unconventional hydrocarbon reservoirs. EUR 28221 EN. https://doi.org/10.2788/65091. https:// publications.jrc.ec.europa.eu/repository/bitstream/JRC103851/ jrc103851_report_nanomaterials-fracturing-final-20161129.pdf. Accessed 13 Jan 2020

Groat CG, Grimshaw TW (2012) Fact-based regulation for environmental protection in shale gas development. The Energy Institute, University of Texas at Austin, Austin, TX 78712. https://www. velaw.com/UploadedFiles/VEsite/Resources/ei_shale_gas_reg summary1202[1].pdf. Accessed 14 Jan 2020

Grosche B, Kaatsch P, Heinzow B, Wichmann HE (2017) The Krümmel (Germany) Childhood Leukaemia Cluster: a review and update. J Radiol Prot 37(4):R43-R58. https://doi.org/10.1088/1361-6498/ aa8ce9

Gross SA, Avens HJ, Banducci AM et al (2013) Analysis of BTEX groundwater concentrations from surface spills associated with hydraulic fracturing operations. J Air Waste Manag Assoc 63(4):424-432

Gundert-Remy U, Damm G, Foth H et al (2015) High exposure to inorganic arsenic by food: the need for risk reduction. Arch Toxicol 89(12):2219-2227. https://doi.org/10.1007/s00204-015-1627-1

Gupta DVS, Hlidek BT (2009) Frac fluid recycling and water conservation: a case history. Book Chapter, 2009 Hydraulic fracturing technology conference. Society of Petroleum Engineers, Woodlands, Texas. https://doi.org/10.2118/119478-ms. http://www. onepetro.org/mslib/app/Preview.do?paperNumber=SPE-11947 8-MS\&societyCode=SPE. Accessed 14 Jan 2020

Gupta DVS, Valkó P (2007) Fracturing fluids and formation damage. In: Economides MJ, Martin T (eds) Modern fracturing: enhancing natural gas production. Energy Tribune Publishing Inc., Houston, pp 227-279

Haley M, McCawley M, Epstein AC et al (2016) Adequacy of current state setbacks for directional high-volume hydraulic fracturing in the Marcellus, Barnett, and Niobrara Shale Plays. Environ Health Perspect 124(9):1323-1333. https://doi.org/10.1289/ ehp. 1510547

Halliburton (2017) Fracturing fluid systems. https://www.halliburto n.com/content/dam/ps/public/pe/contents/Data_Sheets/web/H/ H05667.pdf. Accessed 14 Jan 2020

Haluszczak LO, Rose AW, Kump LR (2013) Geochemical evaluation of flowback brine from Marcellus gas wells in Pennsylvania, USA. Appl Geochem 28:55-61. https://doi.org/10.1016/j.apgeo chem.2012.10.002

Hayes T (2009) Sampling and analysis of water streams associated with the development of Marcellus Shale gas. Final Report. Marcellus Shale Coalition, Des Plaines, IL. http://www.shalenetwork.org/ content/sampling-and-analysis-water-streams-associated-devel opment-marcellus-shale-gas-source-id-10. Accessed 14 Jan 2020

Hayes T, Severin B (2012) Characterization of flowback water from the Marcellus and the Barnett shale regions. Barnett and Appalachian shale water management and reuse technologies. Technical Report, Report Number 08122-05.09; Contract 08122-05 
Hays J, Shonkoff SBC (2016) Toward an understanding of the environmental and public health impacts of unconventional natural gas development: a categorical assessment of the peer-reviewed scientific literature, 2009-2015. PLoS One 11(4):e015416. https ://doi.org/10.1371/journal.pone.0154164

Hengstler JG, Foth H, Kahl R et al (2006) The REACH concept and its impact on toxicological sciences. Toxicology 220(2-3):232-239

Hengstler JG, Foth H, Gebel T et al (2011) Critical evaluation of key evidence on the human health hazards of exposure to bisphenol A. Crit Rev Toxicol 41(4):263-291. https://doi. org/10.3109/10408444.2011.558487

Hill EL (2013) Shale gas development and infant health: evidence from Pennsylvania. Unpublished. The Charles H. Dyson School of Applied Economics and Management, Cornell University, Ithaca, New York. http://citeseerx.ist.psu.edu/viewdoc/download?doi= 10.1.1.664.3770\&rep=rep1\&type $=$ pdf. Accessed 14 Jan 2020

Hill EL (2018) Shale gas development and infant health: evidence from Pennsylvania. J Health Econ 61:134-150. https://doi. org/10.1016/j.jhealeco.2018.07.004

Hill E, Ma L (2017) Shale gas development and drinking water quality. Am Econ Rev 107(5):522-525

Hoelzer K, Sumner AJ, Karatum O et al (2016) Indications of transformation products from hydraulic fracturing additives in shale-gas wastewater. Environ Sci Technol 50(15):8036-8048. https://doi. org/10.1021/acs.est.6b00430

IOGP (International Association of Oil \& Gas Producers) (2017) NGS facts

Jackson RB, Vengosh A, Darrah TH et al (2013) Increased stray gas abundance in a subset of drinking water wells near Marcellus shale gas extraction. Proc Natl Acad Sci USA 110(28):11250 11255. https://doi.org/10.1073/pnas.1221635110

Jemielita T, Gerton GL, Neidell M et al (2015) Unconventional gas and oil drilling is associated with increased hospital utilization rates. PLoS One 10(7):e0131093. https://doi.org/10.1371/journ al.pone. 0131093

Jiang M, Hendrickson CT, VanBriesen JM (2014) Life cycle water consumption and wastewater generation impacts of a Marcellus shale gas well. Environ Sci Technol 48(3):1911-1920. https:// doi.org/10.1021/es4047654

Kahrilas GA, Blotevogel J, Stewart PS, Borch T (2015) Biocides in hydraulic fracturing fluids: a critical review of their usage, mobility, degradation, and toxicity. Environ Sci Technol 49(1):16-32. https://doi.org/10.1021/es503724k

Kassner H (2016) Schiefergaspotential und Weiterentwicklung FrackFluide. Fachausschuss „Chemikalien in Hydrofracking zur Erdgasgewinnung"im Hauptausschuss III der Wasserchemischen Gesellschaft, Fachgespräch „Fracking-Chemikalien“, Frankfurt/ Main, 13.01.2016. http://www.energie-und-chemie.de/fileadmin/ downloads/Service und Informationen/Presse OEffentlichkeit sarbeit/Sonstige/Frac-Fluide_Schiefergas_HK_13_1_2016_ Frankfurt.pdf. Accessed 14 Jan 2020

Kassotis CD, Tillitt DE, Davis JW et al (2014) Estrogen and androgen receptor activities of hydraulic fracturing chemicals and surface and ground water in a drilling-dense region. Endocrinology 155(3):897-907. https://doi.org/10.1210/en.2013-1697

Kersting J, Duscha V, Schleich J, Keramidas K (2015) The impact of shale gas on the costs of climate policy. Project No. (FKZ) 371341 103, Januar 2015. https://www.umweltbundesamt.de/ sites/default/files/medien/378/publikationen/climate_chang e_03_2015_the_impact_of_shale_gas_1.pdf. Accessed 14 Jan 2020

King GE, Durham D (2015) Environmental aspects of hydraulic fracturing: what are the facts? In: Drogos DL (ed) Hydraulic fracturing: environmental issues. ACS symposium series, vol 1216. American Chemical Society, Washington, D.C., pp 1-44. https ://doi.org/10.1021/bk-2015-1216.ch001
Kondash AJ, Lauer NE, Vengosh A (2018) The intensification of the water footprint of hydraulic fracturing. Sci Adv 4(8):82. https:// doi.org/10.1126/sciadv.aar5982

Kurose S (2014) Requiring the use of tracers in hydraulic fracturing fluid to trace alleged contamination. Sustain Dev Law Policy 14(3):43, 54. https://digitalcommons.wcl.american.edu/cgi/viewc ontent.cgi $?$ article $=1556 \&$ context $=$ sdlp. Accessed 14 Jan 2020

LAI (Länderausschuß für Immissionsschutz) (1992) Krebsrisiko durch Luftverunreinigungen. Hrsg.: Ministerium für Umwelt, Raumordnung und Landwirtschaft des Landes Nordrhein-Westfalen, Düsseldorf

LAI (Länderausschuss für Immissionsschutz) (1997) Bewertung von Toluol- und Xylol-Immissionen. LAI-Schriftenreihe, Band 16. Berlin, Erich Schmidt Verlag

LAI (Länderausschuss für Immissionsschutz) (2004) Bewertung von Schadstoffen, für die keine Immissionswerte festgelegt sindOrientierungswerte für die Sonderfallprüfung und für die Anlagenüberwachung sowie Zielwerte für die langfristige Luftreinhalteplanung unter besonderer Berücksichtigung der Beurteilung krebserzeugender Luftschadstoffe. 21. September 2004

Lanzoni A, Castoldi AF, Kass GEN et al (2019) Advancing human health risk assessment. EFSA J 17(S1):e170712. https://doi. org/10.2903/j.efsa.2019.e170712

LAWA (German Working Group on water issues of the Federal States and the Federal Government) (2017) Derivation of insignificant threshold values for the ground water. Updated and revised version 2016. Published by Länderarbeitsgemeinschaft Wasser (LAWA), January 2017. https://www.lawa.de/documents/gfsbericht_en_2_1552307510.pdf. Accessed 13 Jan 2020

LBEG (Niedersächsisches Landesamt für Bergbau, Energie und Geologie) (2016) Immissionsmessungen im Landkreis Rotenburg (Wümme): Untersuchungsergebnisse (2016). http://www.lbeg. niedersachsen.de/startseite/bergbau/schadstoffmessungen/immis sionsmessungen_im_landkreis_rotenburg_wuemme_untersuchu ngsergebnisse_2016/immissionsmessungen-im-landkreis-roten burg-wuemme-untersuchungsergebnisse-2016-146668.html. Accessed 14 Jan 2020

LBEG (2019a) https://www.lbeg.niedersachsen.de/live/search.php, search term „Lagerstättenwasser“. Accessed 13 Jan 2020

LBEG (Niedersächsisches Landesamt für Bergbau, Energie und Geologie) (2019b) Liste der Fracs in Niedersachsen (Erdgas- und Geothermiebohrungen) Stand: 12.09.2019. https://www.lbeg.niede rsachsen.de/bergbau/genehmigungsverfahren/hydraulische_bohrl ochbehandlung/hydraulische-bohrlochbehandlung-110656.html. Accessed 13 Jan 2020

Leiming L, Al-Muntasheri GA, Liang F (2016) A review of crosslinked fracturing fluids prepared with produced water. Petroleum 2(4):313-323. https://doi.org/10.1016/j.petlm.2016.10.001

Lester Y, Ferrer I, Thurman EM et al (2015) Characterization of hydraulic fracturing flowback water in Colorado: implications for water treatment. Sci Total Environ 512-513:637-644. https ://doi.org/10.1016/j.scitotenv.2015.01.043

Lilienblum W, Wollin KM (2019) Grenzwerte, Richtwerte, Empfehlungen. In: Marquardt H, Schäfer SG, Barth H (Hrsg.): Toxikologie. 4., vollständig überarbeitete und erweiterte Auflage 2019, Wissenschaftliche Verlagsgesellschaft Stuttgart:1284-1357

Lilienblum W, Dekant W, Foth H et al (2008) 2008) Alternative methods to safety studies in experimental animals: role in the risk assessment of chemicals under the new European Chemicals Legislation (REACH. Arch Toxicol 82(4):211-236. https://doi. org/10.1007/s00204-008-0279-9

Litovitz A, Curtright A, Abramzon S et al (2013) Estimation of regional air-quality damages from Marcellus Shale natural gas extraction in Pennsylvania. Environ Res Lett 8(014017):8. https ://doi.org/10.1088/1748-9326/8/1/014017 
LK Rotenburg (Wümme) (2017) Untersuchungsergebnisse des Landkreises Rotenburg (Wümme) zu einer Häufung von hämatologischen Krebserkrankungen bei Männern in der Samtgemeinde Bothel; April 2017. http://www.krebsregister-niedersachsen.de/ dateien/Sonderauswertungen/bericht_ergebnisse_befragung_sg_ bothel_27.4.2017.pdf. Accessed 14 Jan 2020

Llewellyn GT, Dorman F, Westland JL et al (2015) Evaluating a groundwater supply contamination incident attributed to Marcellus Shale gas development. Proc Natl Acad Sci USA 112(20):6325-6330. https://doi.org/10.1073/pnas.1420279112

Luek JL, Gonsior M (2017) Organic compounds in hydraulic fracturing fluids and wastewaters: a review. Water Res 123:536-548. https ://doi.org/10.1016/j.watres.2017.07.012

Ma ZQ, Sneeringer KC, Liu L, Kuller LH (2016) Time series evaluation of birth defects in areas with and without unconventional natural gas development. J Epidemiol Public Health Rev 1:4. https://doi.org/10.16966/2471-8211.107

Macey GP, Breech R, Chernaik M et al (2014) Air concentrations of volatile compounds near oil and gas production: a communitybased exploratory study. Environ Health 13:82. https://doi. org/10.1186/1476-069X-13-82

McIntosh JC, Hendry MJ, Ballentine C et al (2019) A critical review of state-of-the-art and emerging approaches to identify frackingderived gases and associated contaminants in aquifers. Environ Sci Technol 53(3):1063-1077. https://doi.org/10.1021/acs. est. 8 b05807

McKenzie LM, Witter RZ, Newman LS, Adgate JL (2012) Human health risk assessment of air emissions from development of unconventional natural gas resources. Sci Total Environ 424:7987. https://doi.org/10.1016/j.scitotenv.2012.02.018

McKenzie LM, Guo R, Witter RZ et al (2014) Birth outcomes and maternal residential proximity to natural gas development in rural Colorado. Environ Health Perspect 122(4):412-417. https ://doi.org/10.1289/ehp.1306722

McKenzie LM, Allshouse WB, Byers TE et al (2017) Childhood hematologic cancer and residential proximity to oil and gas development. PLoS One 12(2):e0170423. https://doi.org/10.1371/journ al.pone. 0170423

McKenzie LM, Allshouse W, Daniels S (2019) Congenital heart defects and intensity of oil and gas well site activities in early pregnancy. Environ Int 132:104949. https://doi.org/10.1016/j.envin t.2019.104949

McLaughlin MC, Borch T, Blotevogel J (2016) Spills of hydraulic fracturing chemicals on agricultural topsoil: biodegradation, sorption, and co-contaminant interactions. Environ Sci Technol 50(11):6071-6078. https://doi.org/10.1021/acs.est.6b00240

McMullin TS, Bamber AM, Bon D et al (2018) Exposures and health risks from volatile organic compounds in communities located near oil and gas exploration and production activities in Colorado (USA). Int J Environ Res Public Health 15(7):E1500. https://doi. org/10.3390/ijerph 15071500

Meiners HG (2012) Fracking in unkonventionellen Erdgas-Lagerstätten in Nordrhein-Westfalen. Gutachten mit Risikostudie zur Exploration und Gewinnung von Erdgas aus unkonventionellen Lagerstätten in Nordrhein-Westfalen (NRW) und deren Auswirkungen auf den Naturhaushalt insbesondere die öffentliche Trinkwasserversorgung. Auftraggeber: Ministerium für Klimaschutz, Umwelt, Landwirtschaft, Natur- und Verbraucherschutz des Landes Nordrhein-Westfalen in Abstimmung mit: Ministerium für Wirtschaft, Energie, Industrie, Mittelstand und Handwerk des Landes Nordrhein-Westfalen, Kurzfassung. https://www.umwel t.nrw.de/fileadmin/redaktion/PDFs/umwelt/gutachten_frack ing_nrw_2012.pdf. Accessed 14 Jan 2020

Meiners HG, Denneborg M, Müller F et al (2012a) Umweltauswirkungen von Fracking bei der Aufsuchung und Gewinnung von Erdgas aus unkonventionellen Lagerstätten-Risikobewertung,
Handlungsempfehlungen und Evaluierung bestehender rechtlicher Regelungen und Verwaltungsstrukturen; Gutachten im Auftrag des Umweltbundesamtes, FKZ 371123299, DessauRoßlau. https://www.umweltbundesamt.de/sites/default/files/ medien/461/publikationen/4346.pdf. Accessed 14 Jan 2020

Meiners HG, Denneborg M, Müller F et al (2012b) Environmental impacts of hydraulic fracturing related to exploration and exploitation of unconventional natural gas deposits-risk assessment, recommendations for action and evaluation of relevant existing legal provisions and administrative structures. Short version, under commission to the Federal Environment Agency (UBA). https://www.umweltbundesamt.de/sites/default/files/medien/461/ publikationen/4346-1.pdf. Accessed 14 Jan 2020

Montgomery C (2013) Fracturing fluid components. In: Bunder A, McLennon J, Jeffrey R (eds) Effective and sustainable hydraulic fracturing. InTech, pp 25-45. https://doi.org/10.5772/56422 . http://www.intechopen.com/books/effective-and-sustainabl e-hydraulic-fracturing/fracturing-fluid-components. Accessed 14 Jan 2020

Muehlenbachs K (2011) Identifying the sources of fugitive methane associated with shale gas development. Resources For the Future, Washington, DC

National Research Council (NRC) (1983) Risk assessment in the federal government. Managing the process. National Academy Press, Washington, DC. https://www.epa.gov/fera/nrc-risk-asses sment-paradigm. Accessed 14 Jan 2020

National Research Council (NRC) (2009) Science and Decisions: Advancing Risk Assessment. The National Academies Press 500 Fifth Street, NW Box 285 Washington, DC 20055. https://www. ncbi.nlm.nih.gov/books/NBK214630/pdf/Bookshelf_NBK21 4630.pdf. Accessed 14 Jan 2020

Nicot JP, Scanlon BR (2012) Water use for Shale-gas production in Texas, US. Environ Sci Technol 46(6):3580-3586. https://doi. org/10.1021/es204602t

Nienburg LK (2017) Krebsclusteruntersuchung in Rodewald: Bisher lassen sich keine Zusammenhänge finden. Meldung vom 29.09.2017. https://www.lk-nienburg.de/portal/meldungen/ krebsclusteruntersuchung-in-rodewald-bisher-lassen-sich-keine -zusammenhaenge-finden-901003921-21500.html. Accessed 14 Jan 2020

NYSDEC (New York State Department of Environmental Conservation) (2011) Revised draft supplemental generic environmental impact statement (SGEIS) on the oil, gas and solution mining regulatory program: Well permit issuance for horizontal drilling and high-volume hydraulic fracturing to develop the Marcellus shale and other low-permeability gas reservoirs. Albany, NY. http://www.dec.ny.gov/energy/75370.html. Accessed 14 Jan 2020

OECD (Organisation for Economic Co-operation and Development) (2018) Considerations for assessing the risks of combined exposure to multiple chemicals, series on testing and assessment No. 296. Environment, Health and Safety Division, Environment Directorate. ENV/JM/MONO(2018)37. https://www. oecd.org/chemicalsafety/risk-assessment/considerations-forassessing-the-risks-of-combined-exposure-to-multiple-chemi cals.pdf. Accessed 14 Jan 2020

Oetjen K, Blotevogel J, Borch T et al (2018) Simulation of a hydraulic fracturing wastewater surface spill on agricultural soil. Sci Total Environ 645:229-234. https://doi.org/10.1016/j.scito tenv.2018.07.043

Ontario Government (2006) Technical support document for Ontario drinking-water quality standards, objectives and guidelines. June 2003, revised June 2006. PIBS 4449e0. http://www.ontla.on.ca/ library/repository/mon/14000/263450.pdf. Accessed 14 Jan 2020

Osborn SG, Vengosh A, Warner NR, Jackson RB (2011) Methane contamination of drinking water accompanying gas-well drilling and 
hydraulic fracturing. Proc Natl Acad Sci USA 108(20):81728176. https://doi.org/10.1073/pnas.1100682108

Parker KM, Zeng T, Harkness J et al (2014) Enhanced formation of disinfection byproducts in shale gas wastewater-impacted drinking water supplies. Environ Sci Technol 48(19):11161-11169. https://doi.org/10.1021/es5028184

Paulik LB, Donald CE, Smith BW (2016) Emissions of polycyclic aromatic hydrocarbons from natural gas extraction into air. Environ Sci Technol 50(14):7921-7929. https://doi.org/10.1021/acs. est.6b02762

Peng L, Meyerhoefer C, Chou SY (2018) The health implications of unconventional natural gas development in Pennsylvania. Health Econ 27(6):956-983. https://doi.org/10.1002/hec.3649

Rabinowitz PM, Slizovskiy IB, Lamers V et al (2015) Proximity to natural gas wells and reported health status: results of a household survey in Washington County. Pennsylvania. Environ Health Perspect 123(1):21-26. https://doi.org/10.1289/ehp.1307732

Rasmussen SG, Ogburn EL, McCormack M et al (2016) Association between unconventional natural gas development in the Marcellus Shale and asthma exacerbations. JAMA Intern Med 176(9):1334-1343. https://doi.org/10.1001/jamaintern med.2016.2436

Reagan MT, Moridis GJ, Keen ND, Johnson JN (2015) Numerical simulation of the environmental impact of hydraulic fracturing of tight/shale gas reservoirs on near-surface groundwater: background, base cases, shallow reservoirs, short-term gas, and water transport. Water Resour Res 51(4):2543-2573

Regulation (EC) No 1272/2008 of the European Parliament and of the Council of 16 December 2008 on classification, labelling and packaging of substances and mixtures, amending and repealing Directives 67/548/EEC and 1999/45/EC, and amending Regulation (EC) No 1907/2006. English version: https://eur-lex.europ a.eu/legal-content/EN/TXT/PDF/?uri=CELEX:32008R1272 $\&$ from $=\mathrm{EN}$

Rich AL, Orimoloye HT (2016) Elevated atmospheric levels of benzene and benzene-related compounds from unconventional shale extraction and processing: human health concern for residential communities. Environ Health Insights 10:75-82. https://doi. org/10.4137/EHI.S33314

Robinson AL (2014) Air pollution emissions from shale gas development and production. In: Coussens C and Martinez RM (Rapporteurs): IOM (Institute of Medicine). 2014. Health impact assessment of shale gas extraction: Workshop summary. Washington, DC: The National Academies Press. https://www.ncbi.nlm.nih. gov/books/NBK201897/. Accessed 14 Jan 2020

Saba T, Mohsen F, Garry M et al (2012) White paper: Methanol use in hydraulic fracturing fluids. Exponent, Maynard, MA. http:// www.methanol.org/wp-content/uploads/2016/06/White-Paper -Methanol-Use-in-Hydraulic-Fracturing-Jan-11.pdf. Accessed 14 Jan 2020

Saberi P, Propert KJ, Powers M et al (2014) Field survey of health perception and complaints of Pennsylvania residents in the Marcellus Shale region. Int J Environ Res Public Health 11(6):6517-6527

Saunders PJ, McCoy D, Goldstein R et al (2018) A review of the public health impacts of unconventional natural gas development. Environ Geochem Health 40(1):1-57. https://doi.org/10.1007/ s10653-016-9898-x

SCHEER (Scientific Committee on Health, Environmental and Emerging Risks) (2018) Opinion on the public health impacts and risks resulting from onshore hydrocarbon exploration and production in the EU, 30 November 2018

Schloemer S, Oest J, Illing CJ et al (2018) Spatial distribution and temporal variation of methane, ethane and propane background levels in shallow aquifers-a case study from Lower
Saxony (Germany). J Hydrol Region Stud 19:57-79. https://doi. org/10.1016/j.ejrh.2018.07.002

Schlumberger (2017) ClearFRAC polymer-free fracturing fluids. https ://www.slb.com/completions/stimulation/fracturing-services/ clearfrac

Schneider J, Rieche R, Hammerschmidt U, Fleer M (2018) Stoffgehalte in Böden und Sedimenten im Umfeld aktiver Erdgasförderstellen in Niedersachsen. Niedersächsisches Landesamt für Bergbau, Energie und Geologie, 11.01.2018. http://www.lbeg.niede rsachsen.de/startseite/bergbau/schadstoffmessungen/untersuchu ngen_im_umfeld_von_erdgasfoerderplaetzen/untersuchungenim-umfeld-von-erdgasfoerderplaetzen-135742.html

Sherwood OA, Rogers JD, Lackey G et al (2016) Groundwater methane in relation to oil and gas development and shallow coal seams in the Denver-Julesburg Basin of Colorado. Proc Natl Acad Sci USA 113(30):8391-8396. https://doi.org/10.1073/pnas.15232 67113

Shrestha N, Chilkoor G, Wilder J et al (2017) Potential water resource impacts of hydraulic fracturing from unconventional oil production in the Bakken shale. Water Res 108:1-24. https://doi. org/10.1016/j.watres.2016.11.006

Siegel DI, Azzolina NA, Smith BJ et al (2015) Methane concentrations in water wells unrelated to proximity to existing oil and gas wells in northeastern Pennsylvania. Environ Sci Technol 49(7):41064112. https://doi.org/10.1021/es505775c

Smith MB, Montgomery C (2015) Hydraulic fracturing. CRC Press, Boca Raton

SRU (Sachverständigenrat für Umweltfragen) (2013) Fracking zur Schiefergasgewinnung. Ein Beitrag zur energie- und umweltpolitischen Bewertung. Stellungnahme Nr. 18. https://www. umweltrat.de/SharedDocs/Downloads/DE/04_Stellungna hmen/2012_2016/2013_05_AS_18_Fracking.pdf?_blob=publi cationFile. Accessed 14 Jan 2020

Stacy SL, Brink LL, Larkin JC et al (2015) Perinatal outcomes and unconventional natural gas operations in Southwest Pennsylvania. PLoS One 10(6):e0126425. https://doi.org/10.1371/journ al.pone. 0126425

States S, Cyprych G, Stoner M et al (2013) Marcellus Shale drilling and brominated THMs in Pittsburgh, Pa, drinking water. J Am Water Works Ass 105(8):E432-E448. https://doi.org/10.5942/ jawwa.2013.105.0093

Steinzor N, Subra W, Sumi L (2013) Investigating links between shale gas development and health impacts through a community survey project in Pennsylvania. New Solut 23(1):55-83. https://doi. org/10.2190/NS.23.1.e

Stigler Granados P, Hildenbrand ZL, Mata C (2019) Attitudes, perceptions, and geospatial analysis of water quality and individual health status in a high-fracking region. Water 11(8):1633. https ://doi.org/10.3390/w11081633

Stringfellow WT, Domen JK, Camarillo MK et al (2014) Physical, chemical, and biological characteristics of compounds used in hydraulic fracturing. J Hazard Mater 275:37-54. https://doi. org/10.1016/j.jhazmat.2014.04.040

Stringfellow WT, Camarillo MK, Domen JK et al (2017a) Identifying chemicals of concern in hydraulic fracturing fluids used for oil production. Environ Pollut 220:413-420. https://doi. org/10.1016/j.envpol.2016.09.082

Stringfellow WT, Camarillo MK, Domen JK, Shonkoff SBC (2017b) Comparison of chemical-use between hydraulic fracturing, acidizing, and routine oil and gas development. PLoS One 12(4):e0175344. https://doi.org/10.1371/journal.pone.0175344

Sun Y, Wang D, Tsang DCW et al (2019) A critical review of risks, characteristics, and treatment strategies for potentially toxic elements in wastewater from shale gas extraction. Environ Int 125:452-469. https://doi.org/10.1016/j.envint.2019.02.019 
TCEQ (Texas Commission on Environmental Quality) (2011) Texas Air Monitoring Information. https://www.tceq.texas.gov/airqu ality/monops/air-mon. Accessed 14 Jan 2020

Tustin AW, Hirsch AG, Rasmussen SG et al (2017) Associations between unconventional natural gas development and nasal and sinus, migraine headache, and fatigue symptoms in Pennsylvania. Environ Health Perspect 125(2):189-197. https://doi. org/10.1289/EHP281

TÜV Hannover (1988) Emissionsmessungen an einer Kaltgasfackel bei der BEB Erdgas Erdöl Schlaher Damm 3, 2839 Barenburg, 07.09.1988

Tyndall Centre for Climate Change Research (2011) Shale gas: a provisional assessment of climate change and environmental impacts. Manchester, January 2011 (Final). https://www.research.manch ester.ac.uk/portal/files/36728313/FULL_TEXT.PDF. Accessed 14 Jan 2020

UBA (Umweltbundesamt) (2017) Methan-Emissionen. http://www. umweltbundesamt.de/daten/klimawandel/treibhausgas-emiss ionen-in-deutschland/methan-emissionen. Accessed 14 Jan 2020

U.S. DOI (U.S. Department of the Interior, Office of Surface Mining) (2001) Technical measures for the investigation and mitigation of fugitive methane hazards in areas of coal mining. https://www. osmre.gov/resources/blasting/docs/MineGasesDust/Methane.pdf. Accessed 14 Jan 2020

U.S. EIA (U.S. Energy Information Administration) (2017) Today in energy. China leads the growth in projected global natural gas consumption. October 25, 2017. https://www.eia.gov/todayinene rgy/detail.php?id=33472. Accessed 14 Jan 2020

U.S. EIA (2019) https://www.eia.gov/tools/faqs/faq.php?id=907\&t=8. Accessed 13 Jan 2020

U.S. EPA (US Environmental Protection Agency) (2009) Recent findings in EPA's lead scavengers evaluation. https://cfpub.epa. gov/si/si_public_record_report.cfm?Lab=NRMRL\&TIMST ype $=\&$ count $=10000 \&$ dirEntryId $=189405 \&$ searchAll $=\&$ showC riteria $=2 \&$ simpleSearch $=0 \&$ startIndex $=20001$. Accessed 14 Jan 2020

U.S. EPA (U.S. Environmental Protection Agency) (2011) Plan to study the potential impacts of hydraulic fracturing on drinking water resources. Office of Research and Development, US Environmental Protection Agency; Washington, D.C., EPA/600/R-11/122. https://www.epa.gov/sites/production/files/documents/hf_study _plan_110211_final_508.pdf. Accessed 14 Jan 2020

U.S. EPA (U.S. Environmental Protection Agency) (2012) 2012 Final rules for oil and natural gas industry. https://www.epa.gov/contr olling-air-pollution-oil-and-natural-gas-industry/2012-final-rules -oil-and-natural-gas-industry. Accessed 14 Jan 2020

U.S. EPA (U.S. Environmental Protection Agency) (2014) Permitting guidance for oil and gas hydraulic fracturing activities using diesel fuels: underground injection control program guidance \#84. EPA 816-R-14-001. https://www.epa.gov/sites/production /files/2015-05/documents/revised_dfhf_guid_816r14001.pdf. Accessed 14 Jan 2020

U.S. EPA (U.S. Environmental Protection Agency) (2015) Analysis of hydraulic fracturing fluid data from the FracFocus chemical disclosure registry 1.0: Project database. EPA Technical Report, EPA/601/R-14/003. https://www.epa.gov/sites/production/files /2015-03/documents/fracfocus_analysis_report_and_appendices _final_032015_508_0.pdf. Accessed 15 Jan 2020

U.S. EPA (U.S. Environmental Protection Agency) (2016a) Hydraulic fracturing for oil and gas: impacts from the hydraulic fracturing water cycle on drinking water resources in the United States (Final Report). U.S. Environmental Protection Agency, Washington, DC, EPA/600/R-16/236F. https://cfpub.epa.gov/ncea/ hfstudy/recordisplay.cfm?deid=332990. Accessed 15 Jan 2020

U.S. EPA (U.S. Environmental Protection Agency) (2016b) Unconventional oil and gas extraction effluent guidelines. https://www.epa. gov/eg/unconventional-oil-and-gas-extraction-effluent-guidelines . Accessed 15 Jan 2020

U.S. EPA (U.S. Environmental Protection Agency) (2017) Inventory of U.S. greenhouse gas emissions and sinks 1990-2015. https:// www.epa.gov/ghgemissions/inventory-us-greenhouse-gas-emiss ions-and-sinks. Accessed 15 Jan 2020

U.S. EPA (U.S. Environmental Protection Agency) (2019) Inventory of U.S. Greenhouse Gas Emissions and Sinks 1990-2017. https:// www.epa.gov/ghgemissions/inventory-us-greenhouse-gas-emiss ions-and-sinks. Accessed 15 Jan 2020

U.S. EPA IRIS (United States Environmental Protection Agency Integrated Risk Information System) (2020) https://www.epa.gov/ iris. Accessed 15 Jan 2020

U.S. EPA IRIS (U.S. Environmental Protection Agency Integrated Risk Information System) (2013) Toxicological Review of Methanol (Non-Cancer) (CAS No. 67-56-1). https://cfpub.epa.gov/ncea/ iris2/chemicalLanding.cfm?\&substance_nmbr=305. Accessed 15 Jan 2020

Vandecasteele I, Marí Rivero I, Sala S et al (2015) Impact of shale gas development on water resources: a case study in Northern Poland. Environ Manag 55(6):1285-1299. https://doi. org/10.1007/s00267-015-0454-8

Vengosh A, Jackson RB, Warner N et al (2014) A critical review of the risks to water resources from unconventional shale gas development and hydraulic fracturing in the United States. Environ Sci Technol 48(15):8334-8348. https://doi.org/10.1021/es405118y

Vidic RD, Brantley SL, Vandenbossche JM et al (2013) Impact of shale gas development on regional water quality. Science 340(6134):1235009. https://doi.org/10.1126/science.1235009

Vinciguerra T, Yao S, Dadzie J et al (2015) Regional air quality impacts of hydraulic fracturing and shale natural gas activity: evidence from ambient VOC observations. Atmos Environ 110:144-150. https://doi.org/10.1016/j.atmosenv.2015.03.056

Walker Whitworth K, Kaye Marshall A, Symanski E (2018) Drilling and production activity related to unconventional gas development and severity of preterm birth. Environ Health Perspect 126(3):037006. https://doi.org/10.1289/EHP2622

Wang YD, Fan HF (2015) Research on and application of clean fracturing fluids in coal-bed methane. Adv Mater Res 10921093:212-215. https://doi.org/10.4028/www.scientific.net/ AMR.1092-1093.212

Warner NR, Christie CA, Jackson RB, Vengosh A (2013) Impacts of shale gas wastewater disposal on water quality in Western Pennsylvania. Environ Sci Technol 47(20):11849-11857. https://doi. org/10.1021/es402165b

Wattenberg EV, Bielicki JM, Suchomel AE et al (2015) Assessment of the acute and chronic health hazards of hydraulic fracturing fluids. J Occup Environ Hyg 12(9):611-624. https://doi. org/10.1080/15459624.2015.1029612

Weaver JW, Xu J, Mravik SC (2016) Scenario analysis of the impact on drinking water intakes from bromide in the discharge of treated oil and gas wastewater. J Environ Eng 142(1):0401505010401505014. https://doi.org/10.1061/(ASCE)EE.19437870.0000968

Webb E, Bushkin-Bedient S, Cheng A et al (2014) Developmental and reproductive effects of chemicals associated with unconventional oil and natural gas operations. Rev Environ Health 29(4):307318. https://doi.org/10.1515/reveh-2014-0057

Weinberger B, Greiner LH, Walleigh L, Brown D (2017) Health symptoms in residents living near shale gas activity: a retrospective record review from the Environmental Health Project. Prev Med Rep 8:112-115. https://doi.org/10.1016/j.pmedr.2017.09.002

Wendt Hess J, Bachler G, Momin F, Sexton K (2019) Assessing agreement in exposure classification between proximity-based metrics and air monitoring data in epidemiology studies of 
unconventional resource development. Int J Environ Res Public Health 16(17):E3055. https://doi.org/10.3390/ijerph16173055

Werner AK, Vink S, Watt K, Jagals P (2015) Environmental health impacts of unconventional natural gas development: a review of the current strength of evidence. Sci Total Environ 505:11271141. https://doi.org/10.1016/j.scitotenv.2014.10.084

Werner AK, Watt K, Cameron CM et al (2016) All-age hospitalization rates in coal seam gas areas in Queensland, Australia, 19952011. BMC Public Health 16:125. https://doi.org/10.1186/s1288 9-016-2787-5

Whitworth KW, Marshall AK, Symanski E (2017) Maternal residential proximity to unconventional gas development and perinatal outcomes among a diverse urban population in Texas. PLoS One 12(7):e0180966. https://doi.org/10.1371/journal.pone.0180966

WHO (World Health Organization) (2009) Bromide in drinking-water. Background document for development of WHO Guidelines for Drinking-water Quality. WHO/HSE/WSH/09.01/6. http://www. who.int/water_sanitation_health/dwq/chemicals/Fourth_Editi on_Bromide_Final_January_2010.pdf. Accessed 15 Jan 2020

WHO (World Health Organization) (2017) Guidelines for drinkingwater quality - 4th edition. https://apps.who.int/iris/bitstream/ handle/10665/254637/9789241549950-eng.pdf;jsessionid $=205918$ A9EABFE1414033 ABC32C5F5B 77? sequence $=1$. Accessed 15 Jan 2020

Wollin KM (2016a) Toxikologische Bewertung von Brauchwasserproben aus 27386 Bellen. Vortrag, Landes-Arbeitsgruppe EKNAuswertungen LK Rotenburg (Wümme), Hannover, 13.12.2016. https://doi.org/10.13140/RG.2.2.15154.35525

Wollin KM (2016b) Toxikologische Bewertung von Umweltgutachten zum ehemaligen BEB-Betriebsplatz Suderbruch in 31637 Rodewald-Neudorf und angrenzender Bereiche. Niedersächsisches Landesgesundheitsamt (NLGA) (Hrsg.), Hannover, 14.03.2016. https://doi.org/10.13140/rg.2.2.35259.31521. http://www.nlga. niedersachsen.de/download/114094/

Wollin KM, Illing HP (2014) Limit value setting in different areas of regulatory toxicology. In: Reichl FX, Schwenk M (eds) regulatory toxicology. Springer, Berlin Heidelberg, pp 649-659

Wollin KM, Nohr K, Huppmann R et al (2015a) Investigation of domestic wells in the vicinity of tight gas exploitation in Lower Saxony. In: 15th EuCheMS international conference 20-24 Sept 2015, Leipzig, Germany. https://doi.org/10.13140/rg.2.1.2315.4165

Wollin KM, Nohr K, Huppmann R et al (2015b) Untersuchung von Hausbrunnen in der Nachbarschaft von Erdgasförderaktivitäten. Das Gesundheitswesen 16:P41. https://doi. org/10.1055/s-0035-1546943

Wollin KM, Strotkötter U, Zielke S et al (2017a) Are the environmental impacts of an abandoned petroleum industry site a health risk for the adjacent residents? Naunyn-Schmiedeberg's Arch Pharmacol 390(Suppl 1):S47. https://doi.org/10.13140/RG.2.2.31649.20326

Wollin KM, Strotkötter U, Zielke S et al (2017b) Risk assessment of environmental impacts of a former petroleum industry site in relation to the residential population of the neighbourhood. Das Gesundheitswesen 79(04):299-374. https://doi. org/10.1055/s-0037-1602113

WGS84 (World Geodetic System) (1984) https://www.nga.mil/Produ ctsServices/GeodesyandGeophysics/Pages/WorldGeodeticSy stem.aspx. Accessed 14 Jan 2020

Wright R, Muma RD (2018) High-volume hydraulic fracturing and human health outcomes: a scoping review. J Occup Environ Med 60(5):424-429. https://doi.org/10.1097/JOM.0000000000001278

Xu X, Zhang X, Carrillo G et al (2019) A systematic assessment of carcinogenicity of chemicals in hydraulic-fracturing fluids and flowback water. Environ Pollut 251:128-136. https://doi org/10.1016/j.envpol.2019.04.016

Yost EE, Stanek J, DeWoskin RS, Burgoon LD (2016) Overview of chronic oral toxicity values for chemicals present in hydraulic fracturing fluids, flowback, and produced waters. Environ Sci Technol 50(9):4788-4797. https://doi.org/10.1021/acs.est.5b046 45

Yost EE, Stanek J, Burgoon LD (2017) A decision analysis framework for estimating the potential hazards for drinking water resources of chemicals used in hydraulic fracturing fluids. Sci Total Environ 574:1544-1558. https://doi.org/10.1016/j.scito tenv.2016.08.167

Zielinska B, Campbell D, Samburova V (2014) Impact of emissions from natural gas production facilities on ambient air quality in the Barnett Shale area: a pilot study. J Air Waste Manag Assoc 64(12):1369-1383

Ziemkiewicz PF (2013) Characterization of liquid waste streams from shale gas development. AGH Drill Oil Gas 30(1):297-309. https ://doi.org/10.7494/drill.2013.30.1.297

Ziemkiewicz PF, Thomas He Y (2015) Evolution of water chemistry during Marcellus Shale gas development: a case study in West Virginia. Chemosphere 134:224-231. https://doi.org/10.1016/j. chemosphere.2015.04.040

ZUS LLG (Zentrale Unterstützungsstelle Luftreinhaltung, Lärm und Gefahrstoffe) Staatliches Gewerbeaufsichtsamt Hildesheim (2016) Immissionsprognose für den Betrieb einer Kaltgasfackel in Rodewald OT Neudorf, 18.05.2016

Publisher's Note Springer Nature remains neutral with regard to jurisdictional claims in published maps and institutional affiliations.

\section{Affiliations}

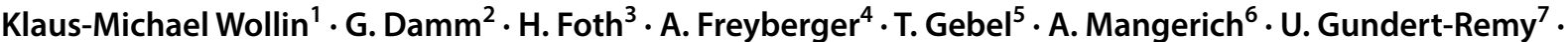 F. Partosch ${ }^{8} \cdot$ C. Röhl ${ }^{9} \cdot$ T. Schupp ${ }^{10} \cdot$ Jan G. Hengstler ${ }^{11}$}

1 Formerly Public Health Agency of Lower Saxony, Hannover, Germany

2 Department of Hepatobiliary Surgery and Visceral Transplantation, University Hospital, Leipzig University, Leipzig, Germany

3 Institute of Environmental Toxicology, University of Halle, Halle/Saale, Germany
4 Research and Development, Translational Sciences-Toxicology, Bayer AG, Wuppertal, Germany

5 Federal Institute for Occupational Safety and Health, Dortmund, Germany

6 Molecular Toxicology, Department of Biology, University of Konstanz, Constance, Germany

7 Institute for Clinical Pharmacology and Toxicology, Charité, Universitätsmedizin Berlin, Berlin, Germany 
8 Institute for Occupational, Social and Environmental Medicine, University Medical Center, Göttingen, Germany

9 Department of Environmental Health Protection, Schleswig-Holstein State Agency for Social Services, Kiel, Germany
10 Chemical Engineering, University of Applied Science Muenster, Steinfurt, Germany

11 Leibniz Research Centre for Working Environment and Human Factors (IfADo), University of Dortmund, Dortmund, Germany 